\title{
WPLYW STAROŻYTNEJ SCHEMATYZACJI MNEMOTECHNICZNEJ NA KARTOGRAFIĘ ŚREDNIOWIECZNĄ I WCZESNONOWOŻYTNĄ
}

Kwestia związków antycznej techniki zapamiętywania z geografią starożytną oraz ze średniowieczną i wczesnonowożytną kartografią jest zagadnieniem, które funkcjonuje jako swego rodzaju produkt uboczny badań historycznych w zakresie geo- i kartografii. Jest bowiem rzeczą oczywistą, że pamięć i zapamiętywanie są integralną częścią nie tylko dociekań historycznych, lecz także geografii i kartografii jako takich. Ostatecznie ich produkt finalny czyli mapa jest przecież obrazem świata, a obraz często wpisuje się w ludzką pamięć łatwiej niż słowo. W kontekście rozważań nad rolą mnemotechniki w historii geografii i kartografii z konieczności trzeba przywołać, choćby marginalnie, kilka wątków pobocznych a w tym kontekście ważnych, ponieważ stanowią one istotne dopełnienie przedmiotowych analiz. Rozważana tutaj mnemotechnika ma swoją makro- i mikroskalę. Zapamiętuje się bowiem $\mathrm{z}$ jednej strony obraz Ziemi jako całości, z drugiej zaś określone „detale terytorialne”. Zarówno makro- jak i mikroelementy cechuje pewna powtarzalność, która ułatwia ich zapamiętanie. Towarzyszy jej niekiedy podobieństwo do elementów ze sfery często bardzo odległej od geo- i kartografii. Ta konwencjonalność i analogiczność makro- i mikroelementów stwarza coś, co można określić mianem „mnemotechnicznego klimatu”. To istnienie tego właśnie klimatu skłania do podjęcia powyższych analiz. Trzeba jednak raz jeszcze uczciwie zastrzec, że jest to watek poboczny z punktu widzenia historii rzeczonych dyscyplin. Prologiem do tego zagadnienia będzie kilka zamieszczonych niżej uwag.

Za ojca mnemotechniki antycznej uważa się tradycyjnie poetę Symonidesa z Keos (ok. 556 - ok. 468 p.n.e.) ${ }^{1}$. Jednak pierwsze wzmianki źródłowe,

${ }^{*}$ Dr hab. Piotr Kochanek, prof. KUL - kierownik Katedry Historii Starożytnej i Bizantyńskiej w Instytucie Historii na Wydziale Nauk Humanistycznych Katolickiego Uniwersytetu Lubelskiego Jana Pawła II; e-mail: lu2005harn@yahoo.de.

${ }^{1}$ Nawiązanie to owego „ojcostwa” Symonidesa wybrzmiało ostatnio w czasie obrad ogólnopolskiej konferencji starożytniczej pt. „Meministi? Pamięć i niepamięć w świecie starożytnym, świat starożytny w pamięci i niepamięci” (Poznań, „Collegium Historicum”, 20-22 IX 2017) przynajmniej w dwóch wystąpieniach: dr hab. Krzysztofa Nareckiego (prof. KUL) i mgr Aleksandry Szokalskiej (UWr). 
które przypisują mu owo ojcostwo znajdują się dopiero w zachowanych źródła z III w. p.n.e., a mianowicie na „Marmor Parium” (ok. 264/263 p.n.e.) $)^{2}$ oraz u Kallimacha z Cyreny (ok. 310 - ok. 240 p.n.e.) $)^{3}$. Są to zatem wzmianki bardzo późne i trudno uznać je za bezspornie wiarygodne. Teza ta została jednak przejęta bez zastrzeżeń przez autorów rzymskich tej miary co Cicerona (106-43 p.n.e. $)^{4}$, Pliniusza Starszego (23-79 n.e.) ${ }^{5}$ i Kwintyliana (ok. 35 - ok. 96 n.e. $)^{6}$, i to ich autorytet uczynił ostatecznie Symonidesa ojcem starożytnej sztuki zapamiętywania. Zagadnienie to powraca co pewien czas w literaturze fachowej, często wraz ze wspomnianą przez Kallimacha opowieścią o uczcie, wydanej na cześć zwycięskiego zapaśnika, w czasie której zawalić miał się dach sali biesiadnej. Symonides ocalał, ponieważ na chwilę opuścił towarzystwo. Reszta uczestników bankietu zginęła, a ich ciała były tak zmasakrowane, że nie możny było zidentyfikować zwłok. Symonides był jednak w stanie odtworzyć z pamięci rozmieszczenie biesiadników przy stole i na tej podstawie zidentyfikowano ciała ofiar ${ }^{7}$. $\mathrm{Z}$ punktu widzenia niniejszych analiz nie jest

${ }^{2}$ Das Marmor Parium, hrsg. und erklärt von F. Jacoby, Berlin 1904, s. 16 (A 70(54), 126) i s. 114 (komentarz).

${ }^{3}$ Callimachus, Aetius fr. 64, 9-14, ed. C.A. Trypanis: Callimachus, Aetia. Iambi. Lyric poems. Hecale. Minor epic and elegiac poems. Fragments of epigrams. Fragments of uncertain location, text, translation and notes, Cambridge (Mass.) - London 1958, 46.

${ }^{4}$ Cicero, De oratore II 86, 352-353, ed. K. Kumaniecki: Cicero, Scripta quae supersunt omnia, fasc. III: De oratore, Leipzig 1969, 254, 1-19.

${ }^{5}$ Plinius Maior, Naturalis historia VII (24) 89, ed. C. Mayhoff: Plinius Secundus, Naturalis historia, vol. 2: Libri VII-XV, Lipsiae 1909, 31, 18-19.

${ }^{6}$ Quintilianus, Institutio oratoria XI 2, 11-13, ed. L. Radermacher: Quintilianus, Institutio oratoria, vol. 2, Lipsiae 1965, 316, 4-22.

${ }^{7}$ Por. U. von Wilamowitz-Moellendorff, Sapho und Simonides. Untersuchungen über griechische Lyriker, Berlin 1913, 142; L. Volkmann, Ars Memorativa, „Jahrbuch der kunsthistorischen Sammlungen in Wien” N.F. 3 (1929) 114; L.A. Post, Ancient Memory Systems, „The Classical Weekly" 25 (1932) nr 14, 106-107; H. Hajdu, Das mnemotechnische Schrifttum des Mittelalters, Budapest 1936, 14-15; W. Schmidt-Dengler, Die ,, aula memoriae” in den Konfessionen des heiligen Augustin, REAug 14 (1968) nr 1-2, 83-84; H. Blum, Die antike Mnemotechnik, Spudasmata 15, Hildesheim 1969, 41-46; W.J. Slater, Simonides' House, „Phoenix” 26 (1972) nr 3, 232-240; M. Simondon, La mémoire et l'oubli dans la pensée grecque jusqu'à la fin du Vé siècle avant J.-C. Psychologie archaïque, mythes et doctrines, Paris 1982, 181-183; S. Goldmann, Statt Totenklage Gedächtnis. Zur Erfindung der Mnemotechnik durch Simonides von Keos, „Poetica” 21 (1989) 64; F.A. Yates, Gedächtnis und Erinnern. Mnemotechnik von Aristoteles bis Shakespeare, übers. von A. Schweikhart, Weinheim 1990, 35; M. Frenschkowski, Offenbarung und Epiphanie, 2. Bd.: Die verborgene Epiphanie in Spätantike und frühen Christentum, Wissenschaftliche Untersuchungen zum Neuen Testament II/80, Tübingen 1997, 100; J.P. Small, Wax tablets of the mind. Cognitive studies of memory and literacy in classical antiquity, London 1997, 82-86; H. Weinrich, Lethe. Kunst und Kritik des Vergessens, 2. Aufl., München 1997, 21-23; A. Assmann, Erinnerungsräume. Formen und Wandlungen des kulturellen Gedächtnisses, München 1999, 35-38; A. Gormans, Geometria et ars memorativa. Studien zur Bedeutung von Kreis und Quadrat als Bestandteile mittelalterlicher Mnemonik und ihrer Wirkungsgeschichte an ausgewählten Beispielen, Doktorarbeit. Philosophische Fakultät der Rheinisch-Westfälischen Technischen Hochschule Aachen, 1999 (praca 
ważne, czy Symonides z Keos jest twórcą mnemotechniki, czy też zaszczyt ten został mu tylko przypisany przez potomnych. Ważne jest, że geneza antycznej mnemotechniki jest wiązana z zamkniętą przestrzenią sali biesiadnej. Jest to bowiem przestrzeń mierzalna, dokładnie zdeterminowana, z jasno określonymi punktami odniesienia. To w tej przestrzeni operuje sztuka zapamiętywania, ponieważ jest to przestrzeń na tzw. ludzką miarę. Człowiek potrafi ją ogarnąć wzrokiem i zachować w pamięci znajdujące się w niej szczegóły.

$\mathrm{Z}$ drugiej strony należy wziąć po uwagę pozornie tylko różny od powyższego zestaw pojęć. Chodzi mianowicie o pojęcie opisu Ziemi, czyli geografii ( $\gamma \varepsilon \omega \gamma \rho \alpha \varphi i ́ \alpha)$, oraz o pojęcie pomiaru Ziemi, czyli geometrii $(\gamma \varepsilon \omega \mu \varepsilon \tau \rho i ́ \alpha)$. Oba te terminy odnoszą się do badania powierzchni Ziemi $(\gamma \hat{\eta})$, jednak pierwsze $\mathrm{z}$ nich akcentuje aspekt opisowy tych dociekań ( $\gamma \rho \alpha ́ \varphi \omega-$ opisuję, przedstawiam, piszę), drugie natomiast aspekt matematyczny, odwołując się do pomiarów $(\mu \varepsilon \tau \rho \varepsilon ́ \omega-\text { mierzę) })^{8}$. Tymczasem w kontekście opisanej wyżej genezy mnemotechniki owe dwa pojęcia, czyli ,geografia” i ,geometria”, nie odbiegają w swym etymologicznym sensie od idei ujęcia przestrzeni w ramy tzw. ludzkiej miary. W obu jednak wypadkach geometria, a ściślej geometryzacja przestrzeni, jest ważniejsza od geografii. Z kolei obok tych dwóch pojęć należy postawić jeszcze inny, równie ważny w aspekcie etymologicznym ter-

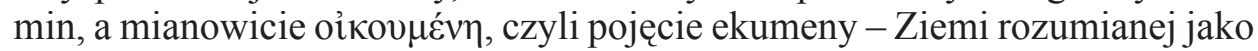
swoisty dom ludzkości, które odnosi się do tej części naszej planety, która nadaje się do zamieszkania przez ludzi. W tym sensie sala biesiadna domu i Ziemia-Dom stają się terminami bliskimi. Kluczem do ich „pokrewieństwa” jest oczywiście geometria, tworząca z nich przestrzeń, którą ludzki umysł jest w stanie racjonalnie usystematyzować i przyswoić sobie dzięki pamięci.

Ponieważ zaś Grecy z racji położenia swego kraju byli zawsze w bliskim kontakcie z morzem, zatem rodzaj symbiozy między nie nadającym się na dom morzem, żywiołem groźnym i potężnym, a ekumeną był dla nich czymś oczywistym. U Strabona (ok. 63 p.n.e. - ok. 24 n.e.) zachowała się reminiscencja tej właśnie najprawdopodobniej prastarej, panhelleńskiej idei. Stwierdza on

ta jest w całości dostępna w internecie pod adresem: http://darwin.bth.rwth-aachen.de/opus3/volltexte/2003/551/pdf/03_081pdf [data dostępu: 10 IX 2017], 20, 92-95 i 288-289; Gedächtnislehren und Gedächtniskünste in Antike und Frühmittelalter (5. Jahrhundert v. Chr. bis 9. Jahrhundert n. Chr.). Dokumentensammlung mit Übersetzung, Kommentar und Nachwort, hrsg. von J.J. Berns, unter Mitarbeit von R.G. Czapla - S. Arend, Tübingen 2003, 526-530; J.S. Bruss, Lessons from Ceos. Written and spoken word of Callimachus, w: Callimachus II, ed. by M.A. Harder - R.F. Regtuit - G.C. Walker, Hellenistica Groningiana 7, Leuven 2004, 64; G.K. Sprigath, Das Dictum des Simonides, „Poetica” 36 (2004) 265-266; P. Kochanek, Schematy ekumeny w literaturze patrystycznej w kontekście klasycznych schematów zamieszkatej Ziemi, VoxP 30 (2010) t. 55, 310-311; T. Majewski, Mnemotechnika, w: Modi memoranda. Leksykon kultury pamięci, red. M. Saryusz-Wolska - R. Traba - J. Kalicka, Warszawa 2017, 240-246.

${ }^{8}$ Por. P. Kochanek, Iluzja schematów choro- i topograficznych jako baza mnemotechnicznej portolany w starożytności, w: Tworzenie iluzji społecznej - wiedza w sferze publicznej, red. J. Szymczyk - M. Zemła - A. Jabłoński, Studia nad Wiedzą 5, Lublin 2012, 73. 
bowiem, że to morze opisuje ziemię i nadaje jej kształt ( $\dot{\eta} \theta \alpha \dot{\lambda} \alpha \sigma \sigma \alpha \gamma \varepsilon \omega \gamma \rho \alpha \varphi \varepsilon \hat{\imath}$

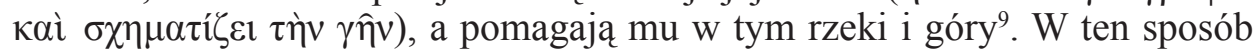

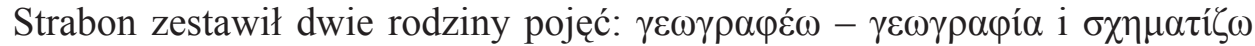
$-\sigma \chi \hat{\eta} \mu \alpha-\sigma \chi \eta \mu \alpha \tau 1 \sigma \mu o ́ s-\sigma \chi \eta \mu \alpha \tau o \gamma \rho \alpha \varphi i ́ \alpha$. Istotne rozszerzenie wprowadza ten ostatni termin oraz związana z nim grupa wyrazów pokrewnych. W konsekwencji geografia i schematyzacja są tu przedstawione jako dwa bardzo

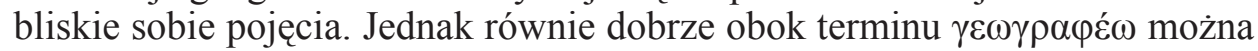
by postawić termin $\gamma \varepsilon \omega \mu \varepsilon \tau \rho \varepsilon ́ \omega$, ponieważ, jak już wspomniano, pojęcia te są sobie etymologicznie bardzo bliskie i odnoszą się do tej samej rzeczywistości. Łatwo także dostrzec związek pośredni między schematyzacją a mnemotechniką, i to zarówno w aspekcie geograficznym, jak i geometrycznym.

Powyższe uwagi wstępne ukazują istnienie pewnego systemu podstawowych pojęć, tworzących klarowne ramy dla dalszych rozważań nad mnemotechniką. Jednak chcąc rozpatrywać wpływ geografii antycznej na kartografię średniowieczną i wczesnonowożytną $\mathrm{w}$ aspekcie zapamiętywania i pamięciowego odtwarzania obrazów, należy zająć się tylko tymi zagadnieniami, które zostały de facto przejęte przez kartografię średniowieczną ${ }^{10}$. Podstawowym zaś przejęciem był schemat kuli i koła. Geneza tych schematów sięga źródłowo udokumentowanych greckich dociekań nad kształtem Ziemi jako takiej. Łączy się z nią zwykle imiona „Pitagorasa (ok. 580- ok. 510 prz. Chr.) i Parmenidesa (ok. 540 - ok. 470 prz. Chr.). Zatem przynajmniej od VI w. prz.

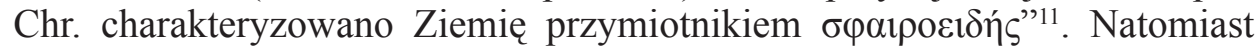
pierwszy poświadczony w źródłach model kulistej Ziemi skonstruował, jak wiadomo, Krates z Mallos (ok. 214 - ok. 150 prz. Chr.). Miał on symetrycznie podzielić Ziemię na cztery równe części za pomocą tzw. „pasów oceanicznych"12. Bodajże najlepszej pod względem technicznym rekonstrukcji tego

${ }^{9}$ Strabo, Geographica II 5, 17. C. 120, ed. A. Meineke: Strabo, Geographica, vol. 1, Lipsiae 1895, 161, 19-22. Por. Kochanek, Schematy ekumeny w literaturze patrystycznej, s. 309-310; tenże, Iluzja schematów choro- $i$ topograficznych, s. 74. W polskiej literaturze fachowej do powyższej tezy Strabona odwoływali się już wcześniej tacy badacze jak: B. Biliński, De Graeciae in Pliniana descriptio (N.H. IV 1-32) sinibus quaestiones, „Eos” 41 (1940-1946) fasc. 1, 123; J. Staszewski, Środowisko geograficzne w nauce antycznej, „Zeszyty Geograficzne Wyższej Szkoły Pedagogicznej w Gdańsku" 2 (1960) 37. W tym kontekście warto przytoczyć opinię Tadeusza Zielińskiego (14 IX 1859 - 8 V 1944), wydobytą z dzieł Homera (VIII w.): „Za sprawcę wszystkich wstrząsów ziemi uważano w Grecji Posejdona, którego już Homer mianuje «ziemiodzierżcą» i «wstrząsaczem lądów»: [...]”- T. Zieliński, Grecja niepodległa, Warszawa 1958, 178.

${ }^{10}$ Greckie schematy ekumeny zostały przeanalizowane na bazie źródeł (w ujęciu diachronicznym) w: Kochanek, Schematy ekumeny w literaturze patrystycznej, s. 313-326.

${ }^{11}$ Tamże, s. 315 i przyp. 33. Por. Parmenides, F 18 A 1, w: Die Fragmente der Vorsokratiker, hrsg. von H. Diels und W. Kranz, 6. Aufl., Berlin 1951, Bd. I, 138, 10-11; tenże, F 18 A 44, w: Die Fragmente der Vorsokratiker, Bd. I, s. 145, 16-18.

${ }^{12}$ Jeśli chodzi o zestawienie źródeł odnoszących się do globusa Kratesa oraz do jego idei „pasów oceanicznych" por. P. Kochanek, Die Vorstellung vom Norden und der Eurozentrismus. Eine Auswertung der patristischen und mittelalterlichen Literatur, Veröffentlichungen des Instituts für 
globusa (rys. 1) w nowożytnej nauce dokonał w roku 1892 Konrad Kretschmer (28 VII 1864 - 11 XI 1945) ${ }^{13}$. Badacz ten zilustrował także redukcjonistyczną koncepcję geograficzną Strabona, który uważał, że należy się ograniczyć do dociekań nad tzw. naszą ekumena, jasno zdefiniowaną na globusie Kratesa, a nie odwoływać się do spekulacji nad jego schematem Ziemi jako takiej, i z tą myślą Strabon propagował tzw. parallelogram, czyli równoległobok, jako schemat ekumeny (rys. 2).

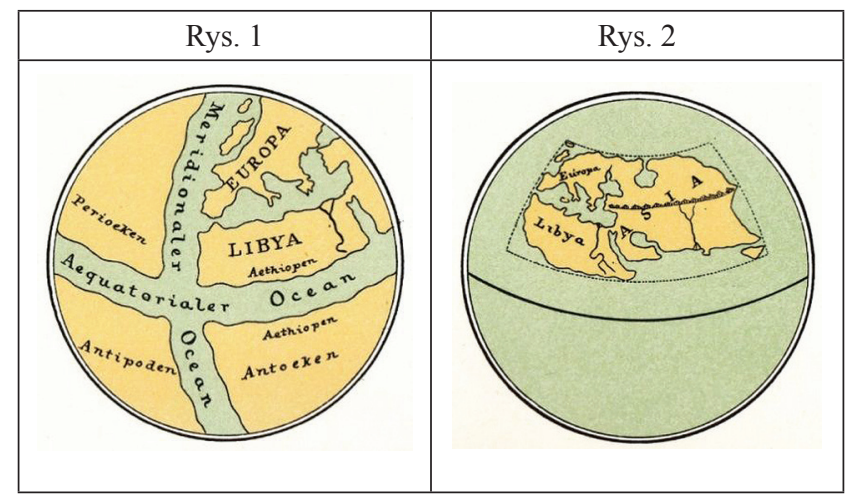

Rys. 1: Globus Krates z Mallos ${ }^{14}$; rys. 2: Ekumena Strabona K. Kretschmera ${ }^{15}$.

Koncepcja Kratesa z Mallos była dobrze znana średniowiecznym uczonym m.in. dlatego, że o ,pasach oceanicznych" wspominali poczytni w tym okresie

Europäische Geschichte Mainz. Abteilung für Abendländische Religionsgeschichte 205, Mainz 2004, 390-393; tenże, Rekonstrukcje globusa Kratesa z Mallos w dwóch polskich podręcznikach historii geografii, „Acta Mediaevalia” 20 (2007) 139-142; tenże, Wspótczesne rekonstrukcje globusa Kratesa z Mallos, w: Archiva temporum testes. Źródta historyczne jako podstawa pracy badacza dziejów, Księga pamiątkowa ofiarowana Profesorowi Stanisławowi Olczakowi, red. G. Bujak - T. Nowicki - P. Siwicki, TN KUL Prace Wydziału Historyczno-Filologicznego 143, Lublin 2008, 247-250; tenże, Schematy ekumeny w literaturze patrystycznej, s. 315, przyp. 35-36; tenże, , Rozestanie Apostołów" na mapie Beatusa z Burgo de Osma, w: Fructus Spiritus est Caritas, Ksiega Jubileuszowa ofiarowana Księdzu Profesorowi Franciszkowi Draczkowskiemu z okazji siedemdziesiatej rocznicy urodzin, czterdziestolecia święceń kapłańskich i trzydziestopięciolecia pracy naukowej, red. M. Wysocki, Lublin 2011, 711-713.

${ }^{13} \mathrm{Na}$ temat współczesnych rekonstrukcji globusa Kratesa z Mallos (wraz z materiałem ilustracyjnych) por. Kochanek, Współczesne rekonstrukcje globusa Kratesa z Mallos, s. 250-260. Por. też tenże, Rekonstrukcje globusa Kratesa z Mallos w dwóch polskich podręcznikach historii geografi, s. 142-151.

${ }^{14} \mathrm{~K}$. Kretschmer, Die Entdeckung Amerika's in ihrer Bedeutung für die Geschichte des Weltbildes. Atlas der Festschrift des Gesellschaft für Erdkunde zu Berlin zur vierhundertjährigen Feier der Entdeckung Amerika's, Berlin-Leipzig 1892 tab. I, rys. 5 (= Die Historischen Karten zur Entdeckung Amerikas. Atlas nach Konrad Kretschmer, Überarbeitete Reprint-Ausgabe des Originals von 1892 hrsg. vom Institut für Iberoamerika-Kunde, Hamburg, in Zusammenarbeit mit der Gesellschaft für Erdkunde zu Berlin, Frankfurt am Main 1991 tab. I, rys. 5).

${ }^{15}$ Kretschmer, Die Entdeckung Amerika's, tab. I, rys. 1 (= Die Historischen Karten zur Entdekkung Amerikas, tab. I, rys. 1). 
autorzy: Cicero, Makrobiusz (1 poł. V w.) i Marcjanus Kapella (2 poł. V w. $)^{16}$. Szczególnie dobrze znani byli dwaj ostatni, o czym świadczy liczba zachowanych kopii ich traktatów: 244 kopie traktatu Marcjanusa Kapelli, które jednak nie zostały opatrzone mapami, i około stu odpisów dzieła Makrobiusza, które zawierają tzw. mapy strefowe ${ }^{17}$. Namacalnym dowodem na znajomość idei Kratesa w średniowieczu jest również wywód Wilhelma z Conches (ok. 1080 - ok. 1154) z początków XII w. na temat czterech ekumen ${ }^{18}$. Schemat kuli ziemskiej przeciętej ,pasami oceanicznymi” i zorientowany w kierunku północnym mógł być wówczas ważny również dlatego, że pasy te tworzą krzyż równoramienny, zwany też krzyżem greckim (rys. 6). Tymczasem odkrywanie różnych naturalnych schematów krzyża w świecie stworzonym było niemal od zarania chrześcijaństwa dowodem, potwierdzającym niejako autentyczność Boskiego dzieła stworzenia i uchodzącym za rodzaj „Bożej pieczęci” odciśniętej na tym dziele ${ }^{19}$. Walory mnemotechniczne schematu opartego z jednej strony na podstawowym symbolu wiary chrześcijańskiej, z drugiej zaś na jednoznacznej geometryzacji przestrzeni są oczywiste. W ten sposób ów, chciałoby się powiedzieć, globalny makro-schemat łączący krzyż i ideą kulistości Ziemi wszedł do naukowego krwioobiegu średniowiecza. Jego mutacją były „mapy strefowe” Makrobiusza ${ }^{20}$. Warto też zauważyć, że krzyż równoramienny wpisuje się niemal naturalnie w geometryczne figury „doskonałe”,

${ }^{16}$ Dokładne dane źródłowe znajdują się w publikacjach podanych (wraz z odpowiednimi stronami) w przyp. 12.

${ }^{17}$ A.-D. von den Brincken, Der vierte Erdteil in der Kartographie des Hochmittelalters, w: Reisen in reale und mythische Ferne. Reisenliteratur in Mittelalter und Renaissance, hrsg. von P. Wunderli, Studia Humaniora 22, Düsseldorf 1993, 17-18 = taż, Studien zur Universalkartographie des Mittelalters, hrsg. von Th. Szabó, Veröffentlichungen des Max-Planck-Instituts für Geschichte 229, Göttingen 2008, 433. Por. M. Destombes, Mappemondes A.D. 1200-1500. Catalogue préparé par la Commission des Cartes Anciennes de l'Union Géographique Internationale, Monumenta Cartographica Vetustioris Aevi I, Amsterdam 1964, $43-45$ (Sections 18-21) - Macrobius; 85-95 (Sections 36-38) - Macrobius [po raz drugi]; 96-109 (Sections 39-42) - Guillaume de Conches. Por. też Kochanek, Die Vorstellung vom Norden und der Eurozentrismus, s. 391; tenże, Rekonstrukcje globusa Kratesa z Mallos, s. 141; tenże, Współczesne rekonstrukcje globusa Kratesa z Mallos, s. 249.

${ }_{18}$ Willelmus de Conches, De philosophia mundi IV 3, PL 172, 85C-86D (= PL 90, 1167C1168D). Por. Kochanek, Die Vorstellung vom Norden und der Eurozentrismus, s. 391; tenże, Rekonstrukcje globusa Kratesa z Mallos, s. 141; tenże, Wspótczesne rekonstrukcje globusa Kratesa z Mallos, s. 249.

${ }^{19}$ Jeśli chodzi o zestaw źródeł patrystycznych i średniowiecznych oraz o bibliografię przedmiotu por. Kochanek, Die Vorstellung vom Norden und der Eurozentrismus, s. 215-216, przyp. 193; tenże, Schematy ekumeny w literaturze patrystycznej, s. 328-329, przyp. 81. Por. też D. Forstner, Świat symboliki chrześcijańskiej. Leksykon, tłum. W. Zakrzewska - P. Pachciarek - R. Turzyński, Warszawa 2001, 15; S. Kobielus, Krzyż Chrystusa. Od znaku i figury do symbolu i metafory, Tyniec 2011 2 , 113-156.

${ }^{20}$ Por. Kochanek, Schematy ekumeny w literaturze patrystycznej, s. 328-329; tenże, Cesarstwo Bizantyńskie w kartografii Zachodu około roku 1000, „Teka Komisji Historycznej PAN” 12 (2015) 26-33. 
czyli w okrąg i w kwadrat ${ }^{21}$. W kontekście „mapy strefowej” Makrobiusza i jej mutacji należy zwrócić uwagę na zastosowaną w nich prostą i sugestywną geometryzację przestrzeni, która tworzy klarowny i użyteczny schemat mnemotechniczny (rys. 3-5).

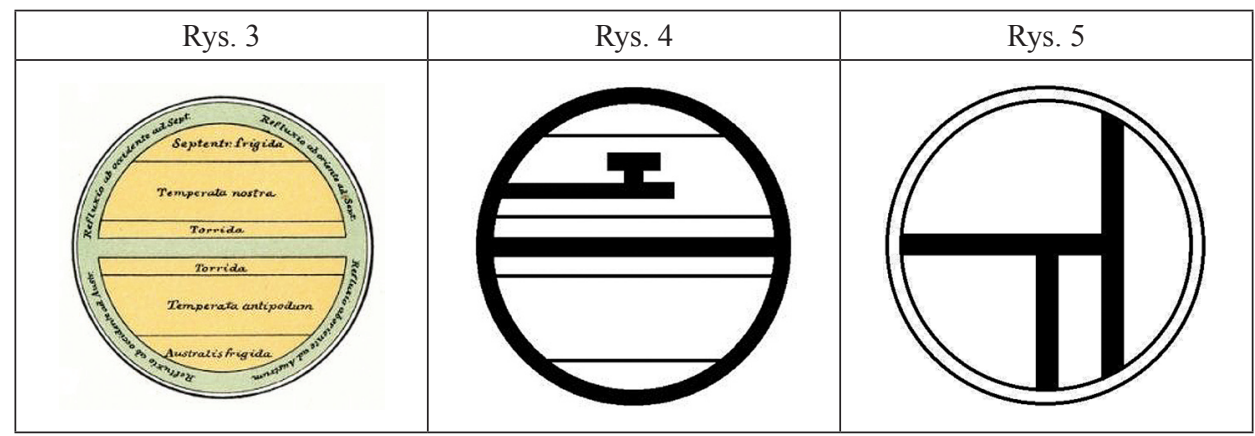

Rys. 3: Schemat „mapy strefowej” Makrobiusza ${ }^{22}$; rys. 4: Uszczegółowiony schemat mapy Makrobiusza; rys. 5: Schemat map Beatusa z Liébana ${ }^{23}$.

Obok owego globalnego schematu funkcjonował również w średniowieczu, jak wiadomo, schemat „ekumeniczny”, czyli tzw. mapy O-T. Z mnemotechnicznego punktu widzenie ciekawie wypada zestawienie logiki schematu Kratesowych ,pasów oceanicznych” ze schematem O-T. Oto bowiem schemat O-T po raz kolejny opowiedział się po stronie geometryzacji przestrzeni, eksponowając przy tym znak Krzyża, który tym razem przybrał formę Tau (rys. 7) ${ }^{24}$ i został wpisany w ekumenę. Ta forma krzyża „ekumenicznego” zawdzięcza swą pozycję w kartografii chrześcijańskiej autorytetowi Augustyna (13 XI 354 - 28 VIII 430), który definiując wzajemne proporcje między Afryką, Azją i Europą w ramach naszej ekumeny stwierdził, że obszar Azji jest równy terytorium dwóch pozostałych kontynentów ${ }^{25}$. Ponieważ zaś schemat ten był zorientowany na wschód, zatem trójpodział ów narzucał wręcz geometryzację obszaru ekumeny w formie Tau. W ten sposób po raz kolejny ujawnił się zakodowany w stworzeniu znak jego Stwórcy. Wprowadzając krzyż jako podstawowy element schematu ekumeny, chrześcijaństwo niejako w sposób naturalny weszło w antyczną geo- i kartografię, czy wręcz ją „,schrystianizowało” nie ingerując przy tym w żadne ważne dla jej istoty zagadnienie. Spojrzenie chrześcijańskie odsłaniało natomiast (na własny niejako użytek) swego rodza-

${ }^{21}$ Por. Kochanek, Schematy ekumeny w literaturze patrystycznej, s. 330.

${ }^{22}$ Schemat ten pochodzi z: Kretschmer, Die Entdeckung Amerika's, tab. I, rys. 4 (= Die Historischen Karten zur Entdeckung Amerikas, tab. I, rys. 4).

${ }^{23}$ Schemat ten to de facto podwójny krzyż Tau, który można uznać za chrześcijańską „,reinterpretację” tzw. „map strefowych” Makrobiusza.

${ }^{24}$ Por. Forstner, Świat symboliki chrześcijańskiej, s. 13-14 i 30-31; Kobielus, Krzyż Chrystusa, s. 176.

${ }^{25}$ Augustinus, De civitate Dei XVI 17, ed. E. Hoffmann: Augustinus, De civitate Dei, CSEL 40/2, Wien 1900, 159, 7-12 (= CCL 48, 521, 12-17 = PL 41, 497). 
ju drugie dno tej dziedziny wiedzy. Schemat Augustyna przejęli inni uznani pisarze kościelni chrześcijańskiego Zachodu i to ich autorytet zadecydował o jego rozpropagowaniu ${ }^{26}$.

Przypadek „krzyża globalnego" 27 i „krzyża ekumenicznego” odczytane w kontekście niniejszych analiz pokazują dobrze związek pomiędzy schematyzacja, geometryzacją i mnemotechniką. Z drugiej zaś strony ponad tym zestawieniem stoi prosty i głęboko chrześcijański podtekst, który sugeruje jednoznacznie, że Krzyż jest jedynym punktem odniesienia, wykraczającym poza reguły schematyzacji, geometryzacji i mnemotechniki. On jest po prostu wpisany zarówno w naturę świata, jak i w ludzką myśl. Nie ma źródeł, które pozwoliłyby na zweryfikowanie lub sfalsyfikowanie tej tezy, jednak wiadomo, że tzw. Ojcowie Kościoła mieli głównie na uwadze kwestie wiary a nie „nauk świeckich", stąd wyeksponowanie Krzyża, czyli swoisty staurocentryzm, suponujący chrystocentryzm, zdaje się wskazywać na jednoznaczne intencje Augustyna i jego w tym względzie kontynuatorów ${ }^{28}$.

\begin{tabular}{|l|l|}
\hline Rys. 6 & Rys. 7 \\
\hline
\end{tabular}

Rys. 6: Krzyż równoramienny (Ziemia podzielona pasami oceanicznymi Kratesa); rys. 7: Krzyż Tau (Ekumena podzielona na trzy kontynenty) ${ }^{29}$.

Powyższą tezę wzmacnia jeszcze inny przykład geometrycznej schematyzacji ekumeny. Schematem tym jest tzw. akrostych imienia Adam. Geneza i źródła, w których schemat ten się pojawia, były już przedmiotem dociekań niżej podpisanego ${ }^{30}$, zatem tutaj należy przejść od razu do istoty rzeczy. Akro-

${ }^{26}$ Wykaz tych źródeł oraz opracowań na ten temat: Kochanek, Die Vorstellung vom Norden und der Eurozentrismus, s. 170, przyp. 23 i 24; tenże, Schematy ekumeny w literaturze patrystycznej, s. 336, przyp. 100.

${ }^{27}$ Por. Kochanek, Schematy ekumeny w literaturze patrystycznej, s. 329. Tam zostały użyte terminy: „krzyż wszechziemski” i „krzyż ekumeniczny”.

${ }^{28}$ Por. Kochanek, Schematy ekumeny w literaturze patrystycznej, s. 338.

${ }^{29}$ Rysunki nr 4-7 zostały wykonane przez autora niniejszego artykułu.

${ }^{30}$ Por. Kochanek, Die Vorstellung vom Norden und der Eurozentrismus, s. 164-218; tenże, Anatole-Dysis-Arktos-Mesembria, VoxP 28 (2008) t. 52/1, 471-488; tenże, Boska prawica a europocentryzm, w: Wiedza między słowem a obrazem, redakcja: M. Zemła - A. Jabłoński - J. Szymczyk, Studia nad Wiedzą 3, Lublin 2010, 160-164 i 170-171; tenże, Schematy ekumeny w literaturze patrystycznej, s. 321-328. Por. też tenże, Etnomedycyna hippokratejska a geopolityczna myśl grecka w V w. p.n.e., w: Kontrowersje dyskursywne. Między wiedzq specjalistycznq a praktyka społecz$n q$, redakcja: A. Jabłoński - J. Szymczyk - M. Zemła, Studia nad Wiedzą 4, Lublin 2012, 27-56 
stych powstał na bazie greckich nazwy czterech stron świata. Pierwsze lite-

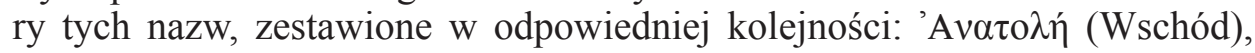

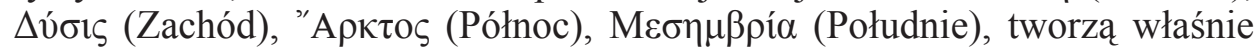
akrostych imienia Adam (rys. 8). Explicite schemat ten widnieje na dwóch mapach średniowiecznych: na tzw. mapie Oksfordzkiej (rys. $\left.9=\mathrm{A}^{1 / 14}\right)^{31}$ i na mapie z Kompendium Wiedeńskiego (rys. $\left.12=\mathrm{A}^{1 / 65}\right)^{32}$. Mapy te posiadają bowiem wśród wpisanych w nie legend greckie nazwy kierunków kardynalnych. Natomiast implicite, a dokładnie w formie graficznej (obraz ekumeny wpisanej w ciało Chrystusa), schemat ten przedstawiono na mapie z Ebstorf (rys. $\left.10=\mathrm{A}^{1 / 54}\right)^{33}$ i na mapie $\mathrm{z}$ Lambeth Palace Library (rys. $\left.11=\mathrm{A}^{1 / 56}\right)^{34}$.

(szczeg. s. 30-40); tenże, Kartografia antropomorficzna a europejska ideologia hierarchii narodów, w: Kreowanie społeczeństwa niewiedzy, redakcja: A. Jabłoński - J. Szymczyk - M. Zemła, Studia nad Wiedzą 7, Lublin 2015, 101-159, spec. s. 102-108.

${ }^{31}$ Źródło oryginału: Oksford, St. John's College, Ms 17, fol. $6^{\mathrm{r}}$ (średnica oryginału: $170 \mathrm{~mm}$; data powstania: 1110). Por. M. Destombes, Mappemondes A.D. 1200-1500, s. 48 (25,8); A.-D. von den Brincken, Fines Terrae. Die Enden der Erde und der vierte Kontinent auf mittelalterlichen Weltkarten, Monumenta Germaniae Historica. Schriften 36, Hannover 1992, XIX (29) i 66-67; L.S. Chekin, Northern Eurasia in Medieval Cartography. Inventory, Text, Translation, and Commentary, Terrarum Orbis 4, Turnhout 2006, 64-65 (III.2.2.). • Tekst legend mapy: K. Miller, Mappaemundi. Die ältesten Weltkarten, III. Heft: Die kleineren Weltkarten, Stuttgart 1895, 118-119; A.-D. von den Brincken, Gyrus und Spera - Relikte griechischer Geographie im Weltbild der Frühscholastik (Aufgezeigt an fünf lateinischen Weltkarten des beginnenden 12. Jahrhunderts), „Sudhoffs Archiv" 73 (1989) Heft 2, 141-144 (= taż, Studien zur Universalkartographie des Mittelalters, s. 361-365); Chekin, Northern Eurasia in Medieval Cartography, s. 65-66 (III.2.2.).

${ }^{32}$ Źródło oryginału: Wiedeń, Österreichische Nationalbibliothek, Cod. Vind. 505, fol. $1^{\mathrm{r}}$ (średnica oryginału: $160 \mathrm{~mm}$; data powstania: XIV w.). Por. M. Destombes, Mappemondes A.D. 12001500, s. 178 (50,21); Brincken, Fines Terrae, s. XXIV (69) i s. 135-136. • Tekst legend mapy: Destombes, Mappemondes A.D. 1200-1500, s. 178-179 (50,21).

${ }_{33}$ Źródło oryginału: Mapa spłonęła w czasie bombardowania Hauptstaatsarchiv w Hanowerze w nocy z 8 na 9 października 1943 (wielkość oryginału: 3580 × $3560 \mathrm{~mm}$; data powstania: ok. 1300). Por. Destombes, Mappemondes A.D. 1200-1500, s. 194-197 (52,2); Brincken, Fines Terrae, s. XXIII (59) i s. 91-93; J. Wilke, Die Ebstorfer Weltkarte, I: Textband, Veröffentlichungen des Instituts für Historische Landesforschung der Universität Göttingen 39, Bielefeld 2001, 11-12 i przyp. 14; B. Englisch, Ordo orbis terrae. Die Weltsicht in den Mappae mundi der frühen und hohen Mittelalters, Orbis Mediaevalis 3, Berlin 2002, 468-472 i 653; Chekin, Northern Eurasia in Medieval Cartography, s. 146-151 (X.11.). • Tekst legend mapy: E. Sommerbrodt, Die Ebstorfer Weltkarte, [Teil: Text], Hannover 1891; K. Miller, Mappaemundi. Die ältesten Weltkarten, V. Heft: Die Ebstorfkarte, Stuttgart 1896; Die Ebstorfer Weltkarte. Kommentierte Neuausgabe in zwei Bänden. Bd. I: Atlas; Bd. II: Untersuchungen und Kommentar, hrsg. von H. Kugler, unter Mitarbeit von S. Glauch - A. Willing, Berlin 2007. • Fragmenty tekstu legend mapy: I. Hallberg, L'Extrème Orient dans la littérature et la cartographie de l'Occident des XIII ${ }^{e}, X I V^{e}$ et XVe siècles. Études sur l'histoire de la géographie, Göteborg 1906 (nazwy geograficzne w porządku alfabetycznym); Средневековье въ его памятникахъ: сборникъ переводовъ, подъ редакціей Д.Н. Егорова, Москва 1913, 276-289 (rosyjski przekład wybranych legend, bazujący na powyższym wydaniu K. Millera); Chekin, Northern Eurasia in Medieval Cartography, s. 151-161 (X.11.).

${ }^{34}$ Źródło oryginału: Londyn, Lambeth Palace Library, Ms 371, fol. $9^{v}$ (średnica oryginału: $66 \mathrm{~mm}$; data powstania: ok. 1300). Por. Chekin, Northern Eurasia in Medieval Cartogra- 
W kartografii średniowiecznej akrostych ten, jak wiadomo, nie jest li tylko grą słów, lecz odnosi się do typologii Adam-Chrystus, której podstawowa teza biblijna brzmi: ,Jak w Adamie wszyscy umierają, tak w Chrystusie wszyscy będą ożywieni" (1Kor 15, 22; por. Rz 5, 12-21) ${ }^{35}$. Chrystus zatem to Nowy Adam, który dokonał dzieła odrodzenia pochodzącej od praojca Adama i upadłej skutkiem tzw. grzechu pierworodnego ludzkość.

Te cztery zachowane mapy de facto łączą akrostych imienia Adam z ideą równoramiennego krzyża, co pogłębia ich teologiczne przesłanie. Zapamiętanie choćby tych podstawowych schematów wprowadzało zatem widza-czytelnika mapy w tzw. historię zbawienia w jej geograficznym i teologicznym aspekcie. Taka struktura mapy była niewątpliwie czymś więcej niż graficzną „Biblią dla maluczkich” (którą w tym sensie można określić mianem „Biblia pauperum"). Była raczej użyteczną pomocą dydaktyczną, stanowiącą pretekst do głębszej refleksji teologicznej, której poziom zależał w gruncie rzeczy od inwencji i erudycji wykładowcy, czy też komentatora danej mapy oraz od stopnia przygotowania słuchaczy.

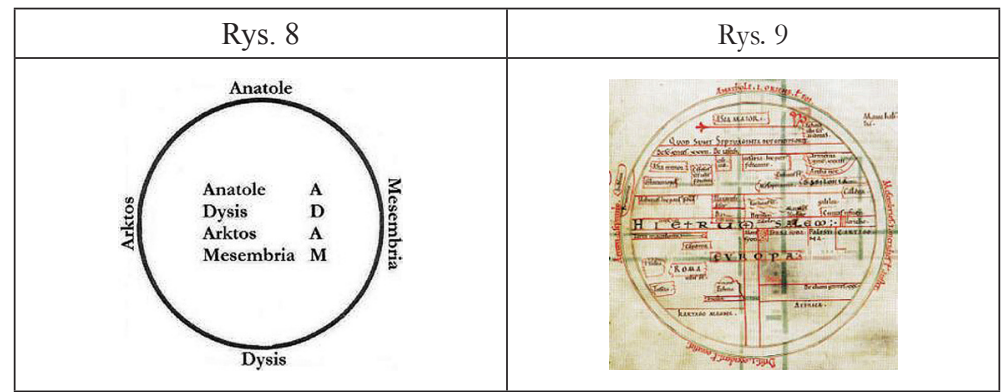

Rys. 8: Kartograficzny akrostych „ADAM”36; rys. 9: Mapa Oksfordzka ${ }^{37}$

phy, s. 72 (III.2.8.). • Tekst legend mapy: Chekin, Northern Eurasia in Medieval Cartography, s. $72-73$ (III.2.8.).

${ }^{35}$ Cytat za przekładem Biblii Tysiaclecia, wyd. 2, Poznań - Warszawa 1971.

${ }^{36}$ Schemat kartograficznego akrostychu imienia Adam, którego autorem jest niżej podpisany, był już kilka razy reprodukowany: Kochanek, Anatole - Dysis - Arktos - Mesembria, s. 471; tenże, Boska prawica a europocentryzm, s. 165, rys. 1B; tamże, s. 171, rys. 4; tenże, Schematy ekumeny w literaturze patrystycznej, s. 330, rys. 3A.

${ }^{37}$ Źródło kopii: E. Edson - E. Savage-Smith, Medieval Views of the Cosmos. Picturing the Universe in the Christian and Islamic Middle Ages, with a forword by T. Jones, Oxford 2004, 68, rys. 34. Por. (inne kolorowe reprodukcje tejże mapy): E. Edson - E. Savage-Smith - A.-D. von den Brincken, Der mittelalterliche Kosmos. Karten der christlichen und islamischen Welt, Aus dem Englischen von T. Ganschow, 2. Aufl., Darmstadt 2011, 56, rys. 39; Chekin, Northern Eurasia in Medieval Cartography, s. 365 (III.2.2.); R. Galichian, Countries south of the Caucasus in Medieval Maps. Armenia, Georgia and Azerbaijan, London 2007, 61, rys. 25; F. Reichert, Das Bild der Welt im Mittelalter, Darmstadt 2013, 33, rys. 3. 


\begin{tabular}{|c|c|c|}
\hline Rys. 10 & Rys. 11 \\
\hline \\
\hline
\end{tabular}

Rys. 10: Schemat akrostychu na mapie z Ebstorf ${ }^{38}$; rys. 11: Mapa z Lambeth Palace Library (ok. 1300) ${ }^{39}$; rys. 12: Mapa z Kompendium Wiedeńskiego (XIV w.) ${ }^{40}$.

Obok powyższych map istnieje jeszcze wiele średniowiecznych przykładów graficznego odwoływania się do akrostychu imienia Adam. Robiono to najczęściej bez użycia nazw greckich czterech stron świata. Jednak niniejsze rozważania ograniczają się wyłącznie do map, a zatem nie ma tutaj miejsca na rozszerzenie zakresu analizowanego materiału źródłowego ${ }^{41}$. Mnemotechnika

${ }^{38}$ Również schemat akrostychu na mapie z Ebstorf jest autorstwa niżej podpisanego. Por. B. Wolf, Jerusalem und Rom: Mitte, Nabel - Zentrum, Haupt. Die Metaphern „Umbilicus mundi” und "Caput mundi" in den Weltbildern der Antike und des Abendlands bis in die Zeit der Ebstorfer Weltkarte, Bern 2010, 31, rys. 5.

39 Źródło kopii: Chekin, Northern Eurasia in Medieval Cartography, s. 371 (III.2.8.). Por. M. Kupfer, Reflections in the Ebstorf Map. Cartography, Theology and dilectio speculationis, w: Mapping Medieval Geographies. Geographical Encounters in the Latin West and Beyond, 3001600, ed. by K.D. Lilley, Cambridge 2013, 107, rys. 5.2. Por. też S.D. Westrem, Geography and Travel, w: A Companion to Chaucer, ed. by P. Brown, Blackwell Companions to Literature and Culture [6], Oxford 2000, rys. 12.1; A. Scafi, Mapping Paradise. A History of Heaven on Earth, Chicago 2006, 131; Ch. Van Duzer - S. Sáenz-López Pérez, Tres filii Noe diviserunt orbem post diluvium: The World Map in British Library Add. Ms. 37049, „Word and Image” 26 (2010) nr 1, 30; T. Lester, Da Vinci's Ghost: Genius, Obsession, and How Leonardo Created the World of His Own Image, New York 2012, XVII, rys. 1; B. Schöller, Transfer of Knowledge: Mappa Mundi Between Texts and Images, „Peregrinations” 4 (2013) nr 1, 44, rys. 1 oraz 50, rys. 4.

40 Źródło kopii: Destombes, Mappemondes A.D. 1200-1500, tablica XVb (P). Por. tamże, s. 178 (50,21): „Les noms des points cardinaux sont adapté du grec: Dysis, Menserum, Anathole (à l'Ouest!) et Arthos (à l'Est!)”. Por. A. Külzer, Die Weltkarte des ,, Wiener Kompendium”. Der Codex Vindobonensis 505 saec. XIV und seine Karte des byzantinischen Reiches, „Biblos” 45 (1996), 227 (reprodukcja mapy) i 230: „Die Beschreibung der Karte ist, [...], von einiger Originalität: die Himmelsrichtungen sind nämlich mit den lateinischen Buchstaben gehaltenen griechischen Termini angegeben, doch unterlief dem Zeichner dabei eine Verwechslung, er stellte nämlich Dysis in den Osten, Anathole in den Westen, bezeichnete den Osten als Arthos (= Arctos), den Süden als Menseuion (= Mensebrion)".

${ }^{41}$ Por. H. Liebeschütz, Das allegorische Weltbild der heiligen Hildegard von Bingen, Studien der Bibliothek Warburg 16, Leipzig - Berlin 1930 [reprint: Darmstadt 1964], 86-107; B. Bronder, Das Bild der Schöpfung und Neuschöpfung der Welt als orbis quadratus, „Frühmittelalterliche Studien” 6 (1972) 188-210; A. Wolf, Ikonologie der Ebstorfer Weltkarte und politische Situation des Jahres 1239. Zum Weltbild des Gervasius von Tilbury am welfischen Hofe, w: Ein Weltbild vor Columbus. Die Ebstorfer Weltkarte. Interdisziplinäres Colloquium 1988, hrsg. von H. Kugler - E. Michael, Acta Humaniora, Weinheim 1991, 101, rys. 2; B. Hahn-Woernle, Die Ebstorfer Weltkarte und 
oparta o geometryczną schematyzację przestrzeni występuje jednak na mapach średniowiecznych nie tylko w makroskali, czyli, etymologicznie rzecz ujmując, w skali geograficznej i geometrycznej.

Drugim polem zastosowania mnemotechniki jest „choroskala”. Ten pozorny neologizm opiera się na dwóch pojęciach, znanych z antycznych źródeł greckich. Są nimi terminy $\chi \omega \rho о \gamma \rho \alpha \varphi^{\prime} \alpha^{42}$ i $\chi \omega \rho о \mu \varepsilon \tau \rho i ́ \alpha^{43}$, czyli odpowiednio opis i pomiar danego regionu ekumeny. W przypadku chorografii i chorometrii można na zasadzie analogii odwołać się do przedstawionej wyżej tezy Strabona i stwierdzić, że istnieją czynniki takie jak morze, rzeki, czy też góry, które opisują ( $\chi \omega \rho о \gamma \rho \alpha \varphi \varepsilon ́ \omega)$ i nadają kształt $(\sigma \chi \eta \mu \alpha \tau i \zeta \omega)$ danemu regionowi ekumeny. Podobnie jak w przypadku geografii i geometrii, bliski związek między chorografią, chorometrią, schematyzacją i mnemotechniką jest oczywisty. Mnemotechnika, bazując na zapamiętanym, charakterystycznym schemacie fragmentu mapy, pozwala łatwo odnaleźć poszczególne obszary lub konkretne miejsca ekumeny ${ }^{44}$.

Trzecim wreszcie aspektem zastosowania mnemotechniki w kartografii

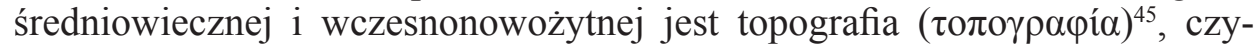
li opis danego miejsca. Warto przy tym zauważyć, że zachowane antyczne źródła greckie nie znają terminu topometria ( powyższej tezy Strabona można by powiedzieć, że istnieją pewne podstawy,

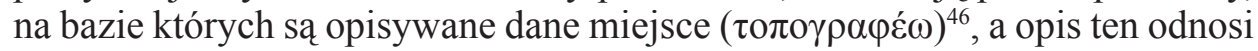
się także do ich kształtu $(\sigma \chi \eta \mu \alpha \tau i ́ \zeta \omega)$. W przypadku analizowanych tutaj map podstawą tą na poziomie topografii była zwykle ludzka wyobraźnia, której silnego wsparcia udzielała przekazywana z pokolenia na pokolenie tradycja.

Fortuna Rotis-Vorstellungen, w: Ein Weltbild vor Columbus, s. 185-201; K. Clausberg, Scheibe, Rad, Zifferblatt. Grenzübergänge zwischen Weltkarten und Weltbildern, w: Ein Weltbild vor Columbus, s. 279, rys. 10; s. 303-310; Kochanek, Die Vorstellung vom Norden und der Eurozentrismus, s. 205-208; Wolf, Jerusalem und Rom: Mitte, Nabel-Zentrum, Haupt, s. 340, rys. 9.4; s. 357, rys. 9.21 ; s. 359 , rys. 9.23 ; s. 362 , rys. 9.25 ; s. 363 , rys. 9.27 ; s. 369 , rys. 9.33 .

42 Por. Polybius, Historiae XXXIV 1, 5, ed. Th. Büttner-Wobst: Polybius, Historiae, vol. 4 , Lipsiae 1904, 402, 11; Strabo, Geographica VIII 3, 17, C. 346, ed. Meineke, vol. 2, s. 492, 20; Ptolemaeus Claudius, Geographia Prologus $\alpha$, ed. C.F.A. Nobbe: Ptolemaeus Claudius, Geographia, t. 1, Lipsiae 1843 [reprint: Hildesheim 1990], 1; tamże, I 1, 1-9, ed. Nobbe, t. 1, s. 3, 1 - 5, 13.

${ }^{43}$ Por. Strabo, Geographica XVI 2, 24, C. 757, ed. Meineke, vol. 3, s. 1056, 20-21.

${ }^{44}$ Bardzo duży zbiór schematów chorograficznych i topograficznych występujących w źródłach antycznych zebrał o przeanalizował niżej podpisany w artykule: Iluzja schematów choro- $i$ topograficznych, s. 75-126. W literaturze polskiej funkcjonują również dwa krótkie zestawienia antycznych schematów choro- i topograficznych: B. Gustawicz, Zarys historyczny sposobów kreślenia kart geograficznych, w: Sprawozdanie dyrektora C. K. gimnazyum nowodworskiego św. Anny w Krakowie za rok szkolny 1882, Kraków 1882, 5 i 7 [Odbitka: Kraków 1882, s. 5 i 7]; J. Staszewski, Środowisko geograficzne w nauce antycznej, s. 37.

${ }^{45}$ Por. Strabo, Geographica VIII 1, 3, C. 334, ed. Meineke, vol. 2, s. 475, 19; Ptolemaeus Claudius, Geographia I 1, 6, ed. Nobbe, t. 1, s. 4, 21.

${ }^{46}$ Por. Strabo, Geographica XIII 1, 5, C. 583, ed. Meineke, vol. 3, s. 817, 23. 
Źródłem zaś inspiracji dla wyobraźni było najczęściej ukształtowanie danego terenu lub też, jako element wtórny, zastane nazewnictwo.

W poniższych analizach choro- i topograficznych zostaną wykorzystane trzy narzędzia pomocnicze. Pierwszym i podstawowym jest artykuł niżej podpisanego, opublikowany w roku 2012, który analizuje zebrane w źródłach antycznych i średniowiecznych schematy choro- $i$ topograficzne ${ }^{47}$. Drugie narzędzie to „Aneks I”, będący chronologicznym zastawieniem „metryk” map średniowiecznych i wczesnonowożytnych, wykorzystanych jako źródła graficzne w niniejszym artykule. Trzecim intrumentem, którego znaczenie należy jednak uznać za marginalne, jest tablica („Aneks II”) wizualizująca najbardziej znane geo- i chorograficzne schematy starożytne. Wspomniany wyżej artykuł będzie wykorzystywany systematycznie w przypisach, natomiast dwa pozostałe elementy, szczególnie „Aneks I”, mają stanowić dla czytelnika instruktywne punkty odniesienia. Numery poszczególnych map zawartych w rzeczonym aneksie nr I będą towarzyszyć ich przywołaniom w tekście artykułu (w postaci odpowiednich cyfr umieszczonych zwykle w nawiasach kwadratowych od „A $\mathrm{A}^{1 / 1}$ ” do , $\mathrm{A}^{1 / 75}$ ”).

Mnemotechnika chorograficzna antyku zaaplikowana do objętych tytułem niniejszego artykułu map jest najłatwiej uchwytna na przykładzie oceanu otaczającego ekumenę. Starożytni, jak wiadomo, stosowali w odniesieniu do niego schemat okręgu ${ }^{48}$. Ich następcy, przynajmniej od czasów Orozjusza (ok. 380 - ok. 420), określali go dość często mianem limbus, widząc w rzeczonym oceanie swego rodzaju „lamówkę” ekumeny ${ }^{49}$. Najprawdopodobniej konsekwencją takiego postawienia sprawy jest charakterystyczny, regularny pasek oceaniczny, stanowiący obwódkę wielu map średniowiecznych. Ma on zwykle kolor błękitny lub zielony (z wyjątkiem Morza Czerwonego) ${ }^{50}$, a na tym tle

${ }^{47}$ Kochanek, Iluzja schematów choro- i topograficznych, s. 75-122.

${ }^{48} \mathrm{~W}$ kwestii zestawienie źródeł por. Kochanek, Iluzja schematów choro- $i$ topograficznych, s. 76 i przyp. 6.

${ }^{49}$ Orosius, Historia adversus paganos I 2, 1, ed. K. Zangemeister: Orosius, Historia adversus paganos. Liber apologeticus, CSEL 5, Wien 1882 [reprint: Hildesheim 1967], 9, 1 (= PL 31, 672B = Geographi Latini Minores, rec. A. Riese, Heilbronn 1878 [reprint: Hildesheim 1964], 56, 1). Por. Cosmographia I 1a, w: Geographi Latini Minores, s. 71, 4; tamże II 1, w: Geographi Latini Minores, s. 90, 61; Situs orbis terre vel regionum, V 1, ed. P. Gautier Dalché: Situs orbis terre vel regionum: Un traité de géographie inédit du haut Moyen Âge (Paris, B. N. Latin 4841), „Revue d'Histoire des Textes" 12-13 (1982-1983) 164, 17-18; Dudo Decanus, De moribus et actis primorum Northmanniae ducum, PL 141, 619A; Willelmus Calculus, Historiae Northmannorum, PL 149, 871C; Honorius Augustodunensis, Imago mundi I 39, ed. V.I.J. Flint: Honorius Augustodunensis, Imago mundi, „Archives d'Histoire Doctrinale et Littéraire du Moyen Âge” 57 (1982) 68 (= PL 172, 133D); Gervasius Tilleberiensis, Otia imperialia II 13, ed. S.E. Banks - J.W. Binns: Gervase of Tilbury, Otia imperialia, Oxford Medieval Texts, Oxford 2002, 346. Por. też Kochanek, Iluzja schematów choro- i topograficznych, s. 76, przyp. 7.

${ }^{50}$ Por. A.-D. von den Brincken, Die Ausbildung konventioneller Zeichen und Farbgebungen in der Universalkartographie des Mittelalters, „Archiv für Diplomatik. Schriftgeschichte, Siegel- und 
widnieją zwykle wyspy o kształcie podłużnym (owalnym), prostokątnym lub okragłym. Niekiedy w toni oceanu umieszczano ryby lub łodzie. Te pierwsze pojawiają się głównie na tzw. mapach Beatusa z Liébana, a ściślej na: 1. mapie $\mathrm{z}$, The Morgan Beatus” (940-945) [A $\left.{ }^{1 / 3}\right]$, 2. mapie Beatusa $\mathrm{z}$ Valladolid (970) $\left[\mathrm{A}^{1 / 6}\right]$, 3. mapie Beatusa $\mathrm{z}$ Gerony (975) $\left[\mathrm{A}^{1 / 7}\right]$, 4. mapie $\mathrm{z}$,Facundus Beatus” (1047) [A $\left.{ }^{1 / 17}\right]$, 5. mapie Beatusa z Saint-Séver (1047-1072) [A $\left.1 / 18\right]$, 6. mapie Beatusa z Burgo de Osma (1086) [A ${ }^{1 / 20}$ ], 7. mapie Beatusa z Silos (1109) $\left[\mathrm{A}^{1 / 29}\right]$, 8. mapie $\mathrm{z}$,The Ryland Beatus” (ok. 1175) [A $\mathrm{A}^{1 / 40]}$, 9. mapie Beatusa z Lorvão (ok. 1189) [A $\left.\mathrm{A}^{1 / 41}\right]$, 10. mapie Beatusa z Nawarry (koniec XII w.) [A $\left.{ }^{1 / 42}\right]$, 11. mapie Beatusa $z$ Las Huelgas (1220) [ $\mathrm{A}^{1 / 46}$ ] oraz 12. mapie Beatusa $\mathrm{z}$ Arroyo (poł. XIII w.) [A ${ }^{1 / 48}$ ]. Poza tym niektóre mapy Beatusa maja ową lamówkę ozdobioną nie tylko rybami, lecz również, jak już wspomniano, miniaturowymi statkami lub łodziami rybackimi. Do tej grupy należy: 1. mapa Beatusa z Valladolid (970) [A $\mathrm{A}^{1 / 6}$ ], 2. mapa Beatusa z Gerony (975) [A $\left.\mathrm{A}^{1 / 7}\right]$, 3. mapa $\mathrm{z}$,The Ryland Beatus” (ok. 1175) [ $\mathrm{A}^{1 / 40}$ ], 4. mapa Beatusa $\mathrm{z}$ Las Huelgas (1220) [ $\left.\mathrm{A}^{1 / 46}\right]$, 5. mapa Beatusa $\mathrm{z}$ Arroyo (poł. XIII w.) [ $\left.\mathrm{A}^{1 / 48}\right]$. W ten sposób powstała barwna i ,żywa" lamówka mapy zgodnie z przekazem hiszpańskiego autorytetu tej epoki, jakim był Orozjusz, a schemat ten wprowadził do kartografii średniowiecznej zapewne sam Beatus z Liébana (ok. 730 - 798), hiszpański benedyktyn, rysując go na zaginionym dziś oryginale mapy. $\mathrm{W}$ ten sposób ocean stał się interesującym graficznie elementem miniatury, wzbogacającym jej kolorystykę, co wraz z innymi miniaturami podnosiło znacznie cenę ,rynkową” manuskryptu jako takiego.

$\mathrm{Z}$ morzem są także związane dwa inne schematy stosowane na analizowanych tutaj mapach. Odnoszą się one do zespołu akwenów morskich jaki tworzy Morze Czarne, Morze Marmara i Morze Egejskie. Kształt tego pierwszego zestawiano często z kształtem napiętego łuku scytyjskiego ${ }^{51}$. Natomiast co do Morza Marmara, czyli starożytnej Propontydy, to u Ammianus Marcellinus (ok. 330 - ok. 395) zachowała się wzmianka o tym, że jej schematem były grecka litera $\Phi^{52}$. Idąc tym tropem i analizując schematy Morza Czarnego na mapach średniowiecznych można dostrzec przynajmniej w trzech przypadkach echo tej antycznej koncepcji (por. tab. I) ${ }^{53}$. Jednak kształt litery $\Phi$ przeszedł wyraźnie z Morza Marmara na Morze Czarne, natomiast obraz ,łuku scytyjskiego" uległ całkowitemu zatarciu. Sugeruje to, że średniowieczni

Wappenkunde" 16 (1970), tablica między s. 336 a 337 (= taż, Studien zur Universalkartographie des Mittelalters, s. 124).

${ }^{51}$ Por. Kochanek, Iluzja schematów choro- i topograficznych, s. 100 i przyp. 124. W przypisie tym zestawiono w porządku chronologicznym źródła wzmiankujące ten właśnie schemat Morza Czarnego. Por. też Aneks II.

${ }^{52}$ Ammianus Marcellinus, Res gestae XXII 8, 4, rec. V. Gardthausen: Ammianus Marcellinus, Res gestae, vol. 1, Lipsiae 1874, 275, 16. Por. tamże, XXII 8, 6, rec. Gardthausen, vol, 1, s. 276, 1. Por. też Kochanek, Iluzja schematów choro- i topograficznych, s. 97 i przyp. 110.

${ }_{53}$ Por. П. Коханек, Генезис схематического образа побережья Чёрного моря на картах XV века, „Bulgarian Historical Review” 41 (2013) nr 3-4, 17, rys. 9A-C. 
kartografowie podchodzili bardzo elastyczności do dawnych schematów, wykorzystując je raczej jako źródło inspiracji niż jako konkretną wytyczną w sferze schematyzacji danych akwenów wodnych. Poza tym schemat litery $\Phi$ w odniesieniu do Propontydy był użyteczny w kontekście chorograficznym, który obejmował Dardanele (antyczny Hellespont), Propotydę i Bosfor. Należy również zwrócić uwagę na fakt, iż małych rozmiarów mapy średniowieczne nie dostrzegały, rzec by można, tego rodzaju „mikroelementów”, które nie mieściły się w ich skali. W konsekwencji, chcąc posłużyć się danym schematem, rysownik mapy był za każdym razem zmuszony niejako dopasować go do skali tworzonej przez siebie mapy. W ten sposób schemat $\Phi$ objął ów zespół akwenów wodnych, natomiast schemat „łuku scytyjskiego” został skazany przez kartografów na zapomnienie. Można również w zastosowaniu tego schematu dopatrywać się świadomej archaizacji danej mapy, celem nadania jej swego rodzaju „czcigodności”, bazującej na szacownej tradycji antycznej. Warto zauważyć, że wśród map, na których widnieje rzeczony schemat, jest ponownie jedna $\mathrm{z}$ tzw. map Beatus $\mathrm{z}$ Liébana, a dokładnie mapa Beatusa z Saint-Séver (1047-1072) [A¹/18], co także może świadczyć o pewnej ciagłości tradycji kartograficznej na terenie średniowiecznej Hiszpanii.

Tab. I: Schemat Morza Marmara, Morza Czarnego i Morza Egejskiego w formie litery $\Phi$.

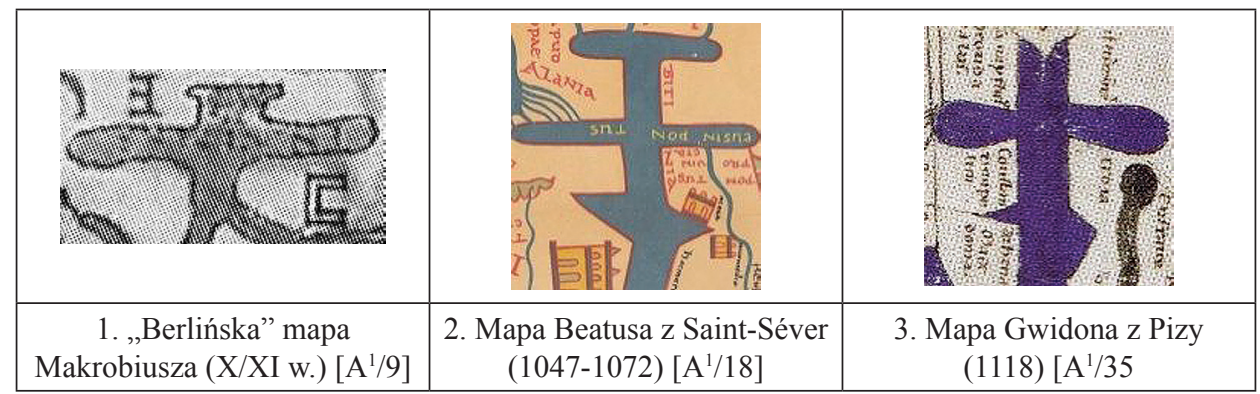

Wśród zachowanych map znajdują się także trzy przykłady, ilustrujące szczególnie dobrze starożytną ideę, w myśl której rzeki są rogami mórz ${ }^{54}$. Przykłady te odnoszą się konkretnie do Dunaju (Ister) i Donu (Tanais), a zatem pojawiają się znowu w kontekście Morza Czarnego ${ }^{55}$. Teoretycznie teze tę można by rozszerzyć na bardzo wiele lub nawet wszystkie średniowieczne mappaemundi oraz na liczne mapy wczesnonowożytne, jednak de facto tylko wspomniane trzy z nich posiadają tak precyzyjnie wykonaną strukturę graficzna, że przypomina ona faktycznie głowę zwierzęcia, z której „wyrastają” owe rzeko-rogi. Jest to łatwo dostrzegalne przede wszystkich w odniesieniu do dwóch pierwszych przykładów, pochodzących znowu z map świata zamieszczonych w kopiach Komentarza do Apokalipsy (Commentarius in Apo-

\footnotetext{
${ }^{54}$ Por. Kochanek, Iluzja schematów choro- $i$ topograficznych, s. 113 i przyp. 200.

${ }^{55}$ Por. tenże, Генезис схематического образа побережья Чёрного моря, s. 23, rys. 16A-C.
} 
calypsin), pióra Beatusa z Liébana (chodzi tym razem o mapę Beatusa z Burgo de Osma (1086) $\left[\mathrm{A}^{1 / 20}\right]$ i o powstałą w końcu XII w. mapę Beatusa z Oña $\left[\mathrm{A}^{1 / 43}\right]$ - tab. II), które jawią się jako autentyczne średniowieczne echo tej antycznej tradycji lub też jako przykład świadomej archaizacji mapy. W literackich źródłach średniowiecznych nie spotyka się wyrażonej expressis verbis tezy, że rzeki to rogi morza. Jest jednak w „Eneidzie” Wergiliusza (15 X 70 - 21 IX 19 p.n.e.), autora niezwykle cenionego, jak wiadomo, w średniowie-

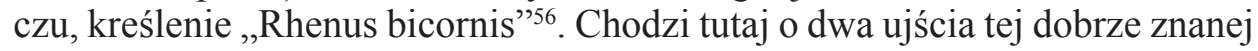
rzymskiej starożytności rzeki. Jest możliwe, że obraz ten był inspiracją dla benedyktyńskich iluminatorów-kartografów, rysujących „Pontus bicornis”, tym bardziej, że to właśnie do tego morza wpadały dwie najbardziej znane rzeki Europy, czyli starożytny Ister i Tanais. Dla głębszego zrozumienia tego zabiegu hiszpańskich benedyktynów należy przyjrzeć się szczególnie uważnie pierwszej mapie, czyli mapie Beatusa z Burgo de Osma $\left[\mathrm{A}^{1 / 20}\right]$, która powstała w roku 1086. Na mapie tej u wejścia na zwieńczone ,rogami” Morze Czarne umieszczono naprzeciw siebie zapewne nieprzypadkowo winiety Konstantynopola i Troi. Winieta Konstantynopola w formie otwartej bramy twierdzy jest przy tym pozbawiona niemal całkowicie symboliki chrześcijańskiej. Jedyną reminiscencją tej symboliki jest tzw. krzyż św. Andrzeja Apostoła, zwany też crux decussata, w kształcie litery X, czyli pierwszej litery słowa

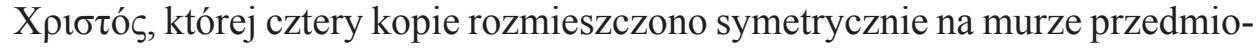
towej bramy po obu stronach otworu bramnego. Ta forma krzyża nawiązuje oczywiście do relikwii św. Andrzeja, spoczywających wówczas w konstantynopolitańskiej Bazylice Apostołów. Z drugiej zaś strony rysunek krzyża na murze bramy sprawia wrażenie, że jest to zaledwie cień krzyża. Natomiast winieta Troi, legendarnej kolebki Rzymu, to również otwarta brama - symbol zdobytego miasta. Bramę tę jednak zdobią trzy identyczne kopuły zwieńczone trzema identycznymi krzyżami - symbol Boga w Trójcy Jedynego, a zatem symbol chrześcijańskiej prawowierności. Warto podkreślić, że w tym przypadku krzyże funkcjonują jako samodzielny element architektoniczny, pełniący rolę zwieńczenia, a zatem najwyższego punktu bramy. W ten sposób „górujące nad” krzyże trojański stoją w wyraźnej opozycji do „narysowanych na" i wtopionych w ściany bramy krzyży św. Andrzeja. Wymowa tego obrazu, który powstał ponad 30 lat po tzw. wielkiej schizmie wschodniej z roku 1054, wydaje się być dość jednoznaczna: „Bez miasta Eneasza nie byłoby [...] Rzy$\mathrm{mu}$, a bez Rzymu nie byłoby np. spełnienia proroctw, zawartych w Księdze Daniela. Bez następstwa imperiów [zaś] nie do pomyślenia była pełnia czasu, wiązana z narodzinami Mesjasza. Troja zatem stoi u początku pewnej sekwencji zdarzeń [...]"57, stanowiąc integralną część historii zbawienia ludzkości.

${ }^{56}$ Vergilius, Aeneis VIII 727, rec. O. Ribbeck: Vergilius, Opera, Lipsiae 1920, 296. Por. L. Weeda - M. van der Poel, Vergil and the Batavians (Aeneid 8.727), „Mnemosyne” 67 (2014) 588-612.

${ }^{57}$ Kochanek, ,, Rozestanie Apostołów” na mapie Beatusa z Burgo de Osma, s. 724. 
Na dodatek Konstantynopol leży po lewej stronie wejścia na Morze Gościnne, podczas gdy Troja zajmuje miejsce po uprzywilejowanej na kartach Biblii prawicy ${ }^{58}$. W tym kontekście schemat morza zwieńczonego dwoma rogami i nieprawowierny Konstantynopol po jego lewej stronie, nabierają wieloznacznej wymowy i ta właśnie wieloznaczność jest siłą tego głęboko symbolicznego schematu, szczególnie jeśli weźmie się pod uwagę czas jego powstania oraz to, że jego twórcami byli najprawdopodobnie benedyktyni z klasztoru Sahagún w Leonie. Jego zaś „opatem od roku 1080 był Bernard de Sédirac (ok. 1050 - 1125), mnich z Cluny, wyniesiony w roku 1086 do godności arcybiskupa Toledo" 59 . Natomiast podobny schemat rzek-rogów na mapie Beatusa z Oña [A ${ }^{1 / 43}$, która powstała w końcu XII w. nie ma już, jak widać (tab. II/2), tej symbolicznej siły ekspresji. Zdaje się to świadczyć o tym, że jego autorzy byli już raczej dalecy od owego ducha polemiki religijnej, albo też starali się go z jakiś przyczyn nie eksponować. Znali jednak zapewne kodeks z Sahagún, o czym świadczy chociażby bardzo podobna wewnętrzna logika mapy opatrzonej tzw. „główkami” Apostołów, tym bardziej że klasztor w Sahagún dzieliło od klasztora w Oña tylko około $140 \mathrm{~km}$. W tym kontekście tzw. mapa Borgia (ok. 1460) jawi się raczej jako rodzaj przypadkowego i być może nieświadomego nawiązania jej autora do antycznej idei, która określała rzeki mianem rogów morza. Jeśli natomiast przyjąć jego świadome działanie, to wypada wskazać na ewidentną chęć archaizacji mapy, jako na motyw działania jej grawera.

Tab. II: Schemat Dunaju i Donu jako „rogów” Morza Czarnego

\begin{tabular}{|c|c|c|}
\hline & \\
\hline
\end{tabular}

Specyficznym rodzajem schematu jest natomiast obszar wypełniony konkretnym kolorem. Na mapach średniowiecznych takim elementem ekumeny było Morze Czerwone, które bardzo długo było zaznaczane barwą, korespondująca z jego nazwą, podczas gdy inne akweny wodne na tej samej mapie posiadały zupełnie inny kolor. Odnosi się to zarówno do większości średniowiecznych map świata, jak i do map morskich, które powstawały już w okresie

${ }^{58}$ Por. O. Nussbaum, Die Bewertung von rechts und links in der römischen Liturgie, JbAC 5 (1962) 159 i 161-162.

${ }^{59}$ Kochanek, , Rozestanie Apostołów” na mapie Beatusa z Burgo de Osma, s. 714. 
wczesnonowożytnym ${ }^{60}$. Ponadto użycie kolorów w kartografii średniowiecznej można uznać także za rodzaj narzędzia mnemotechnicznego, które nawet lepiej niż schemat graficzny wyróżniało dany element mapy i pozwalało na jego szybkie odnalezienie, czyli na łatwą identyfikację.

Pozostając w kręgu schematyzacji związanej z morzem należy zauważyć, że wiele ciekawego materiału dostarcza w tym względzie analiza kształtów wysp.

Do najpopularniejszych w kartografii średniowiecznej schematów należał trójkąt wyobrażający Sycylię. Schemat ten koresponduje z rzeczywistym kształtem wyspy i można przyjąć, że był on znany żeglarzom od niepamiętnych czasów ${ }^{61}$. Ideę tę przejęli poczytni w średniowieczu autorzy rzymscy m.in. Pliniusz ${ }^{62}$ i Marcjanus Kapella ${ }^{63}$, a następnie wielkie autorytety (m.in. geo- i kartograficzne) średniowiecza: Orozjusz ${ }^{64}$, Izydor z Sewilli (ok. 560 - 4 IV 636) ${ }^{65}$, Raban Maur (ok. 780 - 4 II 856) ${ }^{66}$, Honoriusz z Autun (ok. 1080 - ok. 1150) ${ }^{67}$ i Gerwazy z Tilbury (ok. 1150 - ok. 1235) ${ }^{68}$. W ten sposób określenie „Trinacria” zostało utrwalone nie tylko na kartach kodeksów, lecz także na mapach. Poniższa tabela (tab. III) zawiera de facto schematy Sycylii widniejące na trzech typach map średniowiecznych. Najważniejsze z punktu widzenia tematu niniejszego artykułu są tzw. mapy świata (mappaemundi). W tym przypadku zestawienie poniższe ujmuje trójkątne schematy Sycylii na wszystkich zachowanych mapach średniowiecznych, należących do tej kategorii (tab. III, rys. 1-2, 4, 6 i 8-12). Drugim typem są tzw. mapy Makrobiusza, zwane też mapami strefowymi. Jednak mapy te są zwykle bardzo małe, a ich reprodukcje słabo czytelne. Z tego powodu wybrano tylko kilka przykładowych trójkątnych schematów Sycylii, widniejących na rzeczonych mapach (tab. III, rys. 3, 5 i 7). Trzecią grupa map reprezentowanych w niniejszej tabeli są wczesnonowożytne mapy świata (tab. III, rys. 13-16).

${ }^{60}$ Por. Brincken, Die Ausbildung konventioneller Zeichen und Farbgebungen, tablica między s. 336 a 337 (= taż, Studien zur Universalkartographie des Mittelalters, s. 124).

${ }^{61}$ Por. Kochanek, Iluzja schematów choro- $i$ topograficznych, s. 80-82 i przyp. 28-35. Tutaj zostały przeanalizowane liczne źródła antyczne i średniowieczne dotyczące tej kwestii. Por. G.F. Chiai, Il nome della Sardegna e della Sicilia sulle rote dei Fenici e dei Greci in età arcaica. Analisi di una tradizione storico-letteraria, „Rivista di Studi Fenici” 30 (2002) nr 2, 134-135, 142 i 145-146. Należy pamiętać, że w przypadku włoskiej literatury przedmiotu, która w Polsce jest raczej trudno dostępna, nawiązania do tego schematu wyspy są bardzo często, ponieważ jest to integralna część ich dziedzictwa kulturowego.

${ }^{62}$ Plinius, Naturalis historia III 86, rec. Mayhoff, vol. 1, s. 265, 13.

${ }^{63}$ Martianus Capella, De nuptiis Philologiae et Mercurii VI 585, ed. J. Willis: Martianus Capella, De nuptiis Philologiae et Mercurii, Leipzig 1983, 205, 21; tamże, VI 646, ed. Willis, s. 225, 13 i 16-17.

${ }^{64}$ Orosius, Historia adversus paganos I 2, 99, CSEL 5, s. 37, 3 (= PL 31, 695A).

${ }^{65}$ Isidorus Hispalensis, Etymologiae XIV 6, 32, PL 82, 517C-518A.

${ }^{66}$ Rabanus Maurus, De universo XII 5, PL 111, 357A.

${ }^{67}$ Honorius Augustodunensis, Imago mundi I 34, ed. Flint, s. 65 (= PL 172, 132A).

${ }^{68}$ Gervasius Tilleberiensis, Otia imperialia II 12, ed. Banks - Binns, s. 332. Na gruncie polskim najbardziej znaną i ważną pracą poświęconą Gerwazemu jest monografia pióra Jerzego Strzelczyka (Gerwazy z Tilbury. Studium z dziejów uczoności geograficznej w średniowieczu, Monografie z Dziejów Nauki i Techniki 66, Wrocław - Warszawa 1970). 
Również tutaj dokonano selekcji zachowanych map, dzieląc je jednocześne na dwie podgrupy. Pierwsza podgrupa składa się z tzw. mapy Genueńskiej (tab. III, rys. $13=\mathrm{A}^{1 / 71}$ ) i mapy Fra Mauro (tab. III, rys. $14=\mathrm{A}^{1 / 72}$ ). Mapy te sa przykładami przedstawiania Sycylii w jej niemal dziś znanym kształcie, ponieważ ich autorzy oparli się na współczesnych im mapach morskich, które nie posługiwały się schematami, lecz dążyły do oddanie realnej formy wyspy ${ }^{69}$. Ten nurt funkcjonował w kartografii przynajmniej od końca XIII w., a wpierały go również mapy oparte na zasadach kartografii ptolemejskiej ${ }^{70}$. Drugą podgrupe reprezentuje mapa Borgia (tab. III, rys. $15=\mathrm{A}^{1 / 73}$ ) i mapa z Zeitz (tab. III, rys. $16=\mathrm{A}^{1 / 74}$ ). Są to przykłady wczesnowożytnych mapy świata, które mimo zaawansowanej już wówczas wiedzy na temat m.in. Sycylii, kultywowały nadal dawne formy schematyzacji. Mapy te cechuje zatem świadoma archaizacja.

Jak łatwo dostrzec, na zachowanych średniowiecznych mapach świata (tab. III, rys. 1-2, 4, 6 i 8-12) nie zawsze Sycylia ma schemat trójkąta. Wyjątek w tym względzie stanowi bowiem mapa z Albi (tab. III, rys. $2=\mathrm{A}^{1} / 2$ ), który przedstawia rzeczoną wyspę w formie rombu (a zatem w formie dwóch trójkątów o wspólnej podstawie?). Natomiast mapa z Ebstorf (tab. III, rys. $11=\mathrm{A}^{1 / 54}$ ) stylizuje sycylijski trójkąt, nadając mu de facto realny kształt serca. Generalnie jednak można powiedzieć, że mapy wyróżnionego wyżej pierwszego typu pozostawały wierne „zaleceniom” wspomnianych już autorytetów w kwestii schematyzacji Sycylii. Podobnie zresztą grosso modo zachowywali się autorzy map strefowych, choć zwykle na ich małych kartogramach nie było miejsca na graficzne przedstawienie jakiejkolwiek wyspy. Ten prosty schemat trójkątnej Sycylii był łatwy do zapamiętania. $\mathrm{Z}$ tego powodu wyspa ta była prawdopodobnie najlepiej znana (wyedukowanej części społeczeństwa Europy) wyspą Morza Śródziemnego. Warto również zauważyć, że tego schematu nie posiada żadna z zachowanych map Beatusa, choć znajduje się on w dziełach Orozjusza i Izydora z Sewilli. Należy także zatrzymać się chwilę nad trójkątnym schematem Sycylii znajdującym się na tzw. Cottonianie (tab. III, rys. $4=\mathrm{A}^{1 / 15}$ ) i na mapie z Psałterza Londyńskiego (tab. III, rys. $10=\mathrm{A}^{1 / 52}$ ). Widoczne tam bowiem kształty wyspy wyróżniają się spośród innych mocno „falistą” linią brzegową. Linia ta zdaje się sugerować dużą liczbę zatok, a co za tym idzie dużą liczbę dogodnych dla żeglarzy przystani. W ten sposób Sycylia jest niejako „reklamowana” jako wyspa przyjazna ludziom morza, która niemal w geograficznym środku Morza Śródziemnego może zapewnić im wytchnienie. Z kolei inne średniowieczne mappae

${ }^{69}$ Już mapy Pietro Vesconte (floruit: 1310-1330) nie schematyzują ani Sycylii ani Sardynii, lecz starają się zarysować ich realne kształty, por. Pietro Vesconte, Seekarten, Mit einem Geleitwort von O. Mazal. Einführung von L. Pagani, Würzburg 1978, mapa nr 7. Chodzi tutaj o przykładową mapę, która znajduje się w jednym z jego zachowanych atlasów: Wiedeń, Österreichische Nationalbibliothek, Codex 594, Tafel VI (wielkość oryginału rzeczonej mapy: 195 x $185 \mathrm{~mm}$; data powstania: 1318). Ten właśnie atlas został wydany przez Otto Mazala (26 II 1932 - 23 VI 2008) i Lelio Paganiego (1943 - 22 I 2006).

${ }^{70}$ Por. P. Gautier Dalché, La Géographie de Ptolémée en Occident (IVE-XVIe siècle), Terrarum Orbis 9, Turnhout 2009, passim. 
mundi, takie jak Wiktoryńska mapa ekumeny (tab. III, rys. $6=\mathrm{A}^{1 / 25}$ ), mapa z Ebstorf (tab. III, rys. $11=\mathrm{A}^{1} / 54$ ), mapa z Hereford (tab. III, rys. $12=\mathrm{A}^{1} / 55$ ) oraz znacznie od nich późniejsza mapa Fra Mauro (tab. III, rys. $14=\mathrm{A}^{1 / 72}$ ), zapełniają wyspę winietami miast, co zapewne ma podkreślać wysoki stopień jej zurbanizowania, a co za tym idzie dobre przygotowanie do obrony. Poza tym obecność miast na wyspie może wskazywać na jej walory kulturowe oraz na znaczenie Sycylii w tranzytowym handlu śródziemnomorskim. W tym sensie winiety te należy traktować jako swego rodzaju kod kartograficzny.

Trzeba też zauważyć, że mieszkańcy Sycylii są bardzo przywiązani do owego antycznego schematu trójkąta, jako niemal naturalnego symbolu wyspy, i to do tego stopnia, że tzw. "Triscele di Sicilia” stało się w roku 2000 integralną częścią flagi tej wyspy ${ }^{71}$.

Tab. III: Trójkątny kształt Sycylii.

\begin{tabular}{|c|c|c|c|}
\hline $\begin{array}{c}\text { 1. Watykańska mapa } \\
\text { Izydora (ok. 775) } \\
{\left[\mathrm{A}^{1 / 1}\right]}\end{array}$ & $\begin{array}{l}\text { 2. Mapa z Albi } \\
\text { (IX w.) }\left[\mathrm{A}^{1 / 2}\right]\end{array}$ & $\begin{array}{l}\text { 3. „Berlińska” mapa } \\
\text { Makrobiusza } \\
\text { (X/XI w.) }\left[\mathrm{A}^{1 / 9}\right]\end{array}$ & $\begin{array}{c}\text { 4. Cottoniana } \\
\text { (ok. 1030) }\left[\mathrm{A}^{1 / 15}\right]\end{array}$ \\
\hline & 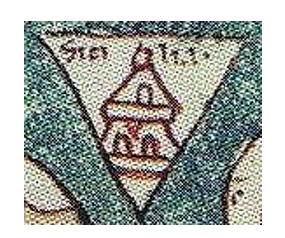 & 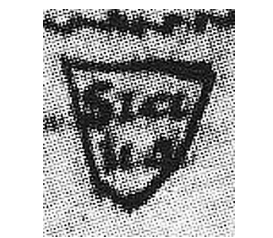 & 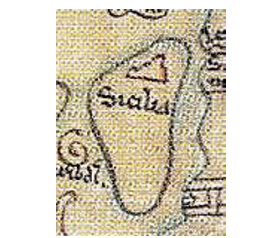 \\
\hline $\begin{array}{c}\text { 5. Mapa Makrobiusza } \\
\text { z Fryzyngi (XI w.) } \\
{\left[\mathrm{A}^{1 / 21}\right]}\end{array}$ & $\begin{array}{c}\text { 6. Wiktoryńska mapa } \\
\text { ekumeny (XI/XII w.) } \\
{\left[\mathrm{A}^{1 / 25}\right]}\end{array}$ & $\begin{array}{c}\text { 7. „Paryska” mapa } \\
\text { Makrobiusza II } \\
{\left[\mathrm{A}^{1 / 26}\right]}\end{array}$ & $\begin{array}{l}\text { 8. Mapa z Sawley } \\
(1110 / 1180)[A 1 / 32]\end{array}$ \\
\hline 3 Ine & 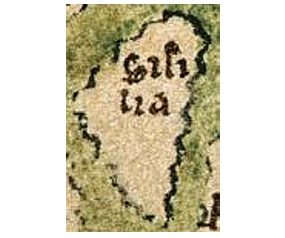 & 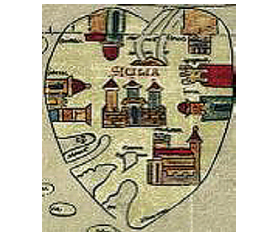 & \\
\hline $\begin{array}{c}\text { 9. Mapa Europy } \\
\text { Zachodniej Geralda } \\
\text { z Walii (ok. 1200) } \\
{\left[\mathrm{A}^{1 / 45]}\right.}\end{array}$ & $\begin{array}{l}\text { 10. Mapa z Psałterza } \\
\text { Londyńskiego } \\
\text { (ok. 1260) }\left[\mathrm{A}^{1 / 52}\right]\end{array}$ & $\begin{array}{l}\text { 11. Mapa z Ebstorf } \\
\text { (ok. 1300) }\left[\mathrm{A}^{1 / 54}\right]\end{array}$ & $\begin{array}{l}\text { 12. Mapa } z \text { Hereford } \\
(1276 / 1305)\left[\mathrm{A}^{1 / 55}\right]\end{array}$ \\
\hline
\end{tabular}

${ }^{71}$ Por. Kochanek, Iluzja schematów choro- $i$ topograficznych, s. 89. 


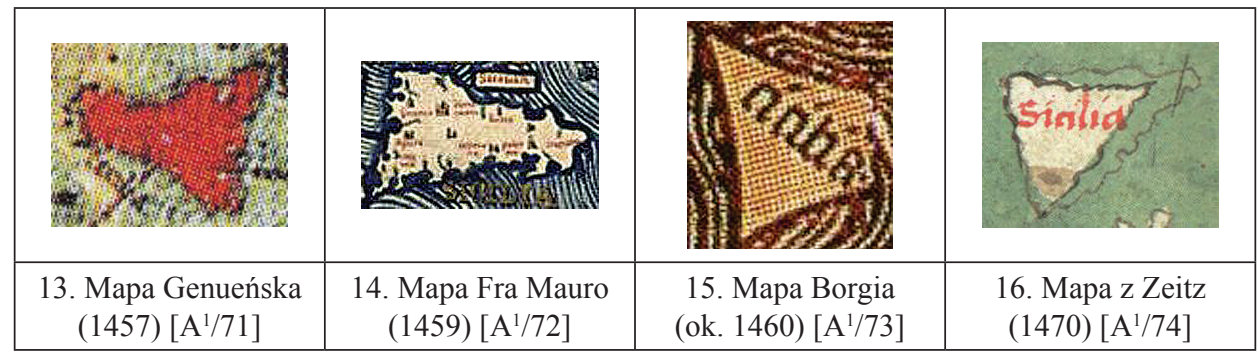

Z kolei Sardynia w greckich źródłach antycznych jest porównywana do ludzkiej stopy ${ }^{72}$. Schemat ten przejęła literatura rzymska, m.in. Pliniusz ${ }^{73}$ i Marcjanus Kapella ${ }^{74}$, a przekazali zachodniemu średniowieczu Izydor z Sewilli $^{75}$ i Raban Maur ${ }^{76}$. Warto jednak wczytać się głębiej w teminologię łacińską, stosowaną przez wymienionych autorów. Wówczas zaś okaże się, że kwestia schematu wyspy jest nieco bardziej zniuansowana. I tak Pliniusz określa kształt Sardynii mianem ,effigies soleae”, a zatem jako „odcisk sandała”. Z kolei Marcjanus Kapella użył pojęcia „planta humana” - „ludzka stopa”. Natomiast w tekście Izydora z Sewilli i Rabana Maura widnieje zwrot ,vestigium humanum”, ,ślad ludzkiej stopy”. Kartografowie średniowieczni, chcąc podążyć za tymi wskazówkami musieli doświadczać pewnej rozterki, co pokazuje poniższa tabela (tab. IV). Idąc bowiem za tymi rozbieżnymi w sferze detali autorytetami, przenieśli powyższy kształt na swoje mapy w sposób, który świadczy o uważnej lekturze wspomnianych wyżej autorów. Za autorytetem Pliniusza poszli wyraźnie twórcy mapy z Sawley (tab. IV, rys. $2=\mathrm{A}^{1 / 32}$ ) i mapy $\mathrm{z}$ Hereford (tab. IV, rys. $5=\mathrm{A}^{1 / 55}$ ) oraz dokonujący prawdopodobnie świadomej archaizacji swego dzieła autor tzw. mapy Borgia (tab. IV, rys. $6=\mathrm{A}^{1 / 73}$ ), nadając Sardynii kształt „odcisku sandała”. Odcisk ten został nawet w dwóch pierwszych przypadkach precyzyjnie określony: na mapie z Sawley $\left[\mathrm{A}^{1 / 32}\right]$ chodzi o odcisk prawego sandała, podczas gdy na mapie $\mathrm{z}$ Hereford $\left[\mathrm{A}^{1} / 55\right]$ jest to sandał wkładany na lewą stopę. $Z$ kolei za autorytetem Marcjanusa Kapelli, Izydora z Sewilli i Rabana Maura poszedł średniowieczny kopista Tabu-

${ }^{72}$ Zestawienie źródeł zarówno greckich jak i łacińskich znajduje się w: Kochanek, Iluzja schematów choro- $i$ topograficznych, s. 110, przyp. 186. Por. Chiai, Il nome della Sardegna e della Sicilia, s. 138-139 i 142-143; P. Bernardini, Gli eroi e le fonti, w: $\Lambda$ ОГО $\Sigma$ ПЕРI ТН $\Sigma \Sigma$ АР $\triangle \mathrm{OY} \Sigma$. Le fonti classiche e la Sardegna, Atti del Convegno di Studi - Lanusei, 29 dicembre 1998, a cura di R. Zucca, Roma 2004, 41-42, 52 i 55; C. Milani, Sardinia in testi latini medievali, „Il Nome nel Testo" 11 (2009) 67-69, 70 i 71-72. Podobnie jak w przypadku Sycylii we włoskiej literaturze fachowej równie często powraca motyw antycznych schematów Sardynii, por. przyp. 61.

${ }^{73}$ Plinius, Naturalis historia III 85, rec. Mayhoff, vol. 1, s. 265, 6: effigies soleae, Ichnusa, Sandaliotes.

${ }^{74}$ Martianus Capella, De nuptiis Philologiae et Mercurii VI 645, ed. Willis, s. 225, 3-4: humana planta, Ichnusa, Sandaliotes.

${ }^{75}$ Isidorus Hispalensis, Etymologiae XIV 6, 39, PL 82, 519A: vestigium humanum.

${ }^{76}$ Rabanus Maurus, De universo XII 5, PL 111, 357D-358A: Ichnos, vestigium humanum. 
la Peutingeriana (tab. IV, rys. $3=\mathrm{A}^{1} / 44$ ) i twórcy mapy z Ebstorf (tab. IV, rys. $4=\mathrm{A}^{1 / 54}$ ). Również i w tym przypadku autorzy poszli o krok dalej precyzując jasno, o którą stopę chodzi: kopista Tabula Peutingeriana narysował więc lewą stopę, gdy tymczasem mapa z Ebstorf przedstawia stopę prawą. Osobną sprawą jest schemat Sardynii widniejący na tzw. Watykańskiej mapie Izydora (tab. IV, rys. $1=\mathrm{A}^{1} / 1$ ), która powstała około roku 775 . Wyspa ta nie przypomina bowiem tutaj w niczym ludzkiej stopy. Przywodzi raczej na myśl uzbrojoną w cztery pazury łapę wilka lub łapę lwa, która jest zorientowana na Wschód. Richard Uhden (1 IV 1900 - 1 VIII 1939) stwierdził po prostu: ,[...] der Fusssohlengestalt Sardiniens entspricht ganz der Ausdrucksweise des Plinius (III 85-86)" "77. Badacz ten nie porównał jednak tego schematu z kształtem Sardynii na innych zachowanych średniowiecznych mapach świata. Gdyby to uczynił najprawdopodobnie nie rozstrzygnąłby tej kwestii tak jednoznacznie, lecz pozostawił ją otwarta, ponieważ porównawczy materiał ikonograficzny nie pozwala na takie uproszczenie. Być może autor mapy oparł się na jakimś nieznanym dziś wzorze, który wiązał symbolicznie Sardynię ze Wschodem. Można by sugerować, że owym lwem sardyńskim był Lucyferiusz z Cagliari (zm. ok. 370), nieprzejednany w walce $\mathrm{z}$ arianizmem, czyli herezją powstała we wschodniej części cesarstwa, który jednak później sam stał się heterodoksem i został potępiony, a zatem uznany za wilka w kościelnej owczarni. Poszukiwanie tego typu wyjaśnienia usprawiedliwia do pewnego stopnia wewnętrzna logika tzw. Watykańskiej mapy Izydora, która ma głęboko chrześcijański charakter. Jednak „drapieżność” tego schematu można wythumaczyć również w inny sposób. Otóż wiadomo, że wyspa w latach 703/704-1014 była częstym obiektem ataków muzułmańskich ${ }^{78}$. Zatem autor mapy, która powstała w około roku 775, mógł świadomie zamienić kształt ludzkiej stopy na schemat łapy drapieżnika, chcąc w ten sposób sugestywnie oddać ducha walki chrześcijańskich mieszkańców Sardynii.

Jednak, jak wynika z poniższej tabeli, schemat ten nie zdominował map tego okresu, jak to miało miejsce w przypadku sycylijskiego trójkąta. Ze względu na podnoszoną już wcześniej wielkość zachowanych map, tylko na trzech z nich Sardynia została zaopatrzona w obszerniejsze legendy lub winiety. Tabula Peutingeriana podaje siedem toponimów, do których dołącza jedną winietę. Z kolei mapa z Ebstorf, prócz pięciu winiet miast, posiada nad schematem ludzkiej stopy częściowo już zatartą legendę w prostokątnej ramce, która brzmi: ,Sardinia Sandaliotes dicta quod in modum humani vestigii sit $[. . .]^{\text {"79 }}$. Natomiast na mapie $\mathrm{z}$ Hereford wyspa została zaopatrzona w cztery winiety miast oraz

\footnotetext{
${ }^{77}$ R. Uhden, Die Weltkarte des Isidorus von Sevilla, „Mnemosyne” series III, 3 (1936) 21.

${ }^{78}$ Por. Die Ebstorfer Weltkarte. Kommentierte Neuausgabe in zwei Bänden. Band II: Untersuchungen und Kommentar, s. 266 (47/32).

${ }^{79}$ Tekst legendy za: Die Ebstorfer Weltkarte, Bd. I, s. 122 (47 B1/32). Por. Sommerbrodt, Die Ebstorfer Weltkarte, [Teil: Text], s. 63, 36; Miller, Mappaemundi. Die ältesten Weltkarten, V. Heft, s. 30. Komentarz: Die Ebstorfer Weltkarte, Bd. II, s. 266 (47/32).
} 
w następującą legendę, wpisaną w „odcisk sandała”: „Sardinia: Grece ‘Sandaliotes' dicta a similitudine pedis humani. Ab oriente [patet] centum octoginta octo [milia] passuum, ab occidente centum octoginta quinque milia, a meridie septuaginta septem milia, a septemtrione centum viginti milia"80. Legendy te potwierdzają wpływ wymienionych wyżej autorytetów na twórców schematu Sardynii, jednak, jak widać, każdy z nich wybrał inny aspekt: bosą stopę i stopę ubraną w trzewik, którego krój koresponduje bez wątpienia z gustami epoki.

Tab. IV: Stopa ludzka - schemat Sardynii

\begin{tabular}{|c|c|c|}
\hline (2) & Dy $\quad r z$ & 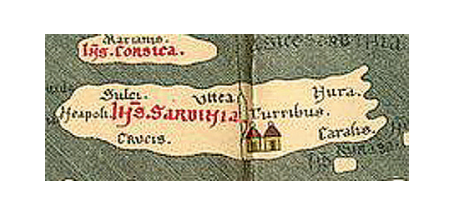 \\
\hline $\begin{array}{l}\text { 1. Watykańska mapa Izydora } \\
\text { (ok. 775) }\left[\mathrm{A}^{1 / 1}\right]\end{array}$ & $\begin{array}{l}\text { 2. Mapa z Sawley } \\
(1110 / 1180)\left[\mathrm{A}^{1 / 32}\right]\end{array}$ & $\begin{array}{c}\text { 3. Tabula Peutingeriana } \\
\text { (IV w.; kopia: XII/XIII w.) }\left[\mathrm{A}^{1 / 44]}\right.\end{array}$ \\
\hline 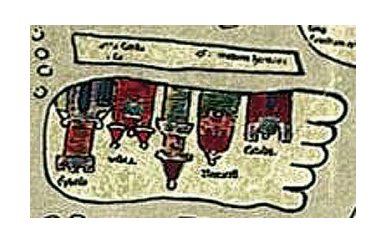 & 8 & 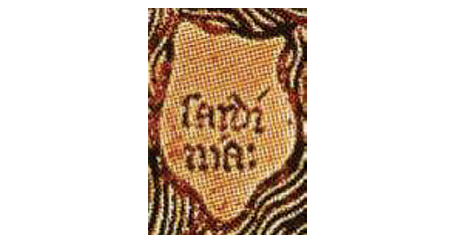 \\
\hline $\begin{array}{l}\text { 4. Mapa z Ebstorf } \\
\text { (ok. 1300) }\left[\mathrm{A}^{1} / 54\right]\end{array}$ & $\begin{array}{l}\text { 5. Mapa z Hereford } \\
(1276 / 1305)\left[\mathrm{A}^{1 / 55}\right]\end{array}$ & $\begin{array}{l}\text { 6. Mapa Borgia } \\
\left(\text { ok. 1460) }\left[\mathrm{A}^{1 / 73}\right]\right.\end{array}$ \\
\hline
\end{tabular}

Inny schemat antyczny odnoszący się do wysp, który był niekiedy powielany przez kartografów średniowiecznych, zawierało w swej etymologii pojęcie „Cyklady”. Termin ten to niemal „naturalna” nazwa, którą zapewne od niepamiętnych czasów żeglarze greccy określali grupę wysp Morza

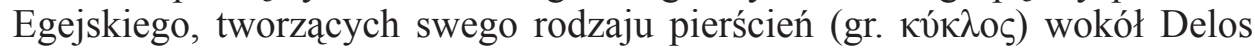
- świętej wyspy Apollina ${ }^{81}$. W zachowanej rzymskiej spuściźnie literackiej aspekt ten podkreślał Pliniusz ${ }^{82}$, a po nim Solinus (III w.) ${ }^{83}$ i Marcjanus

${ }^{80}$ Tekst legendy za: S.D. Westrem, The Hereford Map. A Transcription and Translation of the Legends with Commentary, Terrarum Orbis 1, Turnhout 2001, 421 (nr 1075). Por. W.L. Bevan - H.W. Phillott, Mediaeval Geography: An Essays in Illustration of the Hereford Mappa Mundi, London 1873 [reprint: Amsterdam 1969], 118; K. Miller, Mappaemundi. Die ältesten Weltkarten, IV. Heft: Die Herefordkarte, Stuttgart 1896, 21. Komentarz: Westrem, The Hereford Map, s. 420 (nr 1075).

${ }^{81}$ Por. Kochanek, Iluzja schematów choro- $i$ topograficznych, s. 77. Zestawienie źródeł antycznych na temat schematu Cyklad, tamże, s. 78, przyp. 11. Por. też tamże, s. 120-121 i przyp. 230.

${ }^{82}$ Plinius, Naturalis historia IV 65, ed. Mayhoff, vol. 1, s. 327, 15 - 328, 2: „[...] multae [...] circa Delum in orbem sitae, unde et nomen traxere, Cyclades".

${ }^{83}$ Solinus, Collectanea rerum memorabilium 11, 17, rec. T. Mommsen: Solinus, Collectanea 
Kapella $^{84}$. Przejęli zaś i rozpropagowali ten schemat Izydor z Sewillii ${ }^{85}$, Raban Maur $^{86}$, Honoriusz z Autun ${ }^{87}$ i Gerwazy z Tilbury ${ }^{88}$. Jednakże w kartografii średniowiecznej schemat ów był stosowany bardzo rzadko nawet na mapach, których wielkość pozwalała na jego użycie (tab. V). Pojawia się on prawdopodobnie na Cottonianie (tab. V, rys. $1=\mathrm{A}^{1 / 15}$ ), choć brak tam jakiejkolwiek legendy, a ponadto wyspy te nie tworzą na tej mapie charakterystycznego schematu pierścienia. Natomiast mapa z Sawley (tab. V, rys. $2=\mathrm{A}^{1 / 32}$ ) nie pozostawia już wątpliwości o jakie wyspy chodzi, ponieważ schemat ten przedstawiono zarówno graficznie, jak i opatrzono legendą: „Cyclades insu-

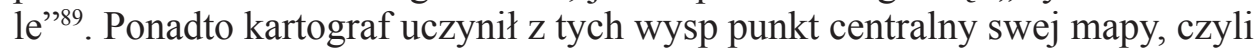
umbilicus mundi. Z kolei mapa z Hereford (tab. V, rys. $4=\mathrm{A}^{1 / 55}$ ) nie wyeksponowała aż tak bardzo Cyklad, jednak jej twórca pozostał wierny wielkim autorytetom, opatrując swój schemat tych wysp następującą legendą: „Delos insula in medio Cicladum situs [sic!]. Sunt autem Ciclades quinquaginta tres. A septemtrione in meridiem septingenti - ab orient[e] in occasum ducenti miliaria habent" " Zatem mimo „popularności” powyższego schematu w źródłach pisanych, kartografia średniowieczna nie podzielała tego entuzjazmu. De facto bowiem tylko mapa z Hereford przejęła sakramentalną niemal formułę literacką: „Delos insula in medio Cicladum sita”. Osobny przypadek to mapa $\mathrm{z}$ Ebstorf (tab. V, rys. $3=\mathrm{A}^{1} / 54$ ). Mapa ta nie posiada graficznego przedstawienia Cyklad, natomiast w prostokattnej ramce zawiera dwie legendy, które niejako skrypturystycznie schematyzują te wyspy: 1. „Hic Cyclades insule [in] Hellesponto Mirtooque mari circumdantur. Metropolis earum

rerum memorabilium, ed. 2, Berolini 1958, 83, 8-11: „Cyclades [...] in orbem [...] circa Delum sitae sunt, et orbem cyclon Graii loquuntur".

${ }^{84}$ Martianus Capella, De nuptiis Philologiae et Mercurii VI 660, ed. Willis, s. 233, 10-11: „In Myrtoo autem mari Cyclades, quarum notiores Delos et Antandros, quae nomina a circulata ordinatione sortitae".

${ }^{85}$ Isidorus Hispalensis, Etymologiae XIV 6, 19, PL 82, 516A: „Cyclades insulae [...] in orbem

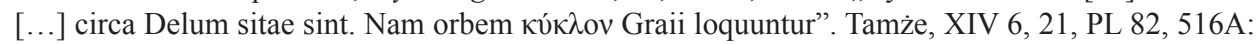
„Delos insula in medio Cycladum sita”.

${ }^{86}$ Rabanus Maurus, De universo XII 5, PL 111, 356A: „Cyclades insulae [...] in orbem [...] circa Delum sitae sint. Nam orbem cyclon Graeci loquuntur. [...]. Delos insula in medio Cycladum sita”.

${ }^{87}$ Honorius Augustodunensis, Imago mundi I 33, ed. Flint, s. 64 (= PL 172, 131C-D): „Ciclades dicuntur quod in rotundo sint positę, ciclon enim orbis dicitur. [...]. Delos in medio Cicladum est sita”.

${ }^{88}$ Gervasius Tilleberiensis, Otia imperialia II 12, ed. Banks - Binns, s. 328: „Ciclades insule dicuntur quod in rotundo sunt posite: ciclon enim Grece 'orbis' Latine”; tamże, II 12, ed. Banks - Binns, s. 330: „Delos in medio Cicladum est sita [...]”.

${ }^{89}$ Tekst legendy za: D. Lecoq, La mappemonde d'Henri de Mayence ou l'image du monde au $X I I^{e}$ siècle, w: Iconographie médiévale. Image, texte, contexte, sous la dir. de G. Duchet-Suchaux, Paris 1990, 162 (nr 203). Por. Miller, Mappaemundi. Die ältesten Weltkarten, III. Heft, s. 27.

${ }^{90}$ Tekst legendy za: Westrem, The Hereford Map, s. 399 (nr 1013). Por. Bevan - Phillott, Mediaeval Geography, s. 113-114; Miller, Mappaemundi. Die ältesten Weltkarten, IV. Heft, s. 22. Komentarz: Westrem, The Hereford Map, s. 398 (nr 1013). 
pene...Rodus" ${ }^{91} ; 2$. „Delos insula in medio earum. Ipsa est et Ortigia, quia in ea primitus coturnices invise sunt, quos Greci ortigas vocant. Ipsa est civitas et insula"92. Ponadto do nich nawiązuje także legenda wpisany w ,kroplokształtny” zarys wyspy Rodos, znajdujący się po prawej stronie owej prostokątnej ramki: „Rodos est metropolis Cycladarum insularum fecundissima"93. Można zatem powiedzieć, że obraz został tu zastąpiony słowem, które dochowało wierności schematyzacji antycznej.

Tab. V: Schemat Cyklad

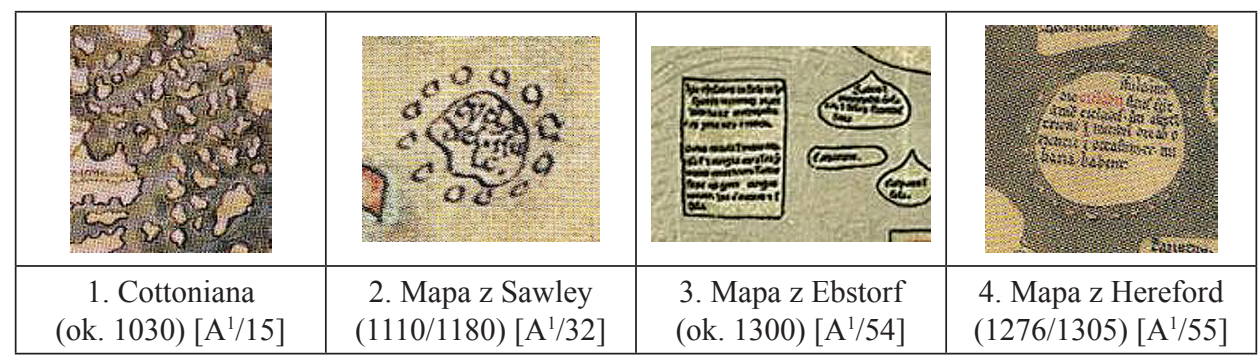

Z kolei Orcades (tab. VI) to w tradycji literackiej zwykle 33 lub 34 wyspy położone w sąsiedztwie Brytanii, a zatem wyspy, które flankowały ekumenę od północnego-zachodu. Pojawiają się one niemal we wszystkich źródłach geograficznych antyku i średniowiecza. Jednak mimo tak długiej i bogatej tradycji Orkady nie doczekały się żadnego schematu. Tymczasem w kartografii średniowiecznej stały się swego rodzaju alter ego Cyklad. Widać to w sposób szczególny na trzech przykładach: na Cottonianie (tab. VI, rys. $5=\mathrm{A}^{1 / 15}$ ), na mapie z Sawley (tab. VI, rys. $10=\mathrm{A}^{1 / 32}$ ) oraz na mapie z Hereford (tab. VI, rys. 18 $=\mathrm{A}^{1 / 55}$ ). W przypadku tych map łatwo dostrzec symetryczne rozmieszczenie Orkad i Cyklad względem Europy. Cyklady bowiem zostały tu zlokalizowane po południowo-wschodniej stronie kontynentu, natomiast Orkady po jego stronie północno-zachodniej. Jednak na Cottonianie Orkady, w przeciwieństwie do wspomnianych wyżej Cyklad, posiadają legendę: „Orcades insule”"94, której pojedyncze litery zostały wpisane $\mathrm{w}$ poszczególne wysepki. W ten prosty spo-

${ }^{91}$ Tekst legendy za: Die Ebstorfer Weltkarte, Bd. I, s. 108 (40 A1/1). Por. Sommerbrodt, Die Ebstorfer Weltkarte, [Teil: Text], s. 61, 28-29; Miller, Mappaemundi. Die ältesten Weltkarten, V. Heft, s. 28. Komentarz: Die Ebstorfer Weltkarte, Bd. II, s. 219 (40/1).

${ }_{92}$ Tekst legendy za: Die Ebstorfer Weltkarte, Bd. I, s. 108 (40 A1/4). Por. Sommerbrodt, Die Ebstorfer Weltkarte, [Teil: Text], s. 61, 29-31; Miller, Mappaemundi. Die ältesten Weltkarten, V. Heft, s. 28. Komentarz: Die Ebstorfer Weltkarte, Bd. II, s. 219-220 (40/4).

${ }^{93}$ Tekst legendy za: Die Ebstorfer Weltkarte, Bd. I, s. 108 (40 A2/14). Por. Sommerbrodt, Die Ebstorfer Weltkarte, [Teil: Text], s. 62, 1; Miller, Mappaemundi. Die ältesten Weltkarten, V. Heft, s. 28. Komentarz: Die Ebstorfer Weltkarte, Bd. II, s. 221 (40/14).

${ }^{94}$ Tekst legendy za: Miller, Mappaemundi. Die ältesten Weltkarten, III. Heft, s. 32. Por. E. Cortambert, Quelques-uns des plus anciens monuments géographique du Moyen Âge conservés à la Bibliothèque Nationale, „Bulletin de la Société de Géographie” 6 Ser., 14 (1877) 356. 
sób autor mapy poradził sobie z problem braku miejsca. Natomiast ich podobieństwo do domniemanych Cyklad zasadza się na analogicznym braku charakterystycznego schematu pierścienia. Inaczej ma się rzecz na mapie z Sawley, gdzie obok owego charakterystycznego schematu pierścienia widnieje legenda „Orcades" ${ }^{95}$, nie pozostawiając żadnej wattpliwości o jakie wyspy chodzi, podobnie jak w przypadku Cyklad. Bardzo podobnie przedstawia się ta sprawa także na mapie z Hereford, która posiada nie tylko ów pierścień wysepek wokół centralnie położonej głównej, choć anonimowej wyspy archipelagu, lecz także legendę: „Orcades insulee trigintaquatuor [sic!]”96. Poza tymi trzema przykładami wspomnianego wyżej symetrycznego rozmieszczenia Cyklad i Orkad względem Europy idea ta nie pojawia się w formie graficznej na pozostałych zachowanych mapach. Natomiast mapa z Ebstorf, jak pokazano wyżej, symetrię graficzną zastąpiła zespołem legend. $Z$ kolei schemat Orkad (ale bez Cyklad) podobny do tego z Cottoniany widnieje na mapie Europy Zachodniej Geralda z Walii (tab. VI, rys. $14=\mathrm{A}^{1 / 45}$ ). Natomiast schemat Orkad przypominający ten z mapy z Sawley i mapy z Hereford jest obecny na mapie z Ebstorf (tab. VI, rys. $17=\mathrm{A}^{1 / 54}$ ) oraz na mapie Brytanii Mateusza Paris (tab. VI, rys. $16=\mathrm{A}^{1 / 51}$ ). Na tej pierwszej towarzyszy mu następująca legenda: „Orcades insule XXXIIII quarum $X X$ deserte sunt ${ }^{\prime 97}$. Z kolei mapa Brytanii określa te wyspy krótko: „Insule Orkadum [sic!]"98.

Zupełnie innym problem związany z tymi wyspami pojawia się ma tzw. mapach Makrobiusza (tab. VI, rys. 1-4, 6-9, 11-13 i 15). Z dużej liczby zachowanych map tego typu zostały tutaj wybrane tylko te, które najlepiej ilustrują poniższe zagadnienie. Jak wiadomo mapy makrobiańskie ze względu na mały format przedstawiają zwykle Morze Śródziemne w formie wąskiego paska, na którym widnieje niekiedy maleńka Sardynia, Sycylia lub Kreta, jednak nie ma tam możliwości narysowania innych wysp tego akwenu. Natomiast na oceanicznej „lamówce” tych map, na jej najdalszych zachodnich kresach przedstawiano niekiedy właśnie Orkady w formie okręgu-pierścienia, opatrując go dobrze widoczną legenda - „Orcades”. Maniera ta jest uchwytna przynajmniej od przełomu X/XI w., czyniąc z nich symbol, który można by określić mianem alter orbis.

Całość powyższych zestawień stara się pokazać, że kartografowie średniowieczni widzieli związek pomiędzy Orkadami a Cykladami. Te pierwsze niemal na wzór Księżyca świecą odbitym blaskiem tych drugim. W ten sposób do

\footnotetext{
${ }^{95}$ Tekst legendy za: Lecoq, La mappemonde d'Henri de Mayence, s. 162 (nr 187). Por. Miller, Mappaemundi. Die ältesten Weltkarten, III. Heft, s. 27.

${ }^{96}$ Tekst legendy za: Westrem, The Hereford Map, s. 195 (nr 462). Por. Bevan - Phillott, Mediaeval Geography, s. 161; Miller, Mappaemundi. Die ältesten Weltkarten, IV. Heft, s. 20; Chekin, Northern Eurasia in Medieval Cartography, s. 164, fragm. 18 (X.12.). Komentarz: Westrem, The Hereford Map, s. 194 (nr 462).

${ }^{97}$ Tekst legendy za: Die Ebstorfer Weltkarte, Bd. I, s. 128 (50 B2/24). Por. Sommerbrodt, Die Ebstorfer Weltkarte, [Teil: Text], s. 56, 6; Miller, Mappaemundi. Die ältesten Weltkarten, V. Heft, s. 27. Komentarz: Die Ebstorfer Weltkarte, Bd. II, s. 282 (50/24).

${ }^{98}$ Tekst legendy za: Miller, Mappaemundi. Die ältesten Weltkarten, III. Heft, s. 75 i 76.
} 
północno-zachodniej krainy mroku trafił jasny promień z południowego-wschodu. Być może jest to graficzna aluzja do monastyzmu i kultury Iroszkotów, starająca się zasugerować przynajmniej niektórym, lepiej wyksztaconym czytenikom map, że to oni właśnie ,schrystianizowali” delijskiego Apollina i otaczające go kręgiem muzy, przenosząc dorobek antyku na kresy Północy, uważane przecież przez długie wieki za symbol skrajnego barbarzyństwa i umysłowej tępoty99. Tymczasem ów marginalizowany alter orbis stał się ważnym ogniwem, żeby nie powiedzieć kamieniem węgielnym kultury europejskiej. Można również widzieć w powyższej paraleli mglistą aluzję do mitu o Hyperborejczykach, których związki z Delos były oczywiste, zaś literacki topos hyperborejski był dobrze znany autorom średniowiecznym ${ }^{100}$. Pojawia się on również explicite na kilku mapach z tego okresu ${ }^{101}$. Można przyjąć, że rzeczona graficzna paralela sugeruje obie przedstawione wyżej możliwości interpretacji, ponieważ do pewnego stopnia są one komplementarne. Byłby to zatem ciekawy przykład połaczenia kulturowej misji Iroszkotów z ,apollinizmem” i toposem hyperborejskim, implikujący milczącą pochwałę Irlandii i Brytanii.

Tab. VI: Schemat Orkad

\begin{tabular}{|c|c|c|c|}
\hline 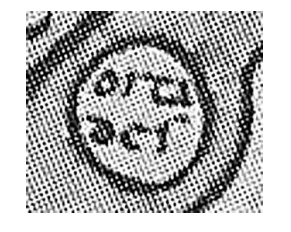 & Hing & & 47 \\
\hline $\begin{array}{l}\text { 1. „Bamberska” mapa } \\
\text { Makrobiusza (X/XI } \\
\text { w.) }\left[\mathrm{A}^{1 / 10}\right]\end{array}$ & $\begin{array}{l}\text { 2. „Oksfordzka” mapa } \\
\text { Makrobiusza I (X/XI } \\
\text { w.) }\left[\mathrm{A}^{1 / 11}\right]\end{array}$ & $\begin{array}{l}\text { 3. „Petersburska” } \\
\text { mapa Makrobiusza } \\
\text { (X/XI w.) }\left[\mathrm{A}^{1} 12\right]\end{array}$ & $\begin{array}{c}\text { 4. Mapa Makrobiusza } \\
\text { z Troyes (X/XI w. ) } \\
{\left[\mathrm{A}^{1 / 13}\right]}\end{array}$ \\
\hline
\end{tabular}

${ }^{99}$ Antyczne i średniowieczne źródła odnoszące się do tej kwestii zostały zebrane w: Kochanek, Die Vorstellung vom Norden und der Eurozentrismus, s. 226-227, przyp. 234 oraz s. 336, przyp. 43; tenże, Etnomedycyna hippokratejska a geopolityczna myśl grecka, s. 36-38, przyp. 34-35.

${ }^{100}$ Por. Kochanek, Die Vorstellung vom Norden und der Eurozentrismus, s. 384-385, przyp. 296-298, gdzie zebrano źródła średniowieczne dotyczące tego właśnie toposu literackiego.

${ }^{101}$ Kraina zamieszkała przez Hyperborejczyków wraz towarzyszącą jej legendą widnieje na mapie z Sawley [A ${ }^{1 / 32}$, na mapie z Hereford [A $\left.1 / 55\right]$ i na tzw. mapie Genueńskiej [A ${ }^{1 / 71}$, por. P. Kochanek, Klauzura pótnocno-wschodniej Azji na mapach średniowiecznych $i$ wczesnonowożytnych, VoxP 36 (2016) t. 65, 234-235 i rys. 29A-B (mapa z Sawley), 266-267 i rys. 38C (mapa z Hereford), 274 i 276, rys. 41E (mapa Genueńska). Należy również dodać, że mapy te oddzielają jednoznacznie krainę hyperborejską od Orkad, a jednocześnie dwie pierwsze mocno akcentują graficznie paralelę między Cykladami i Orkadami, por. tab. V/2 i tab. VI/10 - mapa z Sawley; tab. V/4 i tab. VI/18 - mapa z Hereford. Może to oznaczać, że ich autorzy pragnęli podkreślić symbolikę apollińską, którą można było stosunkowo łatwo utożsamić z wysoką kulturą literacką. Natomiast motyw hyperborejskiej ,świętości” łączonej z samobójstwem u kresu życia potraktowano jako całkowicie sprzeczny z ideałami chrześcijańskimi. 


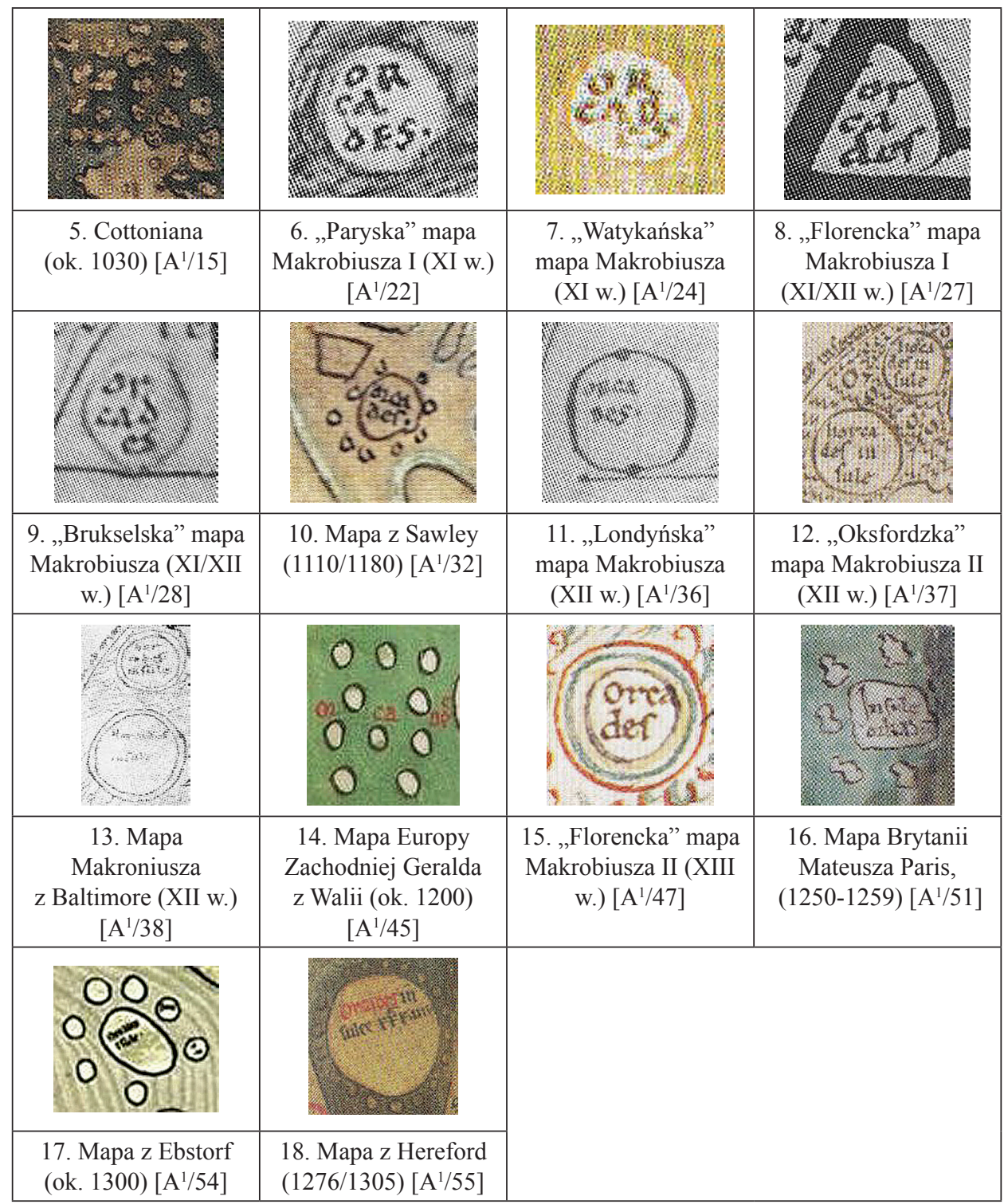

W charakterze uzupełnienia powyższych wywodów źródłowych warto przypomnieć sobie o mapach rekonstrukcyjnych przedstawionych swego czasu przez Konrada Millera (21 XI 1844 - 25 VII 1933). Dorobek tego badacz jest dziś często postponowany i marginalizowany. Tymczasem analiza wielu prac, również tzw. krytycznych edycji źródeł kartograficznych, pokazuje, że współcześni historycy kartografii średniowiecznej czerpią pełnymi garściami właśnie z jego dorobku, zapominając jednak często zacytować w przypisach 
prac tego autora. Tymczasem w kontekście rozważań nad miejscem Cyklad i Orkad na dawnych mapach warto przywołać jego dokonania w zakresie rekonstrukcji map, ponieważ K. Miller oparł się w nich na źródłach oraz na kilkudziesięcioletnich praktycznych doświadczeniach związanych z ich analizą (tab. VII). W swych rekonstrukcjach nawiązał on wyraźnie do schematów zastanych na mapie z Sawley i mapie z Hereford, przenosząc je na obraz świata Pomponiusza Meli (1 poł. I w. po Chr.), Orozjusza ${ }^{102}$, Juliusza Honoriusza ${ }^{103}$, Izydora z Sewilli104 i tzw. „Geografa Raweńskiego"105. Można by zatem powiedzieć, że jest to obraz Cyklad i Orkad u rzeczonych autorów, jaki czytelnik średniowieczny (i wpółczesny) miałby po uprzednim zapoznaniu się z mapami typu „Sawley” lub „Hereford”. W ten sposób siła sugestii obrazu zostałaby skorelowana z mnemotechika. Natomiast jak sami ci autorzy (na)rysowali(by) swoje mapy pozostaje sprawą otwartą.

Tab. VII: Cyklady i Orkady na zrekonstruowanych mapach K. Millera (1898) ${ }^{106}$

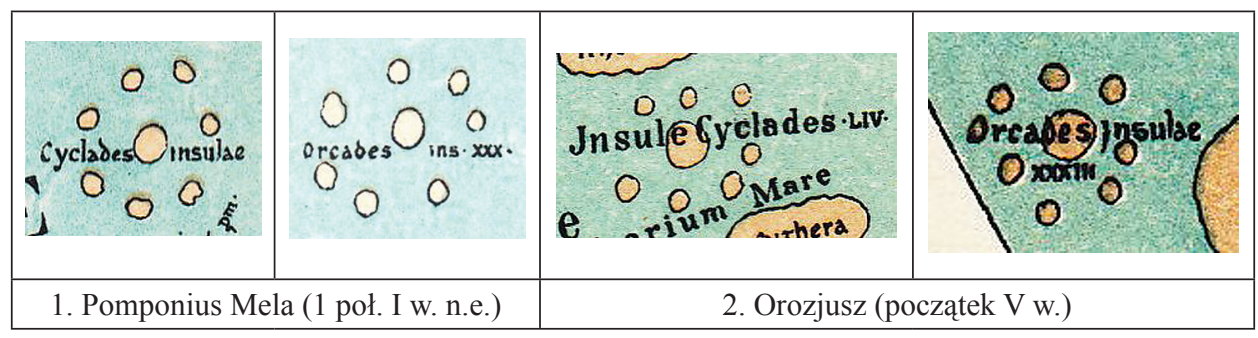

${ }^{102}$ Wydanie krytyczne: Orosius, Historia adversus paganos, CSEL 5, 1-564 (= PL 31, 663B-1174B). Tutaj chodzi o jego opis ekumeny, który znaduje się w: Orosius, Historia adversus paganos I 2, CSEL 5, s. 9, 1 - 40, 9 (= PL 31, 672B-697B = Geographi Latini Minores, s. 56-70).

${ }^{103}$ Wydanie krytyczne: Excerpta eius sphaerae vel continentia (Iulius Honorius), w: Geographi Latini Minores, s. 24-55. Por. Prolegomena, w: Geographi Latini Minores, s. XIX-XXVI. Por. też C. Nicolet - P. Gautier Dalché, Les „quatre sages” de Jules César et la „mesure du monde” selon Julius Honorius: réalité antiique et tradition médiévale, „Journal des Savants” 1986, 157218; M. Spallone, La „Cosmographia” di Iulius Honorius e Cassiodoro, „Segno e Testo” 1 (2003) 129-181; S. Monda, La „Cosmographia” di Giulio Onorio. Un exceptum scolastico tardo-antico, Roma 2008.

${ }^{104}$ Wydanie krytyczne: Isidorus Hispalensis, Etymologiae sive Origines, ed. W.M. Lindsay, Scriptorum Classicorum Bibliotheca Oxoniensis, Oxford 1911 (= PL 82, 73C-728C). Edycja Wallace’a M. Lindsaya (12 II 1858 - 21 II 1937) jest niestety niedostępna dla autora niniejszego artykułu.

${ }^{105}$ Wydanie krytyczne: Ravennas Anonymus, Cosmographia, ed. J. Schnetz, w: Itineraria Romana, vol. 2: Ravennatis Anonymi Cosmographia et Guidonis Geographica, ed. J. Schnetz, indicem composuit et adiecit M. Zumschlinge, Itineraria Romana 2, Stutgardiae 1990. Por. Englisch, Ordo orbis terrae, s. 162-167. Obszerną starszą bibliografię na ten temat zebrał Jerzy Strzelczyk (Gerwazy z Tilbury, s. 84-85, przyp. 35).

${ }^{106}$ K. Miller, Mappaemundi. Die ältesten Weltkarten, VI. Heft: Rekonstruierte Karten, Stuttgart 1898: Orbis Habitabilis ad mentem Pomponii Melae = Tafel 7; P. Orosii Mappamundi $=$ Tafel 3; Isidori Hispalensis Mappamundi = Tafel 2; Sphaera Julii Honorii = Tafel 4; Weltkarte des Ravennaten $=$ Tafel 1 . Tablice te znajdują się $\mathrm{w}$ osobnej zakładce umieszczonej po wewnętrznej stronie tylnej okładki. 

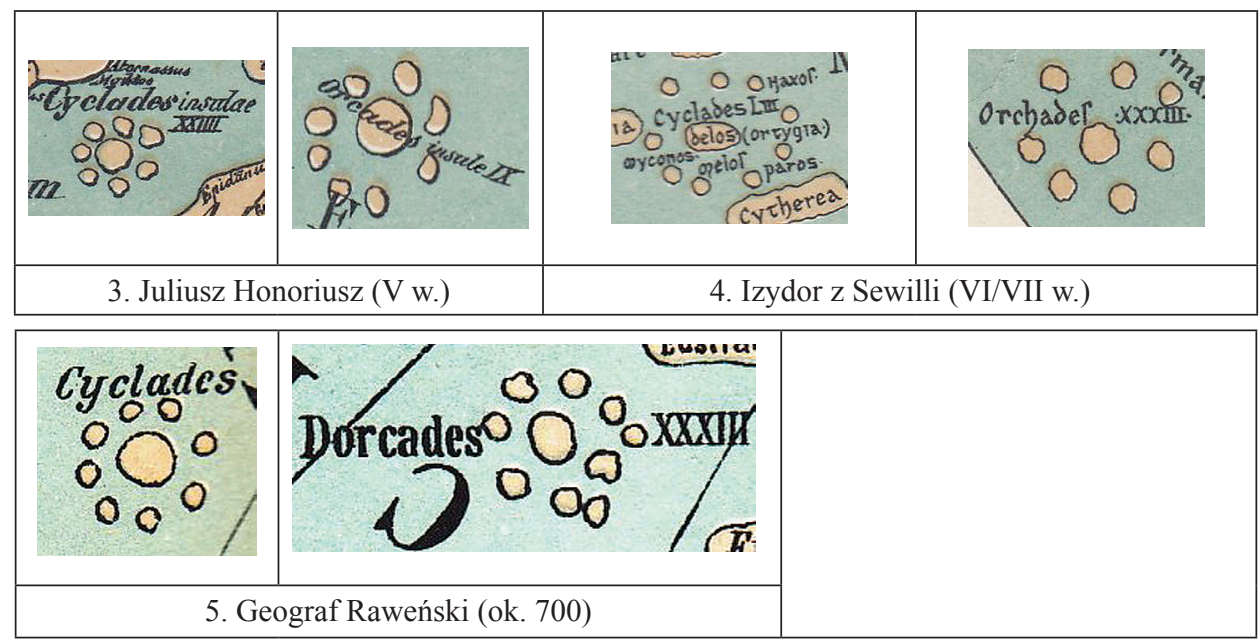

Przedstawione wyżej wyspy nie wyczerpująjednak tego tematu na mapach średniowiecznych. Najbardziej bowiem znaną wyspą zachodnioeuropejskiego kręgu kulturowego była i nadal pozostaje Brytania. W zachowanej spuściźnie grecko-rzymskiej ma ona wiele schematów. W tradycji greckiej uważano ją m.in. za trójkąt ${ }^{107}$. Jednakże w kontekście kartografii średniowiecznej najważniejszy jest kształt wyspy, przechowany w źródłach rzymskich, a ściślej u Tacyta (ok. 55 - ok. 120 po Chr.), który twierdził, że Brytania przypomina swym kształtem podłużną tarczę lub półmisek (oblonga scutula), albo też obosieczną siekierę (bipennis $)^{108}$. Zważywszy zaś, że Tacyt był zięciem Juliusza Agrykoli (40-93), namiestnika Brytanii w latach 77-84, należy uznać, iż przekazał on pewne powszechne wśród Rzymian przekonanie co do schematu tej wyspy. Należy przy tym zwrócić uwagę na fakt, że wszystkie trzy wymienione wyżej przedmioty, mają de facto podłużny (oblongus) kształt, jak to ilustruje aneks nr II. Warto również podkreślić, że w źródłach greckich wyspy dość często są

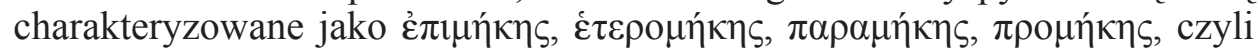
jako skrawki lądu o kształcie wydłużonym, czy też podługowatym ${ }^{109}$. Z kolei te terminy geograficzne są bardzo blikie pojęciom geometrycznym, takim

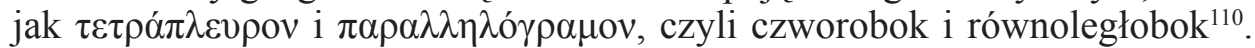
Takie zaś określanie wysp w literaturze fachowej koresponduje dobrze z ich obrazem na mapach średniowiecznych, gdzie przybierają one kształt podłużny

${ }^{107}$ Por. Kochanek, Iluzja schematów choro- i topograficznych, s. 75, 83 i 97.

${ }_{108}$ Tacitus, Agricola 10, 3, ed. E. Koestermann: Tacitus, Libri qui supersunt, t. 2, fasc. 2: Germania. Agricola. Dialogus de oratoribus, Lipsiae 1964, 39, 26-28: „Formam totius Britanniae Livius veterum, Fabius Rusticus recentium eloquentissimi auctores oblongae scutulae vel bipenni adsimulavere". Por. G. Ferrara, La forma della Britannia secondo la testimonianza di Tacito: nota, Milano 1904; tenże, Della voce „Scutula”. Nota di semantica latina, Milano 1905.

${ }^{109}$ Por. Kochanek, Iluzja schematów choro- i topograficznych, s. 106-107.

${ }^{110}$ Por. tamże, s. 107. 
lub kształt prostokąta w różnych jego wariantach. Ponieważ zaś prawie każda mapa dostarcza tego typu przykładów, nie ma zatem potrzeby ilustrowania tego schematu. Nie trzeba też dodawać, że ten prosty schemat był łatwy do zapamiętania, co niewattpliwie podnosiło jego wartość dydaktyczną zwiększając tym samym częstotliwość jego użycia.

Do trójkąta porównywano także Italię. Istnienie takiego schematu Półwyspu Apenińskiego jest uchwytne już u Polibiusza (ok. 200 - ok. 118 p.n.e.) ${ }^{111}$. Strabon, który raczej nie podzielał opinii swego rodaka, był jednak zdania, że Italia bardziej przypomina $\tau \varepsilon \tau \rho \alpha ́ \pi \lambda \varepsilon v \rho o v$ niż trójkąt ${ }^{112}$. W kontekście powyższych figur geometrycznych należy zwrócić uwagę na tezę Pliniusza, dla którego Italia ,est [...] folio maxime querno adsimilata, multo proceritate amplior quam latitudine [... "'113. Pogląd ten przytoczył również Solinus ${ }^{114}$ i Rutilius Namatianus (1 poł. V w. $)^{115}$. Powyższa opinia Pliniusza zdaje się sugerować, że jego liść dębu przypomina w pewnym stopniu Polibiuszowy trójkąt. Jednak o ile Polibiusz do schematyzacji Italii zaaplikował terminologię geometryczną, o tyle Pliniusz określił kształt jej terytorium za pomocą nomenklatury wziętej niejako z życia, stosując w tym sensie schemat geograficzny. Reminiscencje tej schematyzacji można prawdopodobnie dostrzec na kilku mapach średniowiecznych, co ilustruje tablica nr VIII.

Tab. VIII: Trójkąt - schemat Italii

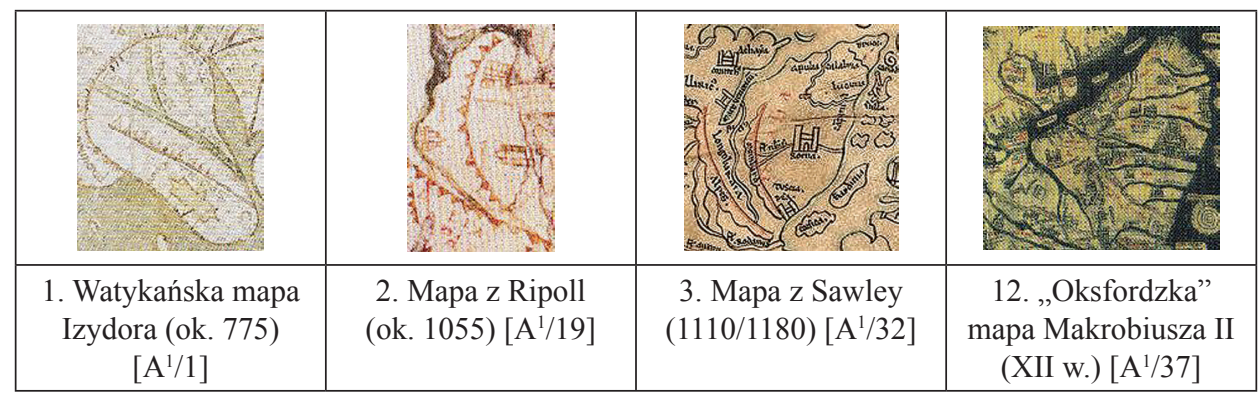

Z kolei tablica IX prezentuje kształt Italii, będące być może dalekim echem opinii Strabona, czyli tezy, która za jej schemat uznawała czworobok. W tym

${ }^{111}$ Polybius, Historiae II 14, 4, ed. Büttner-Wobst, vol. 1, s. 139, 12-13. Por. Strabo, Geographica V 1, 2, C. 210, ed. Meineke, vol. 1, s. 287, 22. Por. też J.-M. Bertrand, Sur quelques descriptions antiques de la péninsule italienne, „Mappemonde” 2 (1986) 26-30; tenże, De l'emploi des métaphores descriptives par les géographes de l'Antiquité, „Dialogues d'Histoire Ancienne” 15 (1989) 64; Kochanek, Iluzja schematów choro- i topograficznych, s. 86, przyp. 51.

${ }^{112}$ Strabo, Geographica V 1, 2, C. 210, ed. Meineke, vol. 1, s. 288, 15.

${ }^{113}$ Plinius, Naturalis historia III 43, ed. Mayhoff, vol. 1, s. 249, 4-5.

${ }^{114}$ Solinus, Collectanea rerum memorabilium 2, 20, rec. T. Mommsen, s. 39, 13: „(Italia) similis querneo folio, scilicet proceritate amplior quam latitudine".

${ }^{115}$ Rutilius Namatianus, De reditu suo II 19, ed. P. van de Woestijne: Rutilius Namatianus, De reditu suo, Antwerpen - Paris 1936, 63: ,[...] quernae similem [...] frondi [...]”. 
przypadku brak jednak zachowanych w źródłach ogniw pośrednich, które łączyłyby Strabona z kartografią średniowieczną. Jednak mimo to, jak wynika $\mathrm{z}$ poniższych schematów, istniało $\mathrm{w}$ pewnych kręgach kartografów średniowiecznych przekonanie, że kształt Półwyspu Apenińskiego jest zbliżony do czworoboku, a ściślej do prostokąta.

Tab. IX: Czworobok - schemat Italii

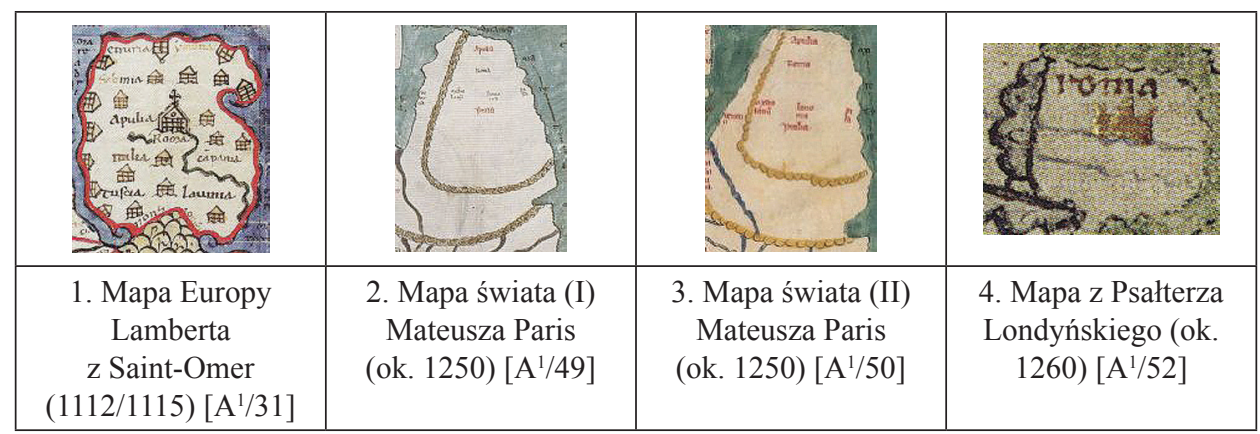

W ścisłym związku ze schematyzacją Italii pozostaje kwestia tzw. buta włoskiego. Tego kształtu Półwyspu Apenińskiego nie ma w źródłach antycznych. Jest tam natomiast porównanie południowej części półwyspu do rogów, które tworzy Półwysep Saletyński i Półwysep Kalabryjski. Wspomina o nich Pomponiusz Mela ${ }^{116}$, Pliniusz ${ }^{117}$ i Solinus ${ }^{118}$. Geneza tego schematu sięga jednak czasów o wiele dawniejszych niż początki cesarstwa. Ich echem jest zachowany u Dionizjusza z Halikarnasu (ok. 60 p.n.e. - ok. 7 n.e.) fragment dzieła Hellanikosa z Lesbos (ok. 480 - ok. 400 p.n.e.) ${ }^{119}$. Hellanikos opowiada w nim o Heraklesie, który pędził woły Geriona do Argos. W czasie tej drogi, już na terenie półwyspu zwanego dziś apenińskim od stada miało się odłączyć cielę. Herakles udał się na jego poszukiwanie. Przeszedł wówczas półwysep i dotarł na Sycylię, gdzie rozpytywał mieszkańców o „zbiega”, używając lokalnego terminu na określenie cielęcia - ouitoulos. Konsekwencją tego wydarzenia było to, że mieszkańcy Sycylii zaczęli nazywać półwysek, a przynajmniej jego

116 Pomponius Mela, Chorographia II 58, rec. C. Frick: Pomponius Mela, Chorographia, Stutgardiae 1968, 41, 20-22: „(Italia) in duo cornua finditur, respicitque altero Siculum pelagus, altero Ionium”; tamże, II 67, rec. Frick, s. 43, 11-12: „Frons eius in duo quidem se cornua, sicut supra diximus, scindit".

${ }^{117}$ Plinius, Naturalis historia III 43, ed. Mayhoff, vol. 1, s. 249, 5-8: ,[...], in laevam se flectens cacumine et Amazonicae figura desinens parmae, ubi a medio excursu Cocynthos vocatur, per sinus lunatos duo cornua emittens, Leucopatram dextra, Lacinium sinistra".

${ }^{118}$ Solinus, Collectanea rerum memorabilium 2, 21, rec. Mommsen, s. 39, 14-16: „Ubi longius abiit, in cornua duo scinditur, quorum alterum Ionium respectat aequor, alterum Siculum”.

${ }^{119}$ Hellanicus Lesbius I A/4, F 111, 2-3, hrsg. von F. Jacoby, w: Die Fragmente der griechischen Historiker, Teil I: Genealogie und Mythographie, A: Vorrede. Text. Addenda. Konkordanz, Leiden 1957, 134, 28 - 135, 6 (= Dionysus Halicarnasensis, Antiquitates romanae, I 35, 2-3, ed. C. Jacoby: Dionysus Halicarnasensis, Antiquitates romanae, vol. 1, Lipsiae 1885, 55, 14 - 56, 9). 
południową część, Ouitoulia. ${ }^{120} \mathrm{~W}$ ten sposób pojawia się w etymologii Italii delikatnie, rzec by można, naszkicowany motyw rogów. Subtelności te pominął Timajos z Tauromenion (ok. 350 - ok. 260 p.n.e.), a przynajmniej Warron (116-27 p.n.e.), który powołując się na tego sycylijskiego historyka stwierdził: „Graecia enim antiqua, ut scribit Timaeus, tauros vocabat italos”121. W grę jednak wchodzą tutaj już nie cielęta, lecz byki. Schemat rogatego południa Włoch nabiera w ten sposób znaczenia symbolicznego, ukazując dziką i nieokiełznaną potęge imperium, które jako wcielenia byka panuje nad Śródziemnomorzem, leżąc w jego geograficznym centrum. Ten tak sugestywny schemat nie zrobił jednak prawie żadnej kariery w kartografii średniowiecznej. Można co prawda starać się go dostrzec na mapie Paulina Minoryty (tab. X, rys.1-2 $=\mathrm{A}^{1 / 58}$ 59), ale interpretacja kształtu południowej Italii nie jest tutaj jednoznaczna, ponieważ mapy te opierają się na ówczesnych portolanach. W konsekwencji mapy Paulina są więc mapami, które starają się po prostu oddać rzeczywisty obraz linii brzegowej Italii, idąc za współczesnymi sobie mapami żeglarskimi. Inaczej przedstawia się sprawa na słynnych szkicach Opicinusa de Canistris (1296-1350). Wśród wielu podobnych rysunków tego autora przedstawiających tzw. but włoski, najbardziej znany jest ten, który przedstawia Europę jako Nierządnicę (Watykan, Biblioteca Apostolica Vaticana, Ms Vat. Lat. 6435, fol. $\left.77^{\mathrm{r}}\right)^{122}$. Jednak i tutaj schemat buta rozpoczyna się grosso modo na południe od Neapolu (tab. X, rys. $3=\mathrm{A}^{1 / 62}$ ). Dopiero kopia traktatu Riccobalda z Ferrary (ok. 1246 - ok. 1318), pochodząca z 1 poł. XV w., zawiera rysunek przedstawiający Italię jako „Stivale” (tab. X, rys. 4 = A $1 / 67$ ). Czy schemat ten znajdował się już w oryginale jego kroniki, pozostaje kwestią otwartą ${ }^{123}$. Generalnie można by uznać, że antyczny schemat rogów (byka) wieńczących południowe kresy Półwyspu Apenińskiego był tak sugestywny i mocno zakorzeniony, że na wiele wieków skutecznie blokował każdą inną formę schematyzacji Italii.

${ }^{120}$ Por. G. De Sensis Sestito, Italo, Italía, Italioti: alle origini di una nozione, w: Unità multiple. Centocinquant'anni? Unità? Italia?, a cura di G. De Sensis Sestito e M. Petrusewicz, Saggi 347 , Soveria Mannelli 2014, 62-65. Por. F. Prontera, Imagines Italiae. Sulle più antiche visualizzazioni e rappresentazioni geografiche dell'Italia, „Athenaeum” 64 (1986) 295-320.

${ }^{121}$ Timaeus Tauromenitanus, III B/566, F 42b, ed. F. Jacoby, w: Die Fragmente der griechischen Historiker, Teil III: Geschichte von Staedten und Voelkern (Horographie und Ethnographie), B: Autoren ueber einzelne Staedte (Laender), Leiden 1964, 614, 8-12 (= Varro, Res rusticae, II 5, 3, ed. G. Goetz: Varro, Res rusticae, Lipsiae 1912, 91, 12-15). Por. Timaeus Tauromenitanus, III B/566, F 42a, ed. F. Jacoby, s. 614, 3-8 (= Aulus Gellius, Noctes Atticae XI 1, 1, ed. C. Hosius: Aulus Gellius, Noctes Atticae, vol. 2, Lipsiae 1903, 1, 6-13).

${ }^{122}$ Dzieło Opicinusa de Canistris zachowało się w dwóch kodeksach, które znajdują się w Bibliotece Watykańskiej: 1) Cod. Pal. Lat. 1993 - wydany przez Richarda Salomona (22 IV 1884 - 3 II 1966), por. R. Salomon, Opicinus de Canistris. Weltbild und Bekenntnisse eines avignonesischen Klerikers des 14. Jahrhunderts, 1. Bd.: Textband, 2. Bd.: Tafelband, Studies of the Warburg Institute I A-B, London 1936; 2) Cod. Vat. Lat. 6435 - wydany przez Muriel Laharie (1947 - 2 IV 2015), por. M. Laharie, Le journal singulier d'Opicinus de Canistris (1337 - vers 1341): Vaticanus Latinus 6435, t. 1-2, ST 447-448, Città del Vaticano 2008.

${ }^{123}$ Por. Kochanek, Iluzja schematów choro- i topograficznych, s. 87. 
Podkreślał on bowiem nie tylko siłę narodu rzymskiego, lecz także siłę ludów, które przejęły jego italskie dziedzictwo, co stanowiło słuszny powód do dumy. Tymczasem schemat buta, szczególnie w kontekście graficznym przekazanym przez Opicinusa de Canistris, był ewidentną obelgą dla „Italików”, których ziemię ojczystą zdegradowano do roli prawego obuwia nierządnicy, co implikowało również jak najgorszą opinię o nich samych.

Tab. X: „Rogi” i „Stivale” - schematy Italii

\begin{tabular}{|c|c|c|c|}
\hline 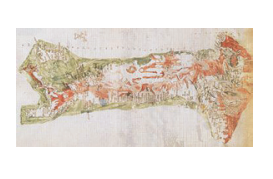 & se & & 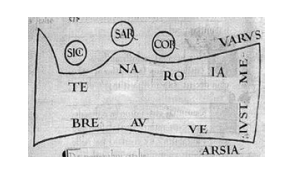 \\
\hline $\begin{array}{l}\text { 1. Paulinus Minorita: } \\
\text { Mapa (I) Italii } \\
\text { (ok. 1320) }\left[\mathrm{A}^{1 / 58}\right]\end{array}$ & $\begin{array}{l}\text { 2. Paulinus Minorita: } \\
\text { Mapa (II) Italii } \\
\text { (ok. 1320) }\left[\mathrm{A}^{1 / 59}\right]\end{array}$ & $\begin{array}{c}\text { 3. Opicinus de Canis- } \\
\text { tris: „Europa - Nierzą- } \\
\text { dnica” }(1337-1341) \\
{\left[\mathrm{A}^{1} / 62\right]}\end{array}$ & $\begin{array}{c}\text { 4. Mapa Italii } \\
\text { z Aix-en-Provence } \\
\left(1 \text { poł. XV w.) }\left[\mathrm{A}^{1 / 67}\right]\right.\end{array}$ \\
\hline
\end{tabular}

Natomiast jednym z klasycznych, geometrycznych schematów Hiszpanii, czy też szerzej Półwyspu Iberyjskiego, jest kształt trójkąta. Wspomina o nim Orozjusz ${ }^{124}$, zaś w dobie rozkwitu zachodniego średniowiecza przywołuje go Hugo od św. Wiktora (1096-1141) $)^{125}$, Gerwazy z Tilbury ${ }^{126}$ oraz inne przekazy łacińskie ${ }^{127}$. Schemat ten pojawia się również na bardzo wielu mapach średniowiecznych (tab. XI). Najwcześniejsze z nich znajdują się bądź w rękopisach zawierających odpisy dzieł autorów pochodzących z Hiszpanii, bądź w manuskryptach, które powstały na terenie Półwyspu Iberyjskiego (tab. XI, rys. 1, 3-4 i 8), głównie zaś na tzw. mapach Beatusa z Liébana (tab. XI, rys. 2, 5-6, 9-11, 14-15 i 20). Na Watykańskiej mapa Izydora (tab. XI, rys. $\left.1=\mathrm{A}^{1 / 1}\right)$ Hiszpania ma kształt trójkąta, który został przez jej rysownika podzielony na dwa mniejsze. W pole lewego wpisano nazwę „Ispania ulterior”, natomiast prawy to „Ispania inferior”"28. Na innych mapach trójkąt jest mniej lub bardziej regularny. Duża liczba map przedstawiających Hiszpanię w formie tej figury geo-

${ }^{124}$ Orosius, Historia adversus paganos I 2, 69, CSEL 5, s. 26, 10 (= PL 31, 688B = Geographi Latini Minores, s. 64, 21).

${ }^{125}$ Hugo de Sancto Victore, Descriptio mappae mundi XXIII 622, éd. par P. Gautier Dalché: La „Descriptio mappe mundi” de Hugues de Saint-Victor. Texte inédit avec introduction et commentaire, Collection des Études Augustiniennes. Série Moyen Âge et Temps Modernes [20], Paris 1988, 156.

${ }^{126}$ Gervasius Tilleberiensis, Otia imperialia II 10, ed. Banks - Binns, s. 302.

${ }^{127}$ Wykaz tych źródeł znajduje się w: Kochanek, Iluzja schematów choro- $i$ topograficznych, s. 88 , przyp. 61 .

${ }^{128}$ Tekst legend za: Uhden, Die Weltkarte des Isidorus von Sevilla, s. 26 i 28. Por. F. Glorie, Mappa mundi (e codice Vatic. Lat. 6018), w: Itineraria et alia geographica, CCL 175, Turnholti 1965 , s. 461 i 465. 
metrycznej świadczy z jednej strony o popularności tego schematu, z drugiej zaś o znaczącej roli Orozjusza i Beatusa, benedyktyńskiego mnicha z Liébana, w jego rozpowszechnieniu na łacińskim Zachodzie. Jeśli chodzi o częstotliwość występowania, to „trójkąt hiszpański” ustępuje w kartografii omawianego tutaj okresu tylko „trójkątowi sycylijskiemu”. Warto również podkreślić widoczną dominację geometrycznego schematu trójkąta w kartografii średniowiecznej jako takiej. Odnosi się on bowiem, jak wskazano wyżej, do Sycylii, Italii i Hiszpanii, a zatem do bardzo ważnych elementów średniowiecznej mapy.

Tab. XI: Trójkąt - schemat Hiszpanii

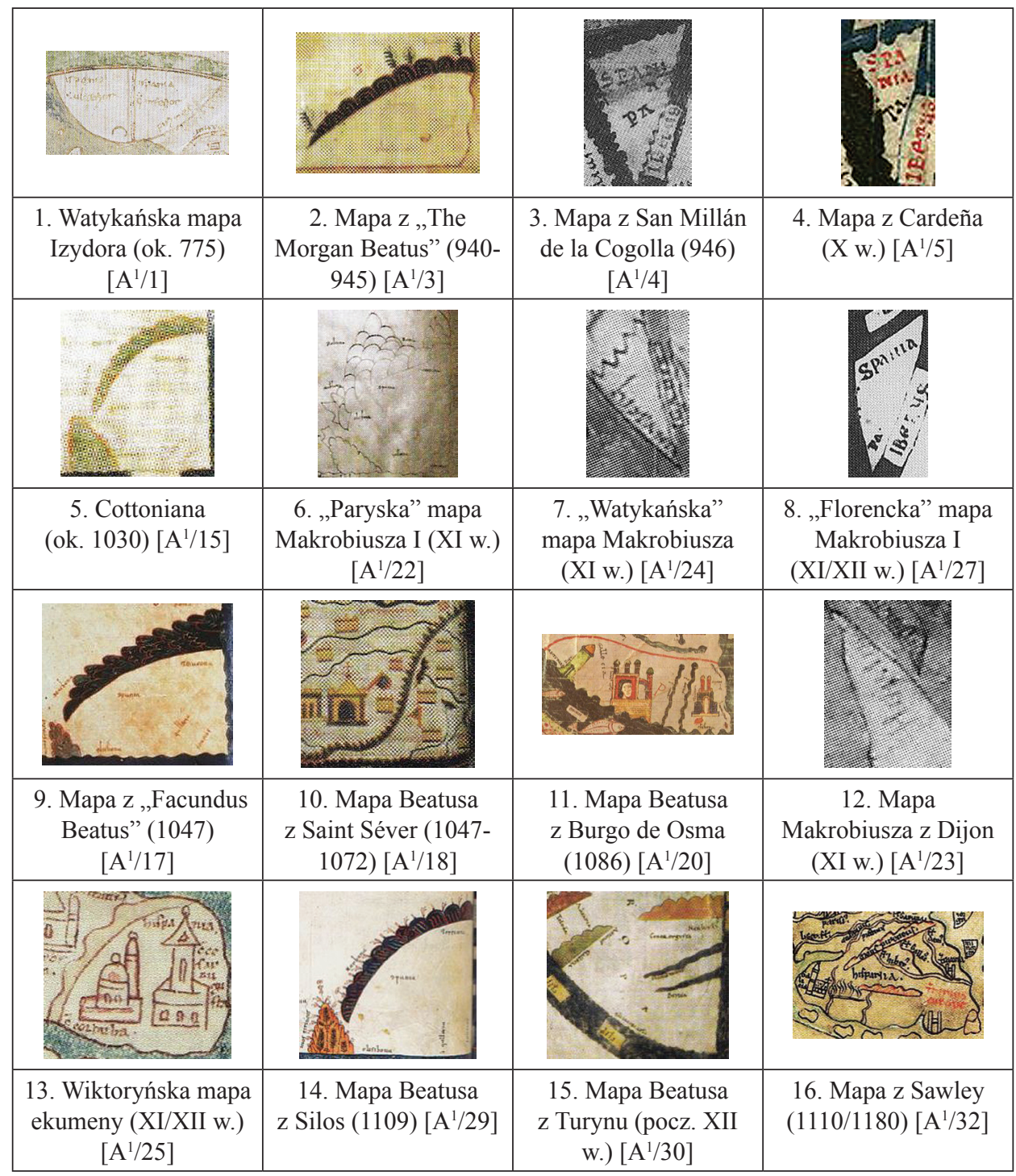




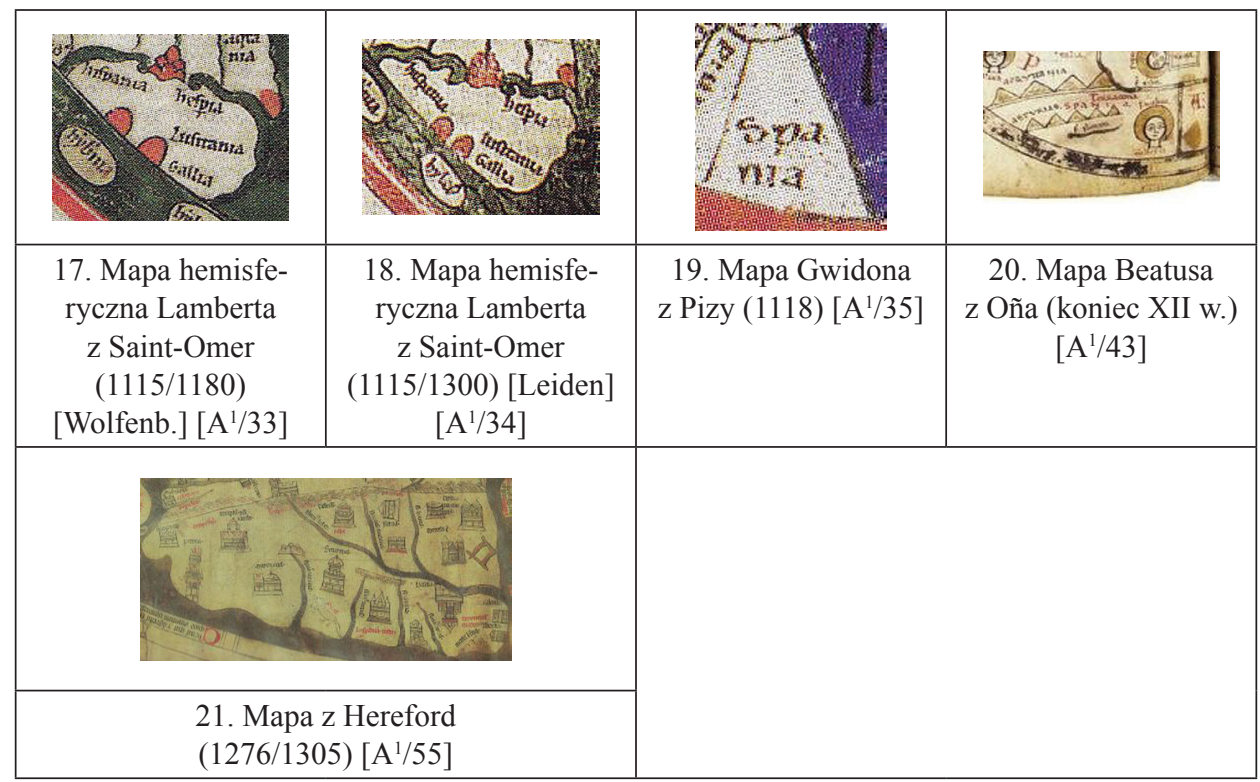

Dobrze widoczny na analizowanych mapach jest także schemat Alp ${ }^{129}$. Strabon twierdził, że podgórze alpejskie jest koliste i przypomina morską zatokę ${ }^{130}$. Pliniusz z kolei podkreślał ich księżycowatą formę - lunata iuga ${ }^{131}$, co powtarza Dicuil (ok. 755 - ok. 825) ${ }^{132}$. Natomiast Solinus ogranicza niejako to porównanie, używając pojęcia iuga Alpium ${ }^{133}$. Z kolei u Orozjusza ${ }^{134}$, w anonimowym traktacie „Cosmographia” 135 oraz u Gerwazego z Tilbury ${ }^{136}$ widnieje porównanie Alp do zapór, grobli lub wałów - obices, a stąd już tylko krok do określenia tych gór mianem murów obronnych. Tak też postąpił, inspirowany zapewne przez swego rodaka Orozjusza, Izydor z Sewilli, pisząc: „Hae (Alpes) sunt enim

${ }^{129} \mathrm{Na}$ temat graficznego przedstawiania gór na mapach średniowiecznych por. J. Röger, Die Bergzeichnung auf den älteren Karten. Ihr Verhältnis zur darstellenden Kunst, München 1910. Por. też C. Delano-Smith, Signs on Printed Topographical Maps, ca. 1470 - ca. 1640, w: The History of Cartography, vol. 3, part 1: Cartography in the European Renaissance, ed. D. Woodward, Chicago 2007, 528-590.

${ }^{130}$ Strabo, Geographica V 1, 3, C. 210, ed. Meineke, vol. 1, s. 288, 20-21.

${ }^{131}$ Plinius, Naturalis historia III 38, ed. Mayhoff, vol. 1, s. 247, 14.

${ }^{132}$ Dicuilus, Liber de mensura orbis terrae 1, 9, ed. G. Parthey: Dicuilus, Liber de mensura orbis terrae, Berlin 1870 [reprint: Graz 1969], 8, 13.

${ }^{133}$ Solinus, Collectanea rerum memorabilium 2, 19, rec. Mommsen, s. 39, 8; tamże, 2, 25, ed. Mommsen, s. 41, 4. Por. Anonymus Leidensis, De situ orbis I 4, 14, ed. R. Quadri: Anonymus Leidensis, De situ orbis, Thesaurus Mundi 13, Padua 1974, 10, 27; tamże II 3, 11, ed. Quadri, s. 53, 10.

${ }^{134}$ Orosius, Historia adversus paganos I 2, 61, CSEL 5, s. 24, $12-25,1(=\mathrm{PL} 31,687 \mathrm{~B}=\mathrm{Ge}-$ ographi Latini Minores, s. 63, 23).

${ }^{135}$ Cosmographia II 28, w: Geographi Latini Minores, s. 97, 3: „[...] ubi Alpium obicibus cingitur (Italia) [...]".

${ }^{136}$ Gervasius Tilleberiensis, Otia imperialia II 8, ed. Banks - Binns, s. 254. 
quae Italiae murorum exhibent vicem"137. Tę samą logikę, która każe widzieć

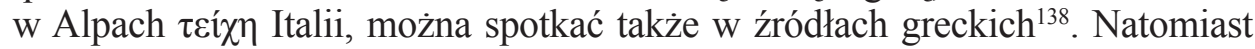
Rutilius Namatianus, używając w tym kontekście terminu claustra, czyli „zapora” lub „tama”, pisze, że Rzymu strzegą podwójne claustra - Alpy i Apeniny ${ }^{139}$. Podobnie postrzegał tę rzecz Gwido z Pizy (XII w.), pisząc o claustra Alpium ${ }^{140}$. W kontekście powyższej wizji Alp warto zwrócić uwagę na fakt, że porównanie gór do murów obronnych lub zapór trzeba uznać za swego rodzaju skojarzenie „,naturalne”, tzn. takie, które przychodzi na myśl każdemu człowiekowi, który patrzy na potężną barierę górską. W tym sensie opinie autorów cytowanych wyżej źródeł należy traktować nie tyle jako wyszukane idee w zakresie schematyzacji, lecz jako efekt naturalnych, zdroworozsądkowych skojarzeń, właściwych ludziom jako takich, bez względu na czas i miejsce.

Można zatem przyjąć, że kartografowie średniowieczni mogli z jednej strony iść za owymi literackimi autorytetami, z drugiej zaś kierować się doświadczeniem i zwykłym, naturalnym skojarzeniem, traktując góry jako wręcz opatrznościową barierę obronną ${ }^{141}$. Idea ta jest szczególnie dobrze widoczna w przypadku Alp rozumianych jako swego rodzaju mury obronne Italii (tab. XII). W ten sposób podkreślono organiczny związek pomiędzy naturalnymi, czyli stworzonymi przez Boga granicami a walorami obronnymi danego terytorium, rozumianymi jako konsekwencja Jego woli. Jak widać na poniższych wycinkach map, kartografowie średniowieczni, idąc grosso modo za tradycją, której echem są wersy Rutiliusa Namatianusa, brali pod uwagę nie tylko Alpy, lecz także Apeniny (tab. XII, rys. 2, 4-5 i 7), tworzące de facto swoisty podwójny mur obronny, za rozbudowany system naturalnych fortyfikacji, którego zadaniem było zabezpieczenie nie tyle Italii jako takiej, co Rzymu przed atakiem od strony lądu. Warto zauważyć, że wierzchołki gór, imitujące blanki murów, są zawsze zwrócone do zewnętrz, podkreślając ich defensywny charakter w stosunku do obszaru po drugiej stronie. Należy również zauważyć, że schemat ten utrzymał się w kartografii średniowiecznej przez całe średniowiecze (tab. XII, rys. 1 i 8). Nie była to zatem idea efemeryczna, lecz niemalże swego rodzaju geo-kartograficzny dogmat epoki. Owe linie obronne można również traktować, jak już wspomniano wyżej, jako opatrznościowe, czyli

${ }^{137}$ Isidorus Hispalensis, Etymologiae XIV 8, 19, PL 82, 523A.

${ }^{138}$ Chrestomathia Straboniana VI 43, w: Geographi Graeci Minores II, s. 566. Jeśli chodzi o schematyzację Alp oraz innych pasm górskich, por. Kochanek, Iluzja schematów choro- $i$ topograficznych, s. 104.

${ }^{139}$ Rutilius Namatianus, De reditu suo II 33-36, ed. Woestijne, s. 64. Por. K. Winckler, Die Alpen im Frühmittelalter. Die Geschichte eines Raumes in den Jahren 500 bis 800, Wien 2012, 66-68.

${ }^{140}$ Guido, Geographica 11, ed. J. Schnetz: Itineraria romana, vol. 2: Ravennatis Anonymi Cosmographia et Guidonis Geographica, Stuttgardiae 1990, 115, 53.

${ }^{141}$ Por. Kochanek, Klauzura pótnocno-wschodniej Azji, s. 211-344. Por. też W. Iwańczak, Borders and Borderlines in Medieval Cartography, w: Frontiers in the Middle Ages. Proceedings of the Third European Congress of Medieval Studies, Jyväskylä, 10-14 June 2003, ed. by O. Merisolo - P. Pahta, Textes et Études du Moyen Âges 35, Louvain-la-Neuve 2006, 661-672. 
jako naturalny system defensywny dany Rzymowi z woli Bożej Opatrzności, a zatem eksponowana rola tego miasta były już niejako zapisana w planie Boga w momencie stwarzania świata. W ten sposób starano się być może podkreślić ideę prymatu Rzymu wśród metropolii Pentarchii ${ }^{142}$.

Tab. XII: Schemat(y) Alp

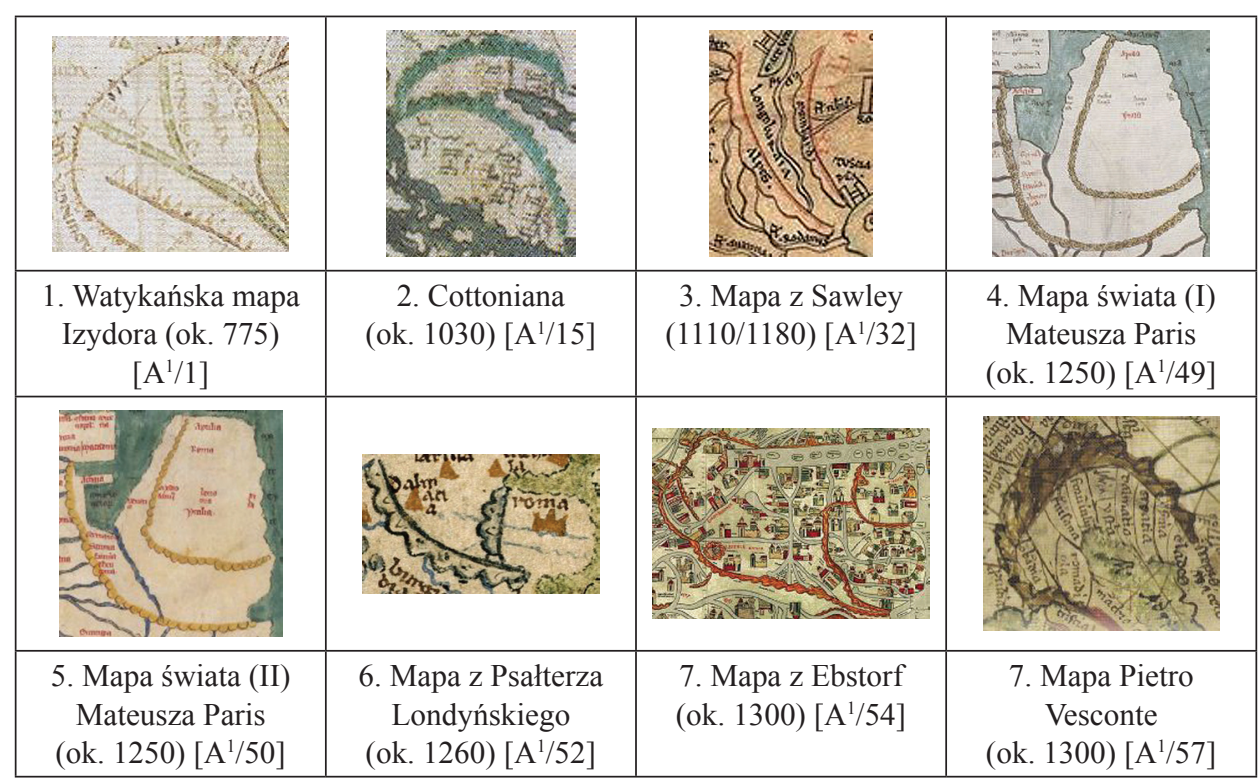

Dla lepszego zilustrowania tego zagadnienia warto przyjrzeć się bliżej trzem potężnym systemom obronnym opartym na powyższej logice, które znajdują się na mapie $\mathrm{z}$ Ebstorf (rys. $13 \mathrm{~A}-\mathrm{C}=\mathrm{A}^{1 / 54}$ ). Pierwszy z nich (rys. $13 \mathrm{~A}=$ tab. XII, rys. 7) to właśnie obraz przedstawionych wyżej naturalnych fortyfikacji Półwyspu Apenińskiego. Drugi system obronny (rys. 13B) dotyczy Półwyspu Iberyjskiego, czyli Hiszpanii. Trzeci zaś to klauzura północno-wschodniej Azji, czyli obszar zamieszkały przez tzw. ludy zamknięte (inclusae nationes), które to zagadnienie było już szczegółowo analizowane przez niżej podpisanego ${ }^{143}$. Biorąc pod uwagę zorientowanie wierzchołków gór, można tutaj określić funkcję owych systemów naturalnych barier. Jak już wskazano wcześniej w przypadku Italii wierzchołki te są zorientowane ad extra, podkreślając tym samym, że stanowią one wały obronne Półwyspu Apenińskiego i Rzymu. W przypadku Hiszpanii, gdzie niektóre pasma górskie znajdują się we wnętrzu owego naturalnego pierścienia obronnego, można wnioskować, że Półwysep Iberyjski, zdaniem rysowników mapy z Ebstorf, posiada także silne wewnętrzne podziały na wrogie względem siebie terytoria. W ten sposób twórcy rzeczonej mapy mogli starać

${ }_{142}$ Por. tenże, Winiety metropolii Pentarchii na mapach średniowiecznych $i$ wczesnonowożytnych, VoxP 34 (2014) t. 62, 213-296.

${ }^{143}$ Por. przyp. 141. 
się zasygnalizowali chociażby arabską okupację półwyspu. Wreszcie klauzura północno-wschodniej Azji jest otoczona barierą górską której wierzchołki są skierowane ad intra, co oznacza, że ów system obronny ma za zadanie blokować ludy zamknięte w jego obrębie i chronić te, które znajdują się poza nim. W ten sposób z kolei mapa z Ebstorf sygnalizuje jasno zagrożenie jakie niosą dla reszty ekumeny tzw. ludy zamknięte. Te trzy systemy sugerują współczesnemu analitykowi mapy geopolityczne i militarne widzenie obszarów euro-azjatyckich przez średniowiecznych kartografów. Można by wręcz powiedzieć, że systemy obronne ówczesnej Europy uważali oni za słabe, ponieważ inclusae nationes po przejściu blokującej je bariery górskiej nie natrafiały na podobne przeszkody naturalne wcześniej niż na wysokości Italii i Hiszpanii. Europa stała zatem otworem przed ówczesnym azjatyckim barbarzyństwem, broniona tylko przez fortyfikacje wzniesione ręką ludzką. Ręka Boska tymczasem zatroszczyła się o regiony Europy, będące źródłem i depozytariuszem wiary, czyli o italski Rzym i hiszpańską Kompostellę. Logika kartograficzna koresponduje tutaj również z ideą największych europejskim miejsc pielgrzymkowych. Jest to w rzeczywistości ta sama logika, którą zawierają tzw. mapy Beatusa. Nie jest to przypadek, ponieważ wszystkie te mappaemundi powstały w benedyktyńskim środowisku zakonnym.

\begin{tabular}{|c|c|c|}
\hline Rys. 13A & Rys. 13B & Rys. 13C \\
\hline 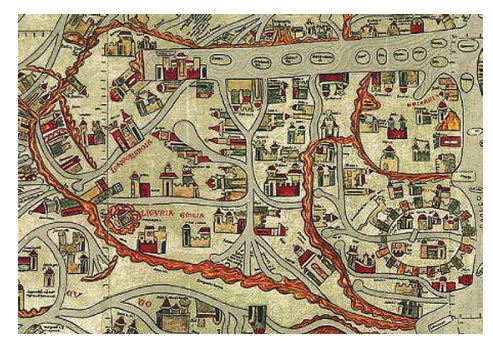 & 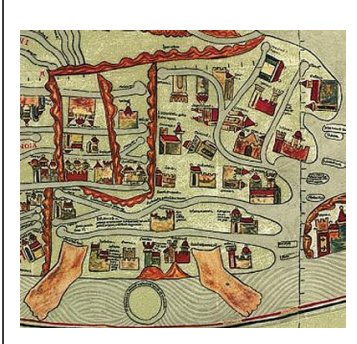 & 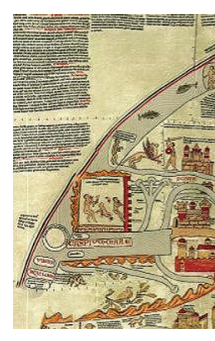 \\
\hline
\end{tabular}

Rys. 13A-C: Idea trzech naturalnych twierdz, zbudowanych na bazie gór

Z kolei wspomniany wyżej schemat Propontydy w kształcie litery $\Phi^{144}$ wchodzi w skład swego rodzaju rodziny schematów, które można określić mianem „literowych"145. Do niej należy również ujście Nilu, którego kształt już Grecy epoki klasycznej charakteryzowali za pomocą czwartej litery swego alfabetu, czyli widzieli w nim trójkątny schemat delty $(\Delta)^{146}$. Z punktu widzenia niniejszych analiz ważne jest podkreślenie, że w źródłach łacińskich schemat

${ }^{144}$ Por. przyp. 52.

${ }^{145}$ Por. Kochanek, Iluzja schematów choro- i topograficznych, s. 96-97.

146 Wykaz źródeł greckich i łacińskich w tej materii, poczynają od Ajschylosa (525/524-456 p.n.e.), znajduje się w: Kochanek, Iluzja schematów choro- i topograficznych, s. 84-85 i przyp. 43-46. 
ten pojawia się m.in. u Pliniusza ${ }^{147}$, Ammiana Marcellina ${ }^{148}$, Solinusa ${ }^{149}$, Marcjanusa Kapelli ${ }^{150}$, Dicuila ${ }^{151}$, Anonima z Leidy ${ }^{152}$, Honoriusza z Autun ${ }^{153}$ i Gerwazego z Tilbury ${ }^{154}$. W zachowanej spuściźnie kartograficznej średniowiecza spotyka się go relatywnie często (tab. XIII, rys. 1-17). Pierwsze ślady użycia tego schematu są uchwytne na mapach Beatusa z Liébana (tab. XIII, rys. 1, 3, 5, 9-10 i 13). Również wybrane przykłady map z okresu wczesnonowożytnego przywołują ten właśnie kształt ujścia Nilu (tab. XIII, rys. 18-28). Należy także podkreślić, że starożytni starali się w miarę precyzyjnie określić liczbę ramion, którymi Nil uchodził do morza. Herodot (ok. 485 - ok. 425) pisał w tym kontekście o trzech głównych i dwóch mniej znanych odnogach rzeki tworzących jej ujście, czyli w sumie wskazywał na pięcioramienną deltę Nilu, dodając przy tym, że istnieją jeszcze dwa inne ramiona Nilu, lecz, jego zdaniem, te nie były dziełem natury, lecz człowieka ${ }^{155}$. Ostatecznie zatem Herodot mówił o siedmiu ujściach delty Nilu, uważając przy tym dwa z nich za nienaturalne. Strabon ${ }^{156}$ wspomina także trzy ujścia główne, dodając do nich jeszcze cztery inne. Natomiast Pliniusz ${ }^{157}$ wymienia po prostu siedem ujść tej rzeki. Ta sama cyfra pojawia się u Ptolemeusza ${ }^{158}$. Jeśli pod kątem tych danych analizować poniższy graficzny przekaz na temat delty Nilu, wówczas wypada dostrzec silne zróżnicowanie rzeczonych schematów. Są bowiem mapy, które posiadają tylko prosty schemat ujścia Nilu w formie trójkąta (tab. XIII, rys. 4, 10-11, 16, 19, 21-22, 26 i 28). Kilka map ma natomiast wyraźnie zaznaczone trzy główne ramiona, tworzące deltę (tab. XIII, rys. 1-2, 7-9, 13, 18, 20, 23-25 i 27). Na niektórych zaś mapach w pozornie ,,jednolite" ujściu Nilu wstawiono kilka dość słabo widocznych dziś linii, które zdają się sugerować istnienie większej liczby ramiom delty (tab. XIII, rys. 5-6, 15 i 17). Są wreszcie mapy,

${ }^{147}$ Plinius, Naturalis historia III 121, ed. Mayhoff, vol. 1, s. 281, 11; tamże V 48, ed. Mayhoff, vol. 1, s. 380, 7-8; tamże V 50, ed. Mayhoff, vol. 1, s. 381, 8; tamże VI 165, ed. Mayhoff, vol. 1, s. $499,2$.

${ }^{148}$ Ammianus Marcellinus, Res gestae XXII 15, 12, rec. Gardthausen, vol. 1, s. 298, 17-19.

${ }^{149}$ Solinus, Collectanea rerum memorabilium 32, 1, rec. Mommsen, s. 154, 18-20.

${ }^{150}$ Martianus Capella, De nuptiis Philologiae et Mercurii VI 675, ed. Willis, s. 239, 20; tamże, V 676, ed. Willis, s. 240, 3 i 7.

${ }^{151}$ Dicuilus, Liber de mensura orbis terrae 6, 2, ed. Parthey, s. 21, 7; tamże 6, 6, ed. Parthey, s. 23,11 .

${ }^{152}$ Anonymus Leidensis, De situ orbis II 5, 1, ed. Quadri, s. 69, 18; tamże II 5, 2, ed. Quadri, s. 69, 23; tamże II 5, 3, ed. Quadri, s. 70, 5; tamże II 5, 10, ed. Quadri, s. 72, 22.

${ }^{153}$ Honorius Augustodunensis, Imago mundi I 17, ed. Flint, s. 57 (= PL 172, 126D).

${ }^{154}$ Gervasius Tilleberiensis, Otia imperialia II 3, ed. Banks \& Binns, s. 182.

${ }^{155}$ Herodotus, Historia II 17, ed. H. Kallenberg: Herodotus, Historia, editio altera, vol. 1, Lipsiae 1921, 133, $18-134,2$.

${ }^{156}$ Strabo, Geographica XVII 1, 18, C. 801, ed. Meineke, vol. 3I, s. 1117, 17-27.

${ }^{157}$ Plinius, Naturalis historia V 64, ed. Mayhoff, vol. 1, s. 387, 11-17.

${ }^{158}$ Ptolemaeus Claudius, Geographia IV 5, 10, ed. Nobbes, t. 1, s. 251, 18-28. Por. tamże IV 5, $38-42$, ed. Nobbes, t. 1, s. 257, 26 - 258, 13. W tym ostatnim fragmencie kilkakrotnie pojawia się termin delta. 
na których nakreślono jasno i wyraźnie wieloramienne ujście Nilu: w jednym przypadku jest ono sześcioramienne (tab. XIII, rys. 3), a w dwóch innych rzeka ma ujście siedmioramienne (tab. XIII, rys. 12 i 14). Schemat delty Nilu w kartografii średniowiecznej nie jest więc obrazem statycznym. Delta kartografów tego okresu posiada bowiem kilka wariantów, poczynając od prostego kształtu greckiej litery $\Delta$ po siedem odnóg rzeki, znanych zapewne nie tylko z lektury autorów antycznych, lecz być może także z ówczesnej tradycji ustnej, opartej na autopsji żeglarzy i kupców. Warto w tym miejscu zwrócić uwagę na fakt, że wielkość delty nie koresponduje z rozmiarami danej mapy. Za dowód może posłużyć mapa z Psałterza Londyńskiego (tab. XIII, rys. $14=\mathrm{A}^{1} / 52$ ), która pomimo średnicy $90 \mathrm{~mm}$ przedstawia siedmioramienne ujście Nilu. W grę wchodziła raczej indywidualna opcja konkretnego twórcy mapy oraz jego przygotowanie erudycyjne.

Tab. XIII: Delta Nilu - schemat

\begin{tabular}{|c|c|c|c|}
\hline & sisis & 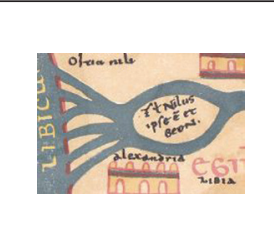 & 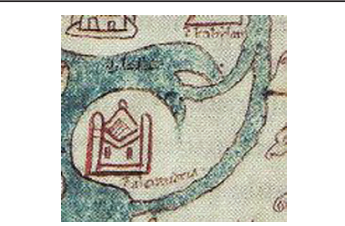 \\
\hline $\begin{array}{l}\text { 1. Mapa Beatusa } \\
\text { z Gerony } \\
(975)\left[\mathrm{A}^{1 / 7}\right]\end{array}$ & $\begin{array}{c}\text { 2. Cottoniana } \\
\text { (ok. 1030) }\left[\mathrm{A}^{1 / 15}\right]\end{array}$ & $\begin{array}{c}\text { 3. Mapa Beatusa } \\
\text { z Saint Séver }(1047- \\
\text { 1072) }\left[\mathrm{A}^{1 / 18}\right]\end{array}$ & $\begin{array}{l}\text { 4. Wiktoryńska mapa eku- } \\
\text { meny (XI/XII w.) }\left[\mathrm{A}^{1 / 25}\right]\end{array}$ \\
\hline & ce & & 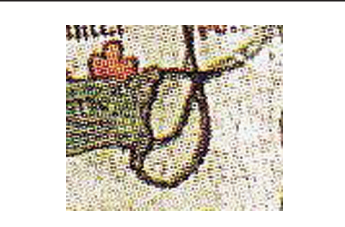 \\
\hline $\begin{array}{l}\text { 5. Mapa Beatusa } \\
\text { z Turyny (pocz. } \\
\text { XII w.) }\left[\mathrm{A}^{1 / 30}\right]\end{array}$ & $\begin{array}{l}\text { 6. Mapa z Sawley } \\
(1110 / 1180)\left[\mathrm{A}^{1 / 32}\right]\end{array}$ & $\begin{array}{l}\text { 7. Mapa hemisfe- } \\
\text { ryczna Lamberta } \\
\text { z Saint-Omer } \\
(1115 / 1180) \\
\text { [Wolfenb.] }\left[\mathrm{A}^{1 / 33}\right]\end{array}$ & $\begin{array}{c}\text { 8. Mapa hemisferyczna } \\
\text { Lamberta z Saint-Omer } \\
(1115 / 1300)[\text { Leiden }] \\
{\left[\mathrm{A}^{1 / 34}\right]}\end{array}$ \\
\hline & $\rightarrow$ & Find & \\
\hline $\begin{array}{l}\text { 9. Mapa } \mathrm{z}, \text {,The } \\
\text { Ryland Beatus” (ok. } \\
\text { 1175) }\left[\mathrm{A}^{1 / 40]}\right.\end{array}$ & $\begin{array}{c}\text { 10. Mapa O-T } \\
\text { z Paryża } \\
\text { (XII w.) }\left[\mathrm{A}^{1 / 39}\right]\end{array}$ & $\begin{array}{l}\text { 11. Mapa Beatusa } \\
\text { z Burgo de Osma } \\
(1086)\left[\mathrm{A}^{1 / 20}\right]\end{array}$ & $\begin{array}{c}\text { 12. Tabula Peutingeriana } \\
\text { (IV w. / kopia: XII/XIII w.) } \\
{\left[\mathrm{A}^{1} / 44\right]}\end{array}$ \\
\hline
\end{tabular}




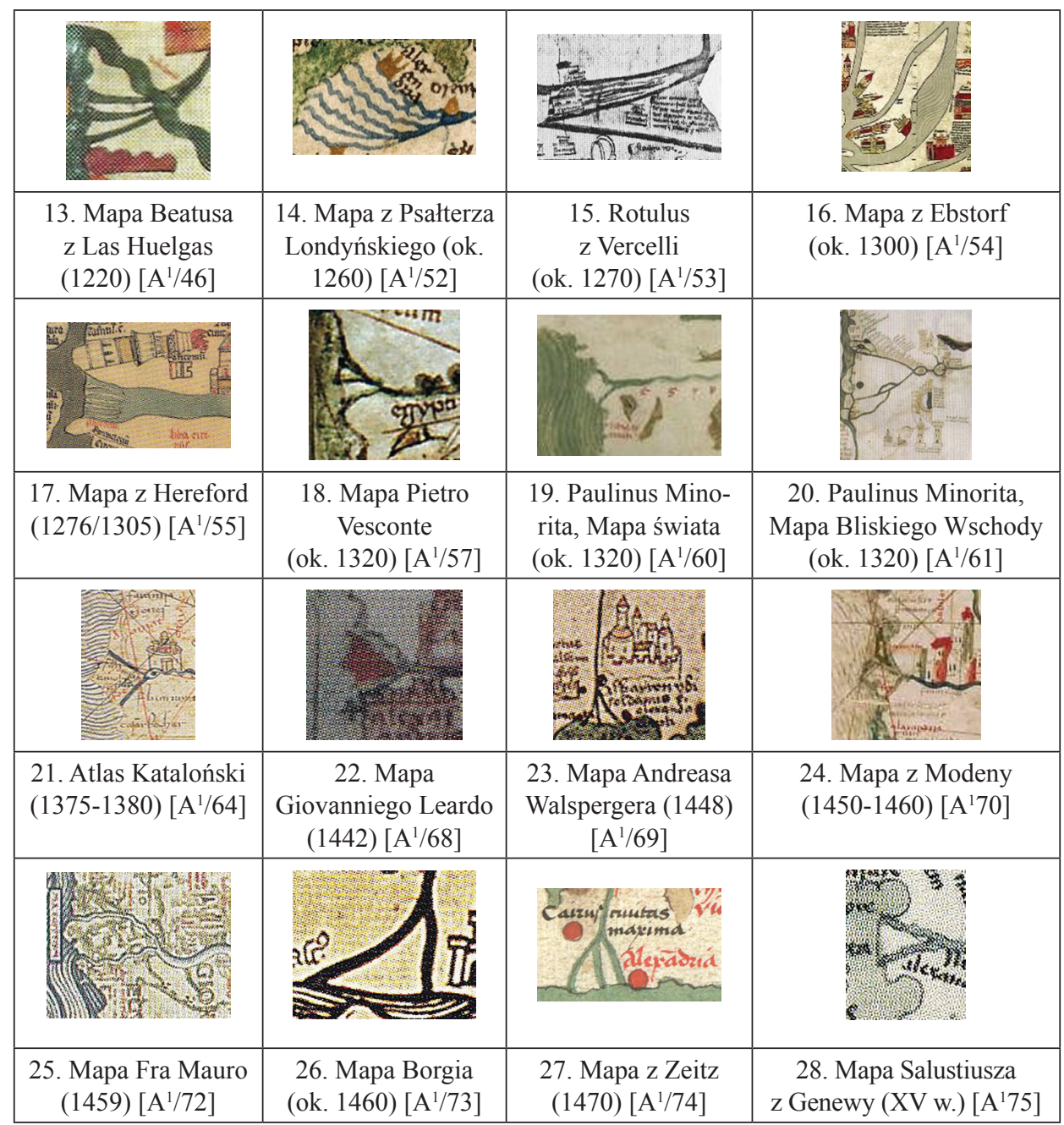

Nieco wyżej zostało już przywołane Wergiliuszowe pojęcie „Rhenus bicornis" ${ }^{159}$. Określenie to stosowano zapewne, jak sugeruje Serwiusz (IV/V w.), do wielu rzek posiadających dwa ujścia ${ }^{160}$, jednak ze szczególną predylekcją odnoszono je do Renu ${ }^{161}$. O jego znajomości w średniowieczu świadczą poniższe

${ }^{159}$ Por. przyp. 56. Por. też Ovidius, Tristia IV 2, 41-42, ed. R. Merkel: Ovidius, [Opera omnia], vol. 3, Lipsiae 1914, 65.

${ }^{160}$ Servius Grammaticus, In Vergilii carmina commentarii VIII 727, rec. G. Thilo: Servius Grammaticus, In Vergilii carmina commentarii, vol. 2: Aeneidos librorum VI-XII commentarii, Lipsiae 1884, 305: „Rhenus fluvius Galliae [...]. , bicornis' autem aut commune est omnibus fluviis, aut propria de Rheno, quia per duos alveos fluit: [...]”.

${ }^{161}$ Por. A. Riese, Rhenus bicornis, „Römisch-germanisches Korrespondenzblatt” 9 (1916) 77 78; R. Dion, Rhenus bicornis, „Revue des Études Latines” 42 (1964) 469-499; F. Gorissen, Rhe- 
mapy (tab. XIV), tym bardziej że „dwurożność” kojarzyła się nieodparcie z ujściem deltowatym. Jednak, jak widać(tab. XIV, rys. 2-3,5i 7), nie wszyscy kartografowie epoki rozumieli ów schemat jako trójkąt zarysowany wyłącznie przez dwie odnogi Renu. Wszyscy natomiast odwoływali się do schematu litery delta.

Tab. XIV: Delta Renu

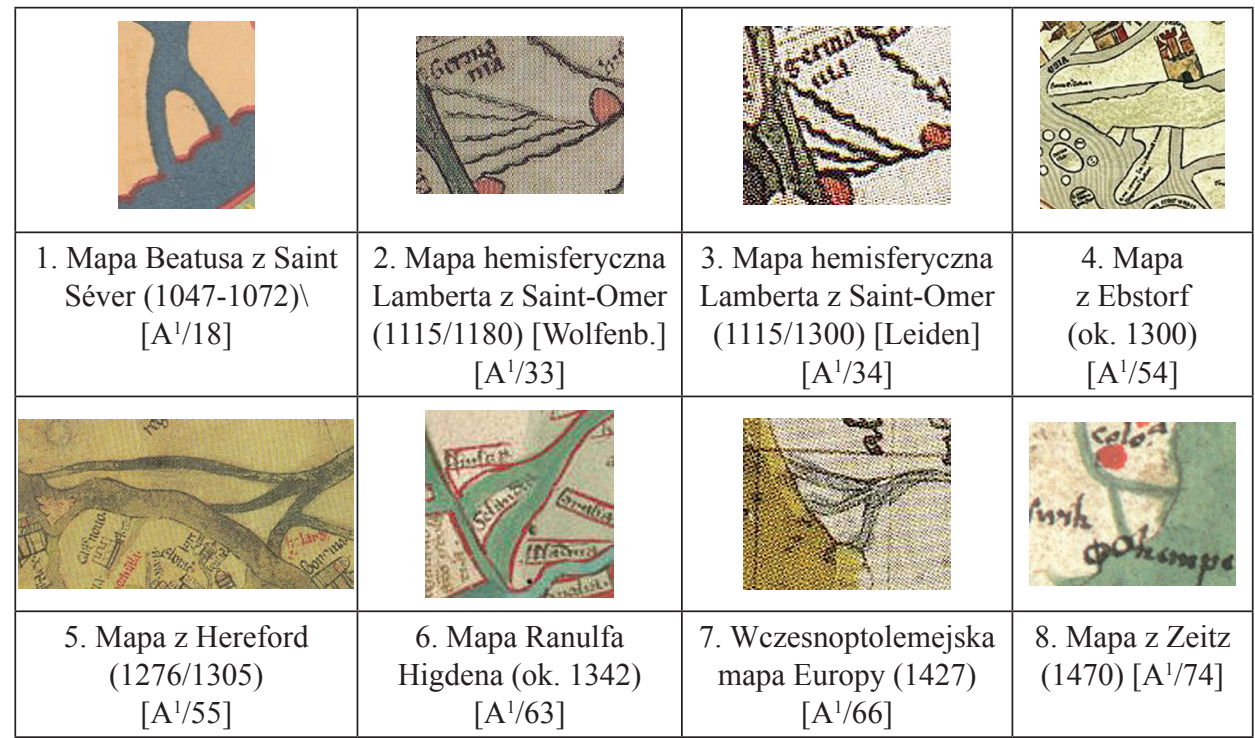

Drugą rzeką Europy, której ujściu mapy średniowieczne, zgodnie zresztą ze stanem faktycznym, nadawały formę delty był Dunaj (tab. XV). Już Herodot

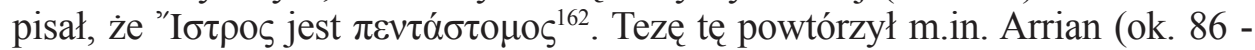
ok. 160 ${ }^{163}$. Plinius natomiast wspomina o sześciu ujściach Dunaju ${ }^{164}$. Starszy od niego Pomponiusz Mela zauważa z kolei, że Dunaj ma taką samą liczbę odnóg delty co Nil, a zatem siedem ${ }^{165}$. Ptolemeusz (ok. 100 - ok. 170) także przekazał schemat siedmiu ramion delty tej największej rzeki Europy ${ }^{166} \mathrm{i}$ ta cyfra weszła niejako do literackiej tradycji zachodnioeuropejskiej. Powtarza ją bowiem Am-

nus bicornis, w: Brückenschlag am Niederrhein: Land und Mensch am Niederrhein. Eine kulturgeographische Festschrift zur Einweihung der Rheinbrücke Kleve-Emmerich am 3.9.1965, hrsg. von J. Ruland, Niederrheinisches Jahrbuch 9, Düsseldorf 1965, 79-164; I. Östenberg, Staging the World. Spoils, Captives, and Representations in Roman Triumphal Procession, Oxford Studies in Ancient Culture, Oxford - New York 2009, 237-238; F. Cadiou, Géographie et ,pompa triumphalis” à Rome, „Geographia Antiqua” 19 (2010) 146.

${ }^{162}$ Herodotus, Historia IV 47, ed. Kallenberg, vol. 1, s. 341, 18.

${ }^{163}$ Arrianus, Alexandri anabasis V 4, 1, ed. A.G. Roos: Arrianus, Quae exstant omnia, vol. 1: Alexandri anabasis, Lipsiae 1907, 240, 21.

${ }^{164}$ Plinius, Naturalis historia IV 79, ed. Mayhoff, vol. 1, s. 336, 9-16.

${ }^{165}$ Pomponius Mela, De chorographia II 1, 8, rec. Frick, s. 29, 19-30.

${ }^{166}$ Ptolemaeus Claudius, Geographia III 10, 2-6, ed. Nobbes, t. 1, s. 182, 6 - 184, 12. 
mianus Marcellinus ${ }^{167}$, Solinus ${ }^{168}$, Izydor z Sewilli ${ }^{169}$ i Dicuil ${ }^{170}$. Za tą tezą poszło kilku średniowiecznych kartografów (tab. XV, rys. 1-3 i 8). Również idea pięciu ujść Dunaju znalazła swe odbicie na mapach tego okresu (tab. XV, rys. 9-10). Są także mapy, które odnoszą się tylko do schematu greckiej litery $\Delta$ (tab. XV, rys. 4 i 6-7), oraz takie, które ten „literowy” schemat nieco retuszuja, przedstawiając deltę Dunaju w formie trzech ramion (tab. XV, rys. 5). Generalnie jednak mapy stricte średniowieczne idą za schematem siedmiu odgałęzień, mających tworzyć ujście tej rzeki. Od tej koncepcji odchodzą natomiast mapy późniejsze, wczesnonowożytne, np. mapa Fra Mauro (tab. XV, rys. 9-A1/72) i mapa z Zeitz (tab. XV, rys. $10-\mathrm{A}^{1 / 74}$ ), przedstawiając deltę o pięciu ujściach. $Z$ jednej strony ten swoisty powrót do starszej tradycji wywodzącej się przynajmniej od Herodota można tłumaczyć rozwojem studiów nad autorami starożytnymi w dobie renesansu. W tym sensie byłby to swego rodzaju graficzny powrót do źródeł. Z drugiej zaś strony, szczególnie w przypadku mieszkańca Wenecji, jakim był Fra Mauro (ok. 1385 - ok. 1460), można przypuszczać, że kartograf kierował się opiniami współczesnych mu żeglarzy. Mógł zatem uważać, że dzięki informacjom z pierwszej ręki poprawia nieścisłości swych poprzedników i daje swym następcom rzeczywisty obraz delty Dunaju.

Tab. XV: Delta Dunaju

\begin{tabular}{|c|c|c|c|}
\hline $\begin{array}{lll}0 \\
3 \\
3 \\
0\end{array}$ & 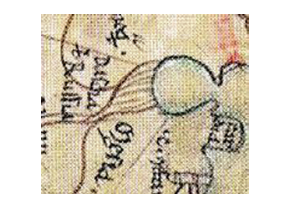 & 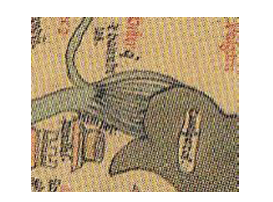 & 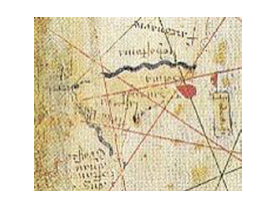 \\
\hline $\begin{array}{l}\text { 1. Mapa Beatusa } \\
\text { z Saint Séver } \\
(1047-1072)\left[\mathrm{A}^{1 / 18}\right]\end{array}$ & $\begin{array}{l}\text { 2. Mapa z Sawley } \\
(1110 / 1180)\left[\mathrm{A}^{1 / 32}\right]\end{array}$ & $\begin{array}{l}\text { 3. Mapa z Hereford } \\
(1276 / 1305)\left[\mathrm{A}^{1 / 55}\right]\end{array}$ & $\begin{array}{l}\text { 4. Atlas Kataloński } \\
(1375-1380)\left[\mathrm{A}^{1 / 64}\right]\end{array}$ \\
\hline$\left(\begin{array}{l}3 \\
\cos ^{2}\end{array}\right.$ & & & $5=$ \\
\hline $\begin{array}{c}\text { 5. Wczesnoptolemejska } \\
\text { mapa Europy }(1427) \\
{\left[\mathrm{A}^{1 / 66}\right]}\end{array}$ & $\begin{array}{l}\text { 6. Mapa Giovanniego } \\
\text { Leardo (1442) }\left[\mathrm{A}^{1 / 68}\right]\end{array}$ & $\begin{array}{l}\text { 7. Mapa z Modeny } \\
(1450-1460)\left[\mathrm{A}^{1 / 70}\right]\end{array}$ & $\begin{array}{l}\text { 8. Mapa Genueńska } \\
\text { (1457) }\left[\mathrm{A}^{1 / 71}\right]\end{array}$ \\
\hline
\end{tabular}

${ }^{167}$ Ammianus Marcellinus, Res gestae XXII 8, 45, rec. Gardthausen, vol. 1, s. 283, 13-19.

${ }^{168}$ Solinus, Collectanea rerum memorabilium 13, 1, rec. Mommsen, s. 90, 12: „Septem ostiis Pontum fluit".

${ }^{169}$ Isidorus Hispalensis, Etymologiae XIII 21, 28, PL 82, 493C: „Septem ostiis Pontum fluit”.

${ }^{170}$ Dicuilus, Liber de mensura orbis terrae 6, 36, ed. Parthey, s. 35, 15: „Septem ostiis Pontum fluit"; tamże 6,36, ed. Parthey, s. 16-21: tutaj autor wylicza imiennie owych siedem ujść Dunaju do Morza Czarnego. 


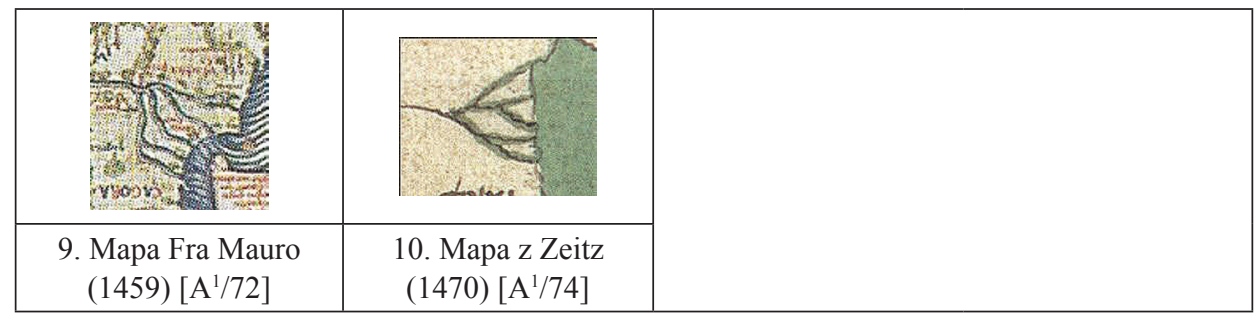

Tradycja na temat ujścia Gangesu mówi także o delcie tej rzeki. Pomponiusz Mela pisze nawet o siedmiu jej gardłach ${ }^{171}$. Przekaz Ptolemeusz z kolei wspomi-

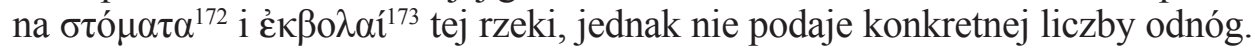
Kartografowie omawianego tutaj okresu przedstawiali, jak prezentuje to poniższa tabela (XVI), wpływ Gangesu do oceanu, stosując grosso modo najprostszy schemat delty. Zapewne jednak nikt $\mathrm{z}$ nich nie zdawał sobie sprawy $\mathrm{z}$ systemu hydrograficznego ujścia Gangesu oraz z jego ogromu. Tylko bowiem w ten sposób da się wytłumaczyć prostotę, czy wręcz naiwność tego przedstawienia graficznego. Można też spojrzeć na całą sprawę zupełnie inaczej i stwierdzić, że owa prostota jest dowodem odpowiedzialność czy też pokory ówczesnych twórców map, którzy kreśląc najprostszy z możliwych schematów delty pozostawiali de facto otwartą kwestię rzeczywistego obrazu systemu hydrograficznego dolnego biegu Gangesu. Jeszcze innym hipotetycznym sposobem wyjaśnienia tego zagadnienia może być wskazanie na to, że deltę Gangesu rysowano analogicznie do teoretycznie lepiej znanej delty Indusu, o czym niżej.

Tab. XVI: Delta Gangesu

\begin{tabular}{|c|c|c|c|}
\hline & & \\
\hline
\end{tabular}

${ }^{171}$ Pomponius Mela, De chorographia III 7, 68, rec. Frick, s. 283, 13-14.

${ }_{172}$ Ptolemaeus Claudius, Geographia VII 1, 81, ed. Nobbes, t. 2, s. 157, 11.

${ }^{173}$ Tamże VII 4, 6, ed. Nobbes, t. 2, s. 174, 3. 
$\mathrm{Na}$ temat delty Indusu starożytność dysponowała teoretycznie przekazami naocznych świadków z okresu zdobywczej wyprawy Aleksandra Macedońskiego (356-323 prz. Chr.), którzy mówili o dwóch odnogach rzeki uchodzących do oceanu ${ }^{174}$. Jednakże przekaz ten, jak wiadomo, był bardzo dużym uproszczeniem, a ponadto pochodził z drugiej ręki. Tradycja ta została przejęta zarówno przez pisarzy okresu cesarstwa, jak i przez średniowieczną literaturę łacińską ${ }^{175}$. W ten sposób powstał kolejny topos literacki, z którego wyłamuje się tylko relacja Ptolemeusza, piszącego o siedmiu ramionach delty Indusu ${ }^{176}$. Jednak w zachowanej spuściźnie kartograficzej jego opinia nie znalazła żadnego odzwierciedlenia. Poza tym delta Indusu była przedstawiana graficznie bardzo rzadko. Jej schemat widnieje zaledwie na kilku i to późnych mapach (tab. XVII), i sygnalizuje on z jednej strony mglistą wiedzą ich twórców na temat kształtu dolnego odcinka tej rzeki, z drugiej zaś, podobnie jak w przypadku delty Gangesu, mogła nimi kierować zwykła uczciwość, która nakazywała pominąć niepewne detale, rysując tylko kontury trójkąta.

Tab. XVII: Delta Indusu

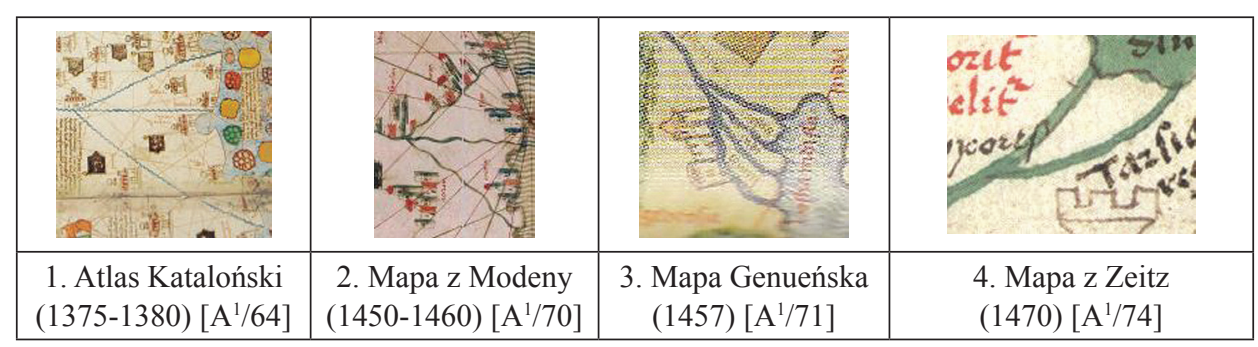

Grafika map analizowanego tutaj okresu nie ogranicza się rzecz jasna do przedstawionych wyżej pięciu rzek. Sieć rzeczna zajmuje bowiem poczesne, rzec by można, miejsce na przedmiotowych mapach, choćby $\mathrm{z}$ tego powodu, że stanowi ona ich element ,zdobniczy”. Poza tym w krajobrazie Europy rzeka jako taka jest czymś naturalnym, będąc jednocześnie jednym z ważnych symboli życia. Jednak takie rzeki jak Nil, Dunaj, Ganges i Indus miały jeszcze inną cechę, która kazała patrzeć na nie z pewną estymą. Były one bowiem obok Eufratu i Tygrysu brane pod uwage jako odpowiedniki dwóch pierwszych rzek Edenu, a mianowicie Piszonu i Gichonu (Rdz 1, 11-13). Nie tutaj jednak miejsce na szersze przedstawienie tej skądinąd bardzo ciekawej kwestii. Jednak fakt ten thumaczy do pewnego stopnia to, że starano się wszystkie

${ }^{174}$ Por. Kochanek, Iluzja schematów choro- i topograficznych, s. 85, przyp. 47-48. Tutaj zebrano źródła dotyczące tej kwestii.

${ }^{175}$ Por. Pomponius Mela, De chorographia III 7, 69, rec. Frick, s. 71, 20-21; Plinius, Naturalis historia VI 80, ed. Mayhoff, vol. 1, s. 464, 1-2; Arrianus, Alexandri anabasis V 4, 1, ed. Roos, vol. 1, s. 240, 20; Avienus, Descriptio orbis terrae 1294-1295, w: Geographi Graeci Minores, vol. 2, s. 188; Dicuilus, Liber de mensura orbis terrae 7, 24, ed. Parthey, s. 49, 1-2.

${ }^{176}$ Ptolemaeus Claudius, Geographia VII 1, 2, ed. Nobbes, t. 2, s. 141, 14-22; tamże VII 1, 28 , ed. Nobbes, t. 2, s. 146, $26-147,8$. 
ich ujścia określać mianem delty, a tym samym wskazać na łączące je podobieństwo. Ponadto jako potencjalne rzeki rajskie były one na swój sposób rzekami pierworodnymi, ponieważ biblijny Eden jawi się de facto jako pierwszy zagospodarowany skrawek stworzonej przez Boga ekumeny i to skrawek, o którego „wystrój” zatroszczył się sam Stwórca. W tym właśnie sensie rzeki te zajmują w dziele stworzenia miejsce specjalne jako rzeki pierworodne świata stworzonego. Tego zaś autorzy map, wywodzący się zwykle ze środowiska monastycznego, nie mogli nie dostrzegać. Graficzne wyeksponowanie tych rzek nie może być więc traktowane jako dzieło przypadku, lecz jako element kultury teologicznej tego okresu.

Po rozważaniach chorograficznych wypada wspomnieć jeszcze o ważnym z geopolitycznego punktu widzenia wątku topograficznym, dobrze zaznaczonym graficznie na wielu mapach średniowiecznych i wczesnonowożytnych. Chodzi tutaj o motyw naturalnych pasaży górskich, czyli tzw. wrót lub bram, zwanych z łacińska portae. W antycznych traktatach geograficznych, a przede wszystkim w „Geografii” Strabona i Ptolemeusza pojawia się wręcz litania „bram”. Są tu m.in. „Portae Albaniae”, „Portae Amanicae”, „Portae Caspiae”, „Portae Ciliciae”, „Portae Gaditanae”, „Portae Persicae”, „Portae Sarmaticae”, czy „Portae Syriae”177. Z tych licznych przejść w kartografii omawianego tutaj okresu szczególne miejsce zajmują dwie bramy: „Portae Caspiae” i „Portae Nubiae” (tab. XVIII). Na mapach „Portae Caspiae” znajdują się w północnowschodniej części ekumeny, natomiast „Portae Nubiae” widnieją na jej południowo-wschodnich obszarach. Są więc one ustawione niejako w opozycji do siebie. Opozycja ta nie jest przypadkowa. Jest ona de facto oparta na patrystycznej i średniowiecznej egzegezie wersu Pieśni nad Pieśniami (Pnp 4, 16): „surge aquilo et veni auster perfla hortum meum et fluant aromata illius" ${ }^{178}$. Egzegeci tego okresu dostrzegali wyraźną antytezę pomiędzy wiatrem z Północy (Aquilo) a wiatrem z Południa (Auster). Pierwszy z nich interpretowali jako zmrażające wszystko tchnienie diabła, drugi zaś jako ożywcze tchnienie Ducha Swiętego ${ }^{179}$. W konsekwencji „Portae Caspiae” są w kartografii

${ }^{177}$ Por. Kochanek, Iluzja schematów choro- i topograficznych, s. 119-120 oraz s. 120, przyp. 226-229. Tam znajduje się również odpowiednia bibliografia.

${ }^{178}$ Tekst łaciński cytowany za: Biblia sacra iuxta Vulgatam versionem, praeparavit R. Gryson, Vierte, verbesserte Auflage, Stuttgart 1994, s. 999. W tym kontekście należy również wspomnieć Psalm 126 (Wulgata 125) wers 4: „converte Domine captivitatem nostram sicut torrens in austro” - tamże, s. 932. Do tego trzeba dodać wypowiedzi proroków na temat tzw. wroga z Północy, szczególnie Ezechiela i Jeremiasza, por. Kochanek, Die Vorstellung vom Norden und der Eurozentrismus, s. 34-38.

${ }^{179}$ Por. Ambrosius, De virginitate I 10, 54, ed. E. Cazzaniga, Corpus Scriptorum Latinorum Paravianum, Torino 1954, 25, 22 - 26, 2 (= PL 16, 294A); Augustinus, Enarrationes in Psalmos CXXV 10, 34-35, ed. F. Gori: Augustinus, Enarrationes in Psalmos 101-150, pars I: Enarrationes in Ps. 119-133, CSEL 95/3, Wien 2001, 178 (= PL 36, 1664); Eucherius Lugdunensis, Formulae spiritualis intelligentiae II, rec. C. Wotke: Eucherius Lugdunensis, Formulae spiritualis intelligentiae, Instruc- 
średniowiecznej i wczesnonowożytnej kojarzone z biblijnym wrogiem z Północy czyli z Gogiem (Ez 38-39) oraz z ideą tzw. ludów zamkniętych, które to zagadnienie zostało już przez niżej podpisanego szczegółowo przeanalizowane w innym opracowaniu ${ }^{180}$. Wrota Kaspijskie oddzielają te barbarzyńskie ludy od reszty ekumeny, stanowiąc swego rodzaju zawór bezpieczeństwa dla cywilizacji chrześcijańskiej. Z kolei „Portae Nubiae”, którym osobny artykuł poświęciła swego czasu Anna-Dorothee von den Brincken ${ }^{181}$, znajdują się w części ekumeny kojarzonej z owym tchnieniem Ducha Świętego. W ten sposób mapy tego okresu przedstawiają graficznie symetrię osiową pomiędzy krainą szatana a krainą Ducha Świętego. Tutaj warto spojrzeć na tę kwestię

tiones, Passio agaunensium martyrum, Epistula ad laudem Heremi, CSEL 31, Pragae - Vindobonae - Lipsiae 1894, 11, 14 i 20 (= PL 50, 740D i 741A); Eugyppius, Excerpta ex operibus S. Augustini 219, 237, ed. P. Knoell: Eugyppius, Excerpta ex operibus S. Augustini, CSEL 9/1, Vindobonae 1885, 698, 7-13 (= PL 62, 889D); Gregorius Magnus, Homiliae in Ezechielem prophetam II 1, 6, 189-193, ed. M. Adriaen: Gregorius Magnus, Homiliae in Ezechielem prophetam, CCL 142, Turnholti 1971, 212 (= SCh 360, 60 = PL 76, 939D); Gregorius Magnus, Moralia in Iob XXVIII 38, 63, 13-17, ed. M. Adriaen: Gregorius Magnus, Moralia in Iob libri XXIII-XXXV, CCL 143B, Turnholti 1985, 1381 (= PL 76, 437A); Beda Venerabilis, In Cantica canticorum libri III VI 429-436, ed. D. Hurst: Beda Venerabilis, Opera, pars II: Opera exegetica, 2B: In Tobiam, In Provenbia, In Cantica canticorum, In Habacuc, CCL 119B, Turnholti 1983, 370 (= PL 91, 1232A-B); Alcuinus, Enchiridion CXXV, PL 100, 627D; tenże, Commentaria in Apocalypsin III 3, PL 100, 1113C; Haymo Halberstatensis, Expositio in Apocalypsin II 3, PL 117, 996C; Bruno Carthusianorum, Expositio in Psalmos CXXV, PL 152, 1327A; Anselmus Laudunensis, Enarrationes in Cantica canticorum, IV, PL 162, 1210B; Guibertus S. Mariae de Novigento, Morialia in Genesin, VII 24, PL 156, 192C; Hildebertus Cenomanensis, Sermones, CXXI, PL 171, 894B i 894D; Hugo de S. Victore, Miscellanea, I 173, PL 177, 571B; Guillelmus Malmesburiensis, Abbreviatio Amalarii, I 1, ed. Th.D. Pfaff: tenże, The „Abbreviatio Amalarii" of William of Malmesbury. Text, RTAM 48 (1981) 131; Guillelmus a Sancto Theodorico, Excerpta ex libris beati Gregorii super Cantica canticorum, IV 16, 272-286, ed. P. Verdeyen: Guillelmus a Sancto Theodorico, Opera omnia, pars II, CCCM 87, Turnholti 1987, 427 (= PL 180, 462C-D); Absalon Sprinckirsbacensis, Sermones XXXVI, PL 211, 210A i 213B; Godefridus Admontensis, Liber de decem oneribus Isaiae VII, PL 174, 1190A; Aelredus Rievallensis, Sermo in adventu Domini 15, PL 184, 824C; Gerhohus Reicherspergensis, Expositio in Psalmos (continuatio) CXLVII, PL 194, 982C; tenże, Expositio in canticum Habacuc, PL 194, 1038A; Hildegardis Bingenesis, Epistolae XLIX (Responsum Hildegardis), PL 197, 254A-B; Documenta historica quae ad sanctum Thomam Cantuariensem pertinent XIII, PL 190, 420C; Alanus de Insulis, Elucidatio in Cantica canticorum IV, PL 210, 83D; tenże, Dictiones dictionum theologicalium A, PL 210, 706C, 711B i 715D. Por. też Forstner, Świat symboliki chrześcijańskiej, s. 72; Th.D. Hill, The Tropological Context of Heat and Cold Imagery in Anglosaxon Poetry, „Neuphilologische Mitteilungen” 69 (1968) nr 4, s. 527; B.T. Coolman, The Theology of Hugh of St. Victor. An Interpretation, Cambridge 2010, 207.

${ }^{180}$ Por. Kochanek, Klauzura pótnocno-wschodniej Azji, passim. W kontekście niniejszych analiz szczególnie ważne są znajdujące się tam tabelaryczne zestawienia winiet Wrót Kaspijskich: s. 330, tab. IV; s. 331, tab. V; s. 332-333, tab. VI.

${ }^{181}$ A.-D. von den Brincken, Spuren Nubiens in der abendländischen Universalkartographie im 12. bis 15. Jahrhundert, w: Vom „,Troglodytenland” ins Reich der Scheherazade. Archäologie, Kunst und Religion zwischen Okzident und Orient. Festschrift für Piotr O. Scholz zum 70. Geburtstag, hrsg. von M. Długosz, Berlin 2014, 46-48. 
w kontekście powyższego wersu Pieśni nad Pieśniami, który wprowadza paralelizm między diaboliczną Północą, a napełnionym tchnieniem Ducha Świętego Południem. Nie chodzi przy tym o analizę wszystkich zachowanych map średniowiecznych i wczesnonowożytnych w aspekcie ich graficznej prezentacji Wrót Nubijskich, ponieważ to wymaga osobnego studium, lecz o przedstawienie kilku instruktywnych przypadków wspomnianego paralelizmu.

Niniejszy wywód wypada rozpocząć od tzw. Cottoniany (tab. XVIII/1 $\left.=\mathrm{A}^{1} / 15\right)$, która powstała około roku 1030 . Nie posiada one graficznego wyobrażenia Wrót Nubijskich, jednak prezentuje interesujący schemat sytuacyjny regionu, gdzie owa brama powinna się znajdować. Jej autor narysował bowiem znaczące przewężenie między źródłami Nilu a Morzem Czerwonym. Pod nim zaś umieścił legendę: „Egiptus superior”. Z kolei obok przewężenia, w górnym biegu rzeki znajduje się legenda: „Fluvius Nilus”. Natomiast nad nią widoczny jest schemat góry oraz napis: „Hic dicitur esse mons super [zamiast: semper] ardens"182. Jest to zatem nie tyle obraz samej Bramy Nubijskiej, co pewna graficzny intuicja, sugerujący istnienie zamkniętego obszaru w obrębie południowo-wschodniej Afryki. Trzeba też zauważyć, autor mapy podobnie postapił $\mathrm{w}$ przypadku Wrót Kaspijskich, których explicite również nie zaznaczy $1^{183}$, pozostawiając to intuicji czytelnika swej mapy. Jest też możliwe, że bądź ówczesna sytuacja geopolityczna nie wymagała od niego tego rodzaju odniesień, bądź też (całkiem po prostu) nie było to jego zamierzeniem. Ponieważ jednak wewnętrza logika grafiki mapy dowodzi, że jej twórca posiadał świadoność istnienia tych paralelnych krain, zatem można założyć, że ów sposób widzenia północno-wschodnich obszarów Azji i południowo-wschodnich terenów Afryki był w tym okresie czymś oczywistym.

Nieco inaczej przedstawia się ta sprawa na tzw. Wiktoryńskiej mapie ekumeny (tab. XVIII/2 $=\mathrm{A}^{1} / 25$ ), datowanej na przełom XI i XII w. Nie posiada ona co prawda Wrót Nubijskich jako takich, jednak została na niej jednoznacznie wyróżniona klauzura południowo-wschodniej Afryki w formie trójkątnego półwyspu, który od zachodu zamyka potężne pasmo górskie. Reszty zaś dopełniają legendy. Znajdujący się na samym cyplu półwyspu tekst łaciński brzmi: „Archipoleta lacus quem Nilus ingreditur”. Niżej, gdzie zaznaczono drugie źródło tej rzeki, napis głosi: „hinc Nilus emergit”, a tuż pod nim dodano krótkie objaśnienie: „Ethiopum deserta loca”. Natomiast po drugiej stronie pasma górskiego zamykającego klauzurę widoczne są dwie solidna „wieże”, a umieszczona nad nimi legenda wyjaśnia, że są to „monasteria monachorum Egypti”. Z kolei za rzeką po prawej stronie ,wież” zlokalizowano objaśnienie: „Egyptiaca deserta”, zaś po lewej, tuż nad głową znajdującego się tam

${ }^{182}$ Tekst legend za: Miller, Mappaemundi. Die ältesten Weltkarten, III. Heft, s. 34-35. Por. M.F. le Vicomte de Santarem, Essai sur l'histoire de la cosmographie et de la cartographie pendant le MoyenÂge, t. 2, Paris 1850, 50 i 73.

${ }^{183}$ Por. P. Kochanek, Klauzura pótnocno-wschodniej Azji, s. 215, ryc. 4; s. 220 i ryc. 14. 
zwierzęcia widnieje słowo „serpentes” ${ }^{184}$. Zatem autor mapy wskazuje jednoznacznie, że góry separują od siebie Etiopię i Egipt. Co więcej, przed barierą górską umieszcza dwie winiety chrześcijańskich klasztorów. Obszar południowo-wschodniej Afryki jest więc obszarem zamkniętym, choć w nieco inny sposób niż klauzura północno-wschodniej Azji. Różnica polega na tym, że enklawa azjatycka posiada wyraźnie narysowane Wrota Kaspijskie ${ }^{185}$, podczas gdy przedmiotowe terytorium afrykańskie jest szczelnie odseparowane od reszty tego kontynentu. Autor mapy pragnął zapewne zaznaczyć w ten sposób swego rodzaju przepaść, dzielącą terytorium podległego islamowi Egiptu od Etiopii. Mają to dodatkowo podkreślać dwie bliźniacze winiety klasztorów egipskich, które przypominają bramę obronną flankowaną przez dwie wieże, stanowiącą forpocztę terytorium Etiopii, zamieszkałe przez chrześcijan. W połączeniu ze znajdującym się za nimi pasmem górskich, symbolizującym de facto mur, można tę kompozycję graficzną uznać za substytut Wrót Nubijskich, zarysowanych zaledwie implicite z tylko autorowi mapy znanych powodów. Explicite tymczasem klauzura południowo-wschodniej Afryki jest całkowicie odseparowana od Egiptu, podczas gdy enklawa północno-wschodniej Azji posiada zrobione ręką ludzką wrota. Jest zatem pewna możliwość przejścia na obszar północno-wschodniego barbaricum, której brak w przypadku południowego pogranicza muzułmańsko-chrześcijańskiego. Jest to niewątpliwie interesująca hierarchizacja stopnia separacji poszczególnych kultur ekumeny, widziana oczyma średniowiecznego, wykształconego człowieka Zachodu.

Na mapie z Sawley (tab. XVIII/3 = A 1/32), zwanej dawniej mapą Henryka z Moguncji, która miała powstać między rokiem 1110 a 1180, realistycznej winiecie Wrót Nubijskich towarzyszy legenda „Porte Nibie”, które są „wbudowane” w „Montes Nibie”. Góry te biegną między Morzem Czerwonym a pasem oceaniczym otaczającym ekumenę, tworząc z południowo-wschodniej części Afryki trójkątny półwysep. Na półwyspie tym znajdują się jeszcze dwie legendy: „Fialus fons Nili” oraz „Mons Ardens”"186. Ta ostatnia góra widnieje na samym cyplu rzeczonego półwyspu. O ile jednak Brama Nubijska jest przedstawiona graficznie $\mathrm{w}$ formie wrót, o tyle ich antytetyczny odpowiednik w północno-wschodniej części Azji, czyli Brama Kaspijska, został narysowany w formie naturalnego pasażu, znajdującego się między dwoma pasmami górskimi ${ }^{187}$. Wyjaśnienie tej graficznej różnicy może być tylko hipotetyczne. Kontrast pomiędzy stworzoną przez naturę górską doliną, a wykonaną ręką

${ }^{184}$ Tekst legend za: P. Gautier-Dalché, La „Descriptio mappe mundi” de Hugues de Saint-Victor. Texte inédit avec introduction et commentaire, Paris 1988, 195.

${ }^{185}$ Por. Kochanek, Klauzura pótnocno-wschodniej Azji, s. 224, ryc. 18; s. 227, ryc. 24A; s. 229-

231 oraz ryc. $26 \mathrm{G} ;$ s. 331 , tab. V/1.

${ }^{186}$ Tekst legend za: Lecoq, La mappemonde d'Henri de Mayence, s. 162 (nr 29-32). Por. Miller, Mappaemundi. Die ältesten Weltkarten, III. Heft, s. 26-27.

${ }^{187}$ Por. Kochanek, Klauzura pótnocno-wschodniej Azji, s. 224, ryc. 19; s. 229, ryc. 25A; s. 330, tab. IV/3. 
ludzką bramą zdaje się wskazywać na prymitywizm barbarzyńców z Północy przeciwstawiony talentowi architektonicznemu Południa. Byłby to zatem graficzny powrót do antycznej oraz patrystycznej, a przypominanej jeszcze w średniowieczu tezy o tępocie umysłowej ludów Północy i będącego jej efektem zapóźnienia cywilizacyjnego tej części ekumeny ${ }^{188}$. Dodatkowo, w światle zarysowanej wyżej opozycji między „diaboliczną” Północą a Południem, będącym domeną Ducha św., owa tępota jest tutaj łączona pośrednio acz dobitnie z destrukcyjnym wpływem szatana na ludzki umysł jako taki. Niszczy on bowiem człowieka nie tylko poprzez wciaganie go w grzech, czyli w sferze etyczno-moralnej, lecz wpływa także destrukcyjnie na wszystkie sfery jego życia. W konsekwencji zaś nie pozwala człowiekowi wydobyć się ze stanu pierwotnego barbarzyństwa. Temu rudymentarnemu poziomowi egzystencji grafika mapy przeciwstawia zdolność do budowy rzeczy monumentalnych, co nie dziwi w epoce wznoszenia katedr. Jest jednak i druga strona tegoż medalu. Naturalny pasaż północny, choć teoretycznie łatwy do zablokowania, jest otwarty. Innymi słowy zagrożenie płynące z Północy nie jest tutaj silnie eksponowane. Rysunek zdaje się wręcz sugerować możliwość jakiegoś dialogu ograniczonej formy wzajemnej komunikacji. Tymczasem zamknięta szczelnie brama południowo-wschodniej enklawy każe raczej porzucić nadzieję na jakąkolwiek formę wzajemnego porozumiewania się. Jest to jednak brama, którą potencjalnie można w każdej chwili uchylić, na co nie pozwola monolityczna ściana gór w przypadku omówionej wyżej tzw. Wiktoryńskiej mapy ekumeny.

Również na mapie z Psałterza Londyńskiego (tab. XVIII/4 $=\mathrm{A}^{1 / 52}$ ) góry i wrota tworzą trójkątny półwysep, w który wpisano następujące legendy: „Ethiopia”, „Nilus fl.” i „stannum”. Zaś przed samymi Bramami Nubijskimi, które nie posiadają własnej legendy, widnieje termin „Egyptus” ${ }^{189} \mathrm{~W}$ ten sposób powstaje dobrze czytelna struktura geopolityczna. Oto Wrota Nubijskie oddzielają terytorium zwane „Egyptus” od obszaru objętego nazwą „Ethiopia”. Innymi słowa oddzielają one obszar zamieszkały przez chrześcijan od muzułmańskiego kraju nad środkowym i dolnym biegiem Nilu. Warto jednak podkreślić istnienie owej graficznie zaznaczonej bramy, co oznacza rodzaj możliwej do otwarcia, przysłowiowej furtki. Trzeba również zaznaczyć, że prawie identyczną z graficznego punktu widzenia bramę posiada na tej mapie klauzura północno-wschodniej Azji ${ }^{190}$. Sugeruje to, że w oczach rysownika rzeczonej miniatury obie enklawy zostały potraktowane jednakowo. Wskazana w ten sposób równowaga może być interpretowana na różne sposoby, jednak w każdym przypadku jest to pewien cień nadziei na dialog, cokolwiek rozumiano by pod tym pojęciem.

${ }^{188}$ Zbiór źródeł na ten temat znajduje się w: Kochanek, Die Vorstellung vom Norden und der Eurozentrismus, s. 226-227, przyp. 234; tenże, Etnomedycyna hippokratejska a geopolityczna myśl grecka, s. 36-38, przyp. 34-35.

${ }^{189}$ Tekst legend za: Miller, Mappaemundi. Die ältesten Weltkarten, III. Heft, s. 41.

${ }^{190}$ Por. Kochanek, Klauzura pótnocno-wschodniej Azji, s. 224, ryc. 20; s. 227, ryc. 24B; s. 331, tab. $\mathrm{V} / 2$. 
Podobną logikę odnaleźć można na Rotulusie z Vercelli (tab. XVIII/5 $=\mathrm{A}^{1 / 53}$ ). Niestety obszerne legendy tej części rzeczonej mapy są dla autora niniejszego artykułu nieczytelne. Również mało czytelne są winiety na kopiach Rotulusa, będących do dyspozycji niżej podpisanego. W tym stanie rzeczy można tylko stwierdzić, że sam obszar enklawy południowo-wschodniej Afryki nie posiada bramy zaznaczonej tak wyraźnie, jak ufortyfikowana budowla bramna zamykająca na tejże mapie klauzurę północno-wschodniej Azji ${ }^{191}$. Biorąc pod uwagę zasygnalizowane wyżej trudności wypada uznać, że logika grafiki enklawy południowo-wschodniej Afryki na przedmiotowej mapie przywodzi na myśl wcześniej analizowane miniatury. Jednak z powodu braku możliwości odczytania treści znajdujący się tam legend, należy wstrzymać się z próbą poważnego rozpracowania tej geograficznej klauzury.

Inaczej ma się rzecz z mapą z Ebstorf (tab. XVIII/6 = $\mathrm{A}^{1 / 54}$ ). Ze względu na jej dużą powierzchnię południowo-wschodnia enklawa została zaopatrzona w szereg rozbudowanych legend. Klauzura ta jest podzielona de facto na dwa paralelne pasy. Pierwszy z nich znajduje się zarówno pod jak i nad winietą Wrót Nubijskich strzeżonych przez dwóch nagich wojowników zaopatrzonych w hełmy, tarcze i włócznie. Pod nimi umieszczono następującą legendą: „Porte Nybie, Caspiarum similes, ubi custodie Nybiarum posite aditum prebent advenarum. Distat a Sais civitate Egypti itinere LXX dierum" ${ }^{192}$. Z kolei bezpośrednio nad Wrotami Nubijskimi widnieje winieta miasta opatrzona legendą: „Nybia civitas” ${ }^{193}$. Natomiast nad przedmiotową winietą znajduje się długa, uszkodzona legenda, którą Harmut Kugler częściowo rekonstruuje, poprzestając ostatecznie na następującym tekście: „Locus qui dicitur Moyse id est aque ortus. Qui hic habitant, Nibei vocantur. Gens hec est semper nuda... um modum veridica, christianissima, auro dives est; negotio vivit; tres habet reges et totidem episcopos. Ierusalem cum multa turma et cum multa pecunia frequenter venit et sepulchrum Domini multa pecunia honorat et ditat"194. Wreszcie na samym zaokraglonym cyplu półwyspu umieszczono krótki napis: „Ictiophagi. Hos Alexander vetuit piscibus vesci” ${ }^{195}$. Drugi, paralelny pas tworzy trójkąt, w którego wnętrzu narysowano trzy skrzydlate istoty: u góry

${ }^{191}$ Por. tamże, s. 225 , ryc. 21 ; s. 227 , ryc. 24C; s. 331, tab. V/3.

${ }_{192}$ Tekst legendy za: Die Ebstorfer Weltkarte, Bd. I, s. 68 (20 A1/2). Por. Sommerbrodt, Die Ebstorfer Weltkarte, [Teil: Text], s. 65, 2-3; Miller, Mappaemundi. Die ältesten Weltkarten, V. Heft, s. 53. Komentarz: Die Ebstorfer Weltkarte, Bd. II, s. 122 (20/2).

${ }^{193}$ Tekst legendy za: Die Ebstorfer Weltkarte, Bd. I, s. 54 (13 B1/3). Por. Sommerbrodt, Die Ebstorfer Weltkarte, [Teil: Text], s. 65, 1; Miller, Mappaemundi. Die ältesten Weltkarten, V. Heft, s. 53. Komentarz: Die Ebstorfer Weltkarte, Bd. II, s. 101 (13/3).

${ }^{194}$ Tekst legendy za: Die Ebstorfer Weltkarte, Bd. I, s. 54 (13 A2/2). Por. Sommerbrodt, Die Ebstorfer Weltkarte, [Teil: Text], s. 64, 26-30; Miller, Mappaemundi. Die ältesten Weltkarten, V. Heft, s. 53. Komentarz: Die Ebstorfer Weltkarte, Bd. II, s. 101 (13/2).

195 Tekst legendy za: Die Ebstorfer Weltkarte, Bd. I, s. 54 (13 A2/1). Por. Sommerbrodt, Die Ebstorfer Weltkarte, [Teil: Text], s. 64, 25; Miller, Mappaemundi. Die ältesten Weltkarten, V. Heft, s. 60. Komentarz: Die Ebstorfer Weltkarte, Bd. II, s. 101 (13/1). 
jest to „Draco”, po jego lewej stronie siedzi mały „Basiliscus” a po prawej agresywny w stosunku do tego ostatniego „Aspis”"196. Pod wizerunkami tych ptasich hybryd, tuż nad pasmem górskim po jego wewnętrznej stronie, została dodana obszerna legenda: „Hec terra basiliscum creat id est malum in terris singulare, serpens est ad semipedis longitudinem, quasi metrulla alba. Movetur media corporis parte, altera parte arduus est et excelsus"197. Zespół legend i rysunków widniejący na mapie z Ebstorf podkreśla jednoznacznie (w swej warstwie literackiej) paralelizm pomiędzy Wrotami Kaspijskimi, czyli klauzurą północno-wschodniej Azji, a wrotami Nubijskimi, czyli klauzurą południowo-wschodniej Afryki. Jednak o ile Wrota Kaspijskie, broniące ekumeny przed tzw. wrogiem z Północy, są podobnie jak na mapie z Sawley tylko naturalnym górskim pasażem ${ }^{198}$, o tyle Wrota Nubijskie, chroniące zamkniętych za nimi chrześcijan przed atakiem islamskim od strony Egiptu, są masywną budowlą bramną wzniesioną przez biegłe w budownictwie ludy, które talentem tym obdarował, jak już wskazano wyżej, Duch Święty. Powraca zatem w formie graficznej topos tępoty umysłowej, będących we władzy szatana, ludów Północy ${ }^{199}$. Powraca jednak także logika wywodu przedstawionego już w kontekście mapy z Sawley. Odpowiada to oczywiście grosso modo sytuacji geopolitycznej panującej $\mathrm{w}$ tym regionie $\mathrm{w}$ czasie powstawania mapy. Koresponduje to również z klimatem społecznym, politycznym oraz z mentalnością dominującą w tym okresie na łacińskim, chrześcijańskim Zachodzie.

Z kolei mapa $\mathrm{z}$ Hereford (tab. XVIII/7 $=\mathrm{A}^{1 / 5}$ 55) posiada także dobrze widoczne pasmo górskie, oddzielające trójkątny półwysep od reszty Afryki. Góry te to jak głosi legenda „Montes Nibie”200, w które „wbudowano” silnie ufortyfikowane i szczelnie zamknięte „Portee Nibie”"201. Na prawo od tej legendy jest dłuższy napis: „Hic locus dicitur Moys[e]: id est, aque ortus”202,

196 Tekst legend za: Die Ebstorfer Weltkarte, Bd. I, s. 54 (13 B2/5-7). Por. Sommerbrodt, Die Ebstorfer Weltkarte, [Teil: Text], s. 65, 7; Miller, Mappaemundi. Die ältesten Weltkarten, V. Heft, s. 61. Komentarz: Die Ebstorfer Weltkarte, Bd. II, s. 101-102 (13/5: Draco), s. 102 (13/6: Aspis), s. 102 (13/7: Basiliscus).

${ }^{197}$ Tekst legendy za: Die Ebstorfer Weltkarte, Bd. I, s. 54 (13 B2/8). Por. Sommerbrodt, Die Ebstorfer Weltkarte, [Teil: Text], s. 65, 8-10; Miller, Mappaemundi. Die ältesten Weltkarten, V. Heft, s. 61. Komentarz: Die Ebstorfer Weltkarte, Bd. II, s. 102 (13/8).

${ }^{198}$ Por. Kochanek, Klauzura pótnocno-wschodniej Azji, s. 225, ryc. 22; s. 227, ryc. 24D; s. 330, tab. IV/4.

${ }^{199}$ Por. przyp. 188.

${ }^{200}$ Tekst legendy za: Westrem, The Hereford Map, s. 93 (nr 196). Por. Bevan - Phillott, Mediaeval Geography, s. 82; Miller, Mappaemundi. Die ältesten Weltkarten, IV. Heft, s. 40. Komentarz: Westrem, The Hereford Map, s. 92 (nr 196).

${ }^{201}$ Tekst legendy za: Westrem, The Hereford Map, s. 93 (nr 195). Por. Bevan - Phillott, Mediaeval Geography, s. 82; Miller, Mappaemundi. Die ältesten Weltkarten, IV. Heft, s. 40. Komentarz: Westrem, The Hereford Map, s. 92 (nr 195).

${ }^{202}$ Tekst legendy za: Westrem, The Hereford Map, s. 93 (nr 199). Por. Bevan - Phillott, Mediaeval Geography, s. 82; Miller, Mappaemundi. Die ältesten Weltkarten, IV. Heft, s. 39. Komentarz: Westrem, The Hereford Map, s. 92 (nr 199). 
a powyżej drugi, dotyczący źródeł Nilu - „Fialus, fons Nili”203. Bezpośrednio nad nim jest widoczna winieta miasta wraz z dookreśleniem: „Oppidum Nibie"204. Natomiast na prawo od niej znajduje się najistotniejszy tekst tej części mapy, który brzmi: „Nibei, gens Nibie Ethiopes Christianissimi” ${ }^{205}$. Wreszcie na samym cyplu półwyspu zlokalizowano winietę wysokiej góry zaopatrzonej w ogniste języki oraz tekst: „Mons Ardens” ${ }^{206}$. Południowo-wschodnia klauzura mapy z Hereford chroni zatem chrześcijańskich Etiopów przed agresją muzułmańskiego Egiptu. Jest to więc przedstawienie sytuacji geopolitycznej korespondującej z czasem powstania mapy. Jeśli zaś porównać klauzurę południowo-wschodniej Afryki z klauzurą północno-wschodniej Azji, to sytuacja jest tutaj analogiczna do tej, jaką przedstawił rysownik mapy z Psałterza Londyńskiego. Innymi słowy zarówno Wrota Kaspijskie jak i Wrota Nubijskie to warowne budowle bramne. Jednak Brama Nubijska z obronnego punktu widzenia wydaje się być zbudowana o wiele solidniej niż jej kaspijska odpowiedniczka. $Z$ kolei ta ostatnia posiada swego rodzaju naturalne wzmocnienie w postaci bardzo wąskiego wąwozu, czy wręcz jaru, który do niej prowadzi ${ }^{207}$. Innymi słowy nawet gdyby ludy Północy sforsowały bramę, to istnieje jeszcze teoretyczna możliwość powstrzymywania ich marszu w wąskim przejściu „termopilskim” między dwoma łańcuchami górskimi. Grafika mapy z Hereford zdaje się więc podkreślać równorzędność niebezpieczeństwa po obu stronach ekumenicznej osi symetrii. Porównując graficzne przedstawienie tego zagadnienia na mapie z Ebstorf i na mapie z Hereford można dojść do wniosku, że prezentują one dwa odmienne punkty widzenia na temat przedmiotowych klauzur. Pierwsza oddaje geopolityczną perspektywę niemiecką druga angielską.

${ }^{203}$ Tekst legendy za: Westrem, The Hereford Map, s. 91 (nr 194). Por. Bevan - Phillott, Mediaeval Geography, s. 82; Miller, Mappaemundi. Die ältesten Weltkarten, IV. Heft, s. 39. Komentarz: Westrem, The Hereford Map, s. 90 (nr 194).

${ }^{204}$ Tekst legendy za: Westrem, The Hereford Map, s. 91 (nr 193). Por. Bevan - Phillott, Mediaeval Geography, s. 82; Miller, Mappaemundi. Die ältesten Weltkarten, IV. Heft, s. 39. Komentarz: Westrem, The Hereford Map, s. 90 (nr 193).

${ }^{205}$ Tekst legendy za: Westrem, The Hereford Map, s. 93 (nr 198). Por. Bevan - Phillott, Mediaeval Geography, s. 82; Miller, Mappaemundi. Die ältesten Weltkarten, IV. Heft, s. 38. Komentarz: Westrem, The Hereford Map, s. 92 (nr 198).

${ }^{206}$ Tekst legendy za: Westrem, The Hereford Map, s. 91 (nr 192). Por. Bevan - Phillott, Mediaeval Geography, s. 82; Miller, Mappaemundi. Die ältesten Weltkarten, IV. Heft, s. 40. Komentarz: Westrem, The Hereford Map, s. 90 (nr 192).

${ }^{207}$ Por. Kochanek, Klauzura pótnocno-wschodniej Azji, s. 225, ryc. 23; s. 229, ryc. 25B; s. 331, tab. V/4. 
Tab. XVIII: Portae Nubiae

\begin{tabular}{|c|c|c|c|}
\hline 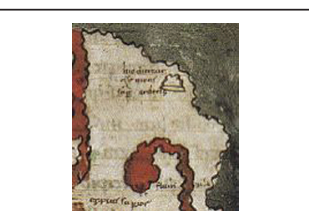 & (2) & 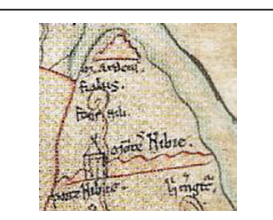 & 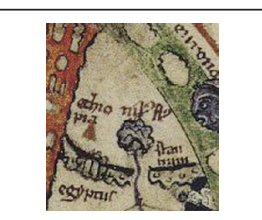 \\
\hline 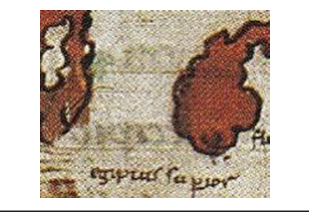 & 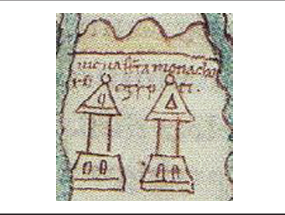 & Guresturte & 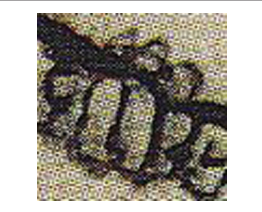 \\
\hline $\begin{array}{c}\text { 1. Cottoniana } \\
\text { (ok. 1030) }\left[\mathrm{A}^{1 / 15}\right]\end{array}$ & $\begin{array}{c}\text { 2. Wiktoryńska mapa } \\
\text { ekumeny (XI/XII w.) } \\
{\left[\mathrm{A}^{1} / 25\right]}\end{array}$ & $\begin{array}{l}\text { 3. Mapa z Sawley } \\
(1110 / 1180)\left[\mathrm{A}^{1 / 32}\right]\end{array}$ & $\begin{array}{c}\text { 4. Mapa z Psałterza } \\
\text { Londyńskiego (ok. } \\
\text { 1260) }\left[\mathrm{A}^{1 / 52}\right]\end{array}$ \\
\hline 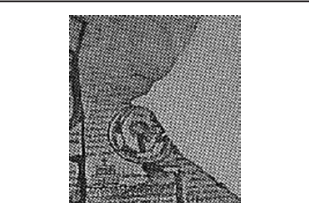 & and & & \\
\hline 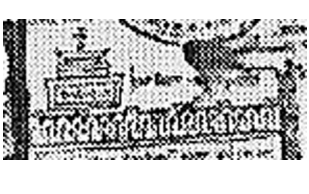 & (x) & If & \\
\hline $\begin{array}{l}\text { 5. Rotulus z Vercelli } \\
\left(\text { ok. 1270) }\left[\mathrm{A}^{1 / 53}\right]\right.\end{array}$ & $\begin{array}{l}\text { 6. Mapa z Ebstorf } \\
\text { (ok. 1300) }\left[\mathrm{A}^{1 / 54}\right]\end{array}$ & $\begin{array}{l}\text { 7. Mapa z Hereford } \\
(1276 / 1305)\left[\mathrm{A}^{1 / 55}\right]\end{array}$ & \\
\hline
\end{tabular}

Analiza porównawcza Wrót Kaspijskich z Wrotami Nubijskimi, przeprowadzona nawet $\mathrm{w}$ tak ograniczonym, jeśli chodzi o te drugie bramy, zakresie, prowadzi do bardzo ciekawych, jak widać, wniosków. Obie bramy rozpatrywane łącznie stanowią bowiem jeden z najbardziej newralgicznych z graficznego punktu widzenia elementów mapy średniowiecznej. To właśnie na ich podstawie da się w pewnym stopniu określić stosunek twórcy danej mapy do „ekumenicznych” problemów geopolitycznych swej epoki, ponieważ ta graficzna paralela daje możliwość pokazania dwóch równoległych rzeczywistości: klauzury północno-wschodniej Azji i enklawy południowo-wschodniej Afryki. Wykorzystując tę graficzną antytezę opartą na symetrii osiowej kartograf średniowieczny miał możliwość wprowadzenia widza na orbitę określonej polityczno-religijnej wizji świata. Nie jest to jednak obraz tzw. bliskiej zagranicy, lecz wizja peryferii. Jednak właśnie owa peryferyjność sprzyja pewnej graficznej wolności, czyli pozwala na jasną kategoryzację określonych zjawisk, bez obawy poniesienia konsekwencji, o co łatwo w przypadku graficznego komentowania stanu rzeczy w obrębie wspomnianej wyżej bliskiej 
zagranicy. Należy także zwrócić uwagę na trójkątny schemat enklawy południowo-wschodniej Afryki (tab. XVIII/2-4 i 7). Być może podobny kształt miała ta część ekumeny na Rotulusie z Vercelli (tab. XVIII/5 $=\mathrm{A}^{1 / 53}$ ) i na mapie $\mathrm{z}$ Ebstorf (tab. XVIII/6 = $\mathrm{A}^{1 / 54}$ ). Jednak stan zachowania tych map nie pozwala na jednoznaczne rozstrzygnięcie tej kwestii. Można natomiast stwierdzić, że obok Hiszpanii, Italii i Sycylii, również Etiopia na niektórych mapach średniowiecznych była „kodowana” w formie trójkąta.

$$
* * *
$$

Artykuł niniejszy pomyślany jako druga część rozprawki, która ukazała się w roku 2012 i dotyczyła schematów choro- i topograficznych w źródłach starożytnych ${ }^{208}$, miał za zadanie przedstawienie wpływu tej schematyzacji na zachowaną spuściznę kartograficzną średniowieczna i wczesnego okresu nowożytnego. Obiektywna ocena wyników obu tych prac pozostaje w gestii znawców przedmiotu. Natomiast w poniższych wnioskach końcowych należy wskazać na to, co zdaniem autora przedmiotowych prac stanowi o ich wartości. Za taką zaś wypada uznać już samo obszerne potraktowanie zagadnienia schematyzacji zarówno w geografii antycznej, jak i w kartografii średniowiecznej oraz wczesnonowożytnej. Schematyzacja ta miała trudny do przecenienia walor mnemotechniczny, a zatem służyła głównie szeroko rozumianej dydaktyce. W konsekwencji powstała cała seria toposów graficznych, odnoszących się do konkretnych regionów ekumeny. Ponieważ zaś toposy te odnosiły się do bardzo ograniczonej liczby enklaw, czyli w gruncie rzeczy funkcjonowały na marginesie chorografii jako takiej, zatem, jak można przypuszczać, terytoria objęte schematyzacją zaczęły cieszyć się w pewnym momencie szczególną sławą, gdyż ich schematy stały się niemal przysłowiowe. Mogło się to odnosić przede wszystkim do takich wysp jak Sycylia, widziana jako trójkąt, Sardynia zapamiętawana jako ludzka stopa, czy Cyklady (i Orkady), których regularny pierścień pozostawał w umysłach uczniów. Drugim niezwykle popularnym schematem chorograficznym była grecka litera „delta” zaaplikowana do kształtu ujścia niektórych rzek. Ponieważ zaś delta może być także traktowana jako trójkąt, a ten kształt nadawano także Etiopii, Hiszpanii i Italii, zatem można zasadnie domniemywać, że schemat trójkąta był na poziomie chorograficznym i chorometrycznym schematem bardzo popularnym. Przewyższał go pod tym względem tylko stosowany powszechnie na poziomie geografii i geometrii okrąg. Schemat okręgu funkcjonował zresztą również w ramach chorografii i chorometrii, chociażby w odniesieniu do przywołanego co dopiero archipelagu Cyklad i Orkad lub też w odniesieniu do pojedynczych wysp. Prawdopodobnie także dobrze znane i łatwo przyswajalne na poziomie dydaktyki szkolnej były schematy pasm górskich, którym nadawano niezwykle sugestywny kształt naturalnych wałów lub murów obronnych. Fortyfikacje te, które musiały jawić się współczesnym jako obronne dzieła Bożej opatrzności,

\footnotetext{
${ }^{208}$ Kochanek, Iluzja schematów choro- i topograficznych, passim.
} 
widniały w ściśle określonych sektorach map, tworząc klauzurę północnowschodniej Azji i symetryczną do niej klauzurę południowo-wschodniej Afryki. W Europie natomiast górskie obwarowania broniły Italii oraz Hiszpanii, a dokładniej Rzymu i Kompostelli. Mapa ekumeny tego okresu widziana przez pryzmat rozmieszczenia pasm górskich przypomina rodzaj militarnej szachownicy, gotowej do toczenia gier wojennych. Faktycznie jednak tak rozumiana mapa miała uzmysławiać swemu czytelnikowi geopolityczną hierarchię poszczególnych obszerów zamieszkałej ziemi.

Analizując zagadnienie zachowanych schematów kartograficznych należy jednak pamiętać, że zarówno z powodu szczupłości zachowanego dziedzictwa kartograficznego, jak również ze względu na niewielkie rozmiary większości ocalałych map bardzo wiele schematów stosowanych w geografii starożytnej musiało niejako siła rzeczy zostać w okresie średniowiecza zapomnianych. Obok ograniczeń, rzec by można, technicznych, przyczynił się do tego również fakt, że bez wątpienia wielu popularnych w dobie antyku schematów nie odnotowali w swych dziełach wielcy encyklopedyści wieków średnich. Inne natomiast, takie jak np. schemat buta włoskiego, zrobiły karierę dopiero nieco później, w zmienionym klimacie geopolitycznym okresu nowożytnego. Podstawą selekcji zastanych schematów starożytnych był dla średniowiecznych ludzi pióra światopogląd chrześcijański, oparty na autorytecie Biblii. To zgodnie z przesłaniem tej Księgi została m.in. odczytana rola łańcuchów górskich w strukturze ekumeny.

Tymczasem w opinii starożytnych za żywioł szczególnie, rzec by można, schematotwórczy uchodziło morze, decydujące o kształcie linii brzegowej oraz o rozmieszczeniu wysp, co podkreślał Strabon ${ }^{209}$, powtarzając zapewne grecki z pokolenia na pokolenie przekazywany pogląd, który dobrze oddaje mentalność narodu żeglarzy. Na tej podstawie można założyć, że w równej mierze starożytność jak i średniowiecze, zarówno zachodnie jak i bizantyńskie, wytworzyły ogromną ilość przeróżnych schematów na użytek lokalnej żeglugi, czyli lokalnej mnemotechniki żeglarskiej, która ułatwiała naukę trudnej sztuki nawigacji. Nie należy się zatem dziwić, że większość schematów przekazanych przez kartografów omawianego tutaj okresu odnosi się w ten czy inny sposób do morza jako takiego. Na drugim miejsce pod tym względem należy umieścić góry, a następnie rzeki. Mapy poprzez toposy graficzne „rozsławiały” pewne regiony i powodowały, że ich wizualna „znajomość” była niewątpliwie znacznie szersza niż ich rzeczywista rola oraz realny wkład ich mieszkańców w dzieje i w rozwój kultury śródziemnomorskiej czy europejskiej. Na tym też w dużej mierze polegało zapewne znaczenie toposu chorograficznego i topograficznego. Kwestią otwarta pozostaje natomiast pytanie, czy topos ten był używany świadomie w tym właśnie celu. Innymi słowy, czy na nim opierano w jakiejś mierze ówczesną propagandę geopolityczną, dzięki której narody

\footnotetext{
${ }^{209}$ Por. przyp. 9.
} 
basenu Morza Śródziemnego starały się podtrzymywać ideę swej iluzorycznej już wówczas wyższości nad narodami północnej części Europy.

Z kolei patrząc na topos graficzny jako na swego rodzaju odbicie toposu literackiego można ów wspomniany wyżej selektywny dobór starożytnych schematów chorograficznych i topograficznych przez twórców map średniowiecznych i wczesnonowożytnych uzasadniać na gruncie zawartości źródeł literackich. Antyczne bowiem źródła, szczególnie greckie, które zawierały analizowane tutaj schematy nie były przecież zachodnim kartografom średniowiecznym znane wprost. Funkcję pośredników pełniły wspomniane dopiero co dzieła o charakterze encyklopedycznym, które powstały w dobie cesarstwa rzymskiego (Pomponiusz Mela, Pliniusz, Tacyt, Ammianus Marcellinus) oraz we wczesnym średniowieczu. W tym ostatnim okresie ich twórcami były wielkie dla późniejszego okresu autorytety m.in. w zakresie geografii, takie jak Solinus, Orozjusz, Makrobiusz, Marcjanus Kapella, Izydor z Sewilli, czy Raban Maur. To oni byli swego rodzaju pasami transmisyjnymi między (grecką) geografią starożytną a kartografią łacińskiego średniowiecza, o czym świadczą najlepiej legendy, które zawierają mappaemundi tego okresu. To głównie dzięki nim topos literacki stał się także toposem graficznym, mającym szansę trafienia do szerszego grona odbiorców. O takich gronie można jednak zasadnie mówić tylko w kontekście wielkich map, takich jak np. mapa z Ebstorf [A ${ }^{1 / 54}$ ], czy mapa z Hereford [ $\mathrm{A}^{1 / 55}$, które najprawdopodobniej już z założenia były dostępne szerszej, czy wręcz szerokiej publiczności.

Powyższe analizy ukazują z jednej strony żywotność pewnych toposów geo-, choro- i topograficznych, z drugiej zaś akcentują ich selektywny dobór. Selekcja ta prowadzi do powstania wąskiej grupy graficznych toposów wiodących, które przetrwały wiele wieków. Jednak ostatecznie i one musiały odejść w niebyt z chwilą, gdy kartografia przestała opierać się na autorytecie pochodzącym $z$ tradycji literackiej, a zaczęła bazować na autorytecie, którego źródłem stało się realne doświadczenie, głównie żeglarskie, choć ograniczone w analizowanym tutaj okresie do basenu Morza Śródziemnego. Eliminowanie antycznych toposów usuwało jednocześnie w cień biblijny teologiczno-teleologiczny obraz świata, któremu służyły, oraz związany z nim typ mnemotechniki. W centrum tego modelu stał Krzyż Chrystusa, wspierany przez Pawłowa typologię Adam-Chrystus i wprzęgnięte w orientację ramion Krzyża kierunki kardynalne. W ten sposób każda mapa była swego rodzaju chrystogramem. $Z$ tym nadrzędnym schematem były w pewien sposób skonfigurowane wszystkie inne schematy mapy, oparte głównie na głęboko symbolicznych figurach „doskonałych”, czyli na kole, prostokącie (kwadracie) i trójkącie. To te właśnie schematy złożyły się na ową wąską grupę graficznych toposów wiodących i najdłużej opierały się nowemu obrazowi świata.

Na koniec warto raz jeszcze wrócić do dwóch terminów wyeksponowanych w punkcie wyjścia niniejszych rozważań, a mianowicie do schematyza-

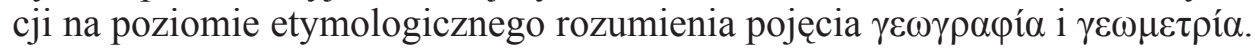


W szerokim znaczeniu przetrwały one fazę zaniku schematyzacji choro- i topograficznej, jednak zmieniło się diametralnie pojmowanie tych terminów jako takich. Przestały bowiem być dwoma aspektami refleksji intelektualnej nad Ziemia, czyli odnosić się do opisu i pomiaru naszej planety, jak tego chce ich etymologia, a stały się osobnymi dyscyplinami naukowymi. W ten sposób zaczęły one żyć własnym życiem, choć geografia stale potrzebuje geometrii, podkreślając tym samym (niekoniecznie świadomie) łączące je od zarania ich językowej egzystencji ,więzy krwi”.

\section{Aneks I}

\section{„Metryki” map wykorzystanych w artykule 210}

[1] Watykańska mapa Izydora. • Źródło oryginału: Watykan, Biblioteca Apostolica Vaticana, Ms Vat. Lat. 6018, fol. 64 ${ }^{\mathrm{v}}-65^{\mathrm{r}}$ (wielkość oryginału: 290 x $220 \mathrm{~mm}$; data powstania: ok. 775). Por. Uhden, Die Weltkarte des Isidorus von Sevilla, s. 2; Destombes, Mappemondes A.D. 1200-1500, s. 30 (1,7); Brincken, Fines Terrae, s. XVI (9) i s. 49-50; English, Ordo orbis terrae, s. 569; Chekin, Northern Eurasia in Medieval Cartography, s. 126-128 (X.1.). • Tekst legend mapy: Uhden, Die Weltkarte des Isidorus von Sevilla, s. 25-28; G. Menéndez-Pidal, Mozárabes y Asturianos en la cultura de la alta Edad Media en relación especial con la historia de los conocimientos geográficos, „Boletin de la Real Academia de la Historia” 134 (1954) 188 (legendy znajdują się na przerysie mapy); Glorie, Mappa mundi (e codice Vatic. Lat. 6018), s. 456-466; J. Williams, Isidore, Orosius and the Beatus Map, „Imago Mundi" 49 (1997) 16, rys. 6 (kopia przerysu G. Menéndez-Pidala); English, Ordo orbis terrae, s. 568 (kopia przerysu G. Menéndez-Pidala). • Fragmenty tekstu legend mapy: Chekin, Northern Eurasia in Medieval Cartography, s. 128 (X.1.). • Źródło kopii: Englisch, Ordo orbis terrae, s. 130, rys. 18. Por. Chekin, Northern Eurasia in Medieval Cartography, s. 447 (X.1.); A. Scafi, Maps of Paradise, London 2013, 47, rys. 24.

${ }^{210}$ Niniejszy aneks jest chronologicznym zestawieniem „metryk” map, które posłużyły jako źródła w powyższych analizach i z których pochodzą wycinki map zawarte w prezentowanych zestawieniach tabelarycznych (tab. I-XVIII). „Metryki” mają następującą strukturę: 1. nazwa mapy; 2. miejsce jej przechowywanie, określone tutaj mianem ,źródło oryginału” (wraz z danymi dotyczącymi wielkość tegoż oryginału i czasu jego powstania, podanymi w nawiasie). Jeśli zaś istnieją już podobne „metryki”, wykonane przez innych autorów, to są one cytowane na zasadzie „por.” bezpośrednio po wspomnianym wyżej nawiasie; 3 . dane na temat publikacji znajdujących się na mapie legend, które otwiera formuła: „tekst legend mapy” i „fragmenty tekstu legend mapy”; 4. wydanie z którego pochodzi skan prezentowanego w tabelach elementu mapy = „źródło kopii”. Jeśli mapa jest stosunkowo rzadko reprodukowana lub jej kopie są dobre technicznie, wówczas obok właściwego „źródła kopii” są cytowane na zasadzie „por.” inne wydania danej mapy. W tym ostatnim przypadku chodzi przede wszystkim o wydania reprodukcji map w dużym formacie i w kolorze. Jeśli któryś w czterech wyliczonych elementów nie występuje w „metryce” danej mapy (chodzi głównie o „tekst legend mapy” i „fragmenty tekstu legend mapy”), oznacza to, że dane takie nie istnieją (lub nie są znane niżej podpisanemu). 
[2] Mapa z Albi (IX w.). • Źródło oryginału: Albi, Bibliothèque municipale, Ms 29, fol. 487 (wielkość oryginału: 290 x $230 \mathrm{~mm}$; data powstania: IX w.). Por. Destombes, Mappemondes A.D. 1200-1500, s. 46 (22,1); A.H. Sijmons - H. Wallis, Atlas de Santarem. Fascimile of the final edition 1849. Explanatory notes, Amsterdam 1985, 49 (plate 4, nr 1); Brincken, Fines Terrae, s. XVIII (27); Chekin, Northern Eurasia in Medieval Cartography, s. 93-94 (VII.1.). - Tekst legend mapy: Santarem, Essai sur l'histoire de la cosmographie, t. 2, s. 26-31; Miller, Mappaemundi. Die ältesten Weltkarten, III. Heft, s. 58-59; F. Glorie, Mappa mundi e codice Albigensi 29, w: Itineraria et alia geographica, CCL 175, Turnholti 1965, 469; Chekin, Northern Eurasia in Medieval Cartography, s. 94-95 (VII.1.). • Źródło kopii: Chekin, Northern Eurasia in Medieval Cartography, s. 394 (VII.1.).

[3] Mapa z „The Morgan Beatus”. • Źródło oryginału: Nowy Jork, Pierpont Morgan Library, Ms 644, fol. 33 ${ }^{\mathrm{v}}-34^{\mathrm{r}}$ (wielkość oryginału: 530 x $380 \mathrm{~mm}$; data powstania: 940-945). Por. Destombes, Mappemondes A.D. 1200-1500, s. 40 (17,1); Brincken, Fines Terrae, s. XVIII (20) i s. 56-58; English, Ordo orbis terrae, s. 593; Chekin, Northern Eurasia in Medieval Cartography, s. 172 (XI.1.1.). • Tekst legend mapy: K. Miller, Mappaemundi. Die ältesten Weltkarten, I. Heft: Die Weltkarte des Beatus (776 n. Chr.), Stuttgart 1895, 37 38; Menéndez-Pidal, Mozárabes y Asturianos, s. 235 (legendy znajdują się na przerysie mapy); H. García-Aráez, Los mapamundis de los Beatos (2 $2^{\mathrm{a}}$ parte). Nomenclator y conclusiones, „Miscelánea Medieval Murciana” 19-20 (19951996) 100-123; English, Ordo orbis terrae, s. 592 (kopia przerysu G. Menéndez-Pidala). • Zródło kopii: I. Baumgärtner, Graphische Gestalt und Signifikanz. Europa in den Weltkarten des Beatus von Liébana und des Ranulf Hidgen, w: Europa im Weltbild des Mittelalters. Kartographische Konzepte, hrsg. von I. Baumgärtner und H. Kugler, Orbis Mediaevalis 10, Berlin 2008, 90, rys. 4. Por. English, Ordo orbis terrae, s. 261, rys. 41.

[4] Mapa z San Millán de la Cogolla. • Źródło oryginału: Madryt, Real Academia, Ms 25, fol. 204v (średnica oryginału: $190 \mathrm{~mm}$; data powstania: 946). Por. Destombes, Mappemondes A.D. 1200-1500, s. 31 (3,8); Brincken, Fines Terrae, s. XVII (13) i s. 51; Chekin, Northern Eurasia in Medieval Cartography, s. 79 (IV.2.2.). • Tekst legend mapy: Menéndez-Pidal, Mozárabes y Asturianos, s. 184 (legendy znajdują się na przerysie mapy. De facto legendy te zostały naniesione na „Mapę z Cardeña”. Jednak „Mapa z San Millán de la Cogolla" jest jej wierną kopia). • Źródło kopii: Chekin, Northern Eurasia in Medieval Cartography, s. 383 (IV.2.2.)

[5] Mapa z Cardeña. • Źródło oryginału: Madryt, Real Academia, Ms 76, fol. $108^{\mathrm{r}}$ (średnica oryginału: $104 \mathrm{~mm}$ : data powstania: X w.). Por. Destombes, Mappemondes A.D. 1200-1500, s. 32 (3,9); Brincken, Fines Terrae, s. XVII (12) - Autorka nazywa ją mylnie „Ökumene-Karte aus San Millán de la Cogolla" - i s. 51; por. tamże, tab. 8; P. Gautier Dalché, De la glose 
à la contemplation. Place et fonction de la carte dans les manuscrits du haut Moyen Âge, w: Testo e imagine nell'Alto Medioevo, 15-21 aprile 1993, t. 2, Settimane di Studio del Centro Italiano di Studi sull'Alto Medioevo 41/2, Spoleto 1994, 725-726 i przyp. 82; Chekin, Northern Eurasia in Medieval Cartography, s. 79 (IV.2.1.). • Tekst legend mapy: Menéndez-Pidal, Mozárabes y Asturianos, s. 184 (legendy znajdują się na przerysie mapy); Williams, Isidore, Orosius and the Beatus Map, s. 14, rys. 5 (kopia przerysu G. MenéndezPidala). • Źródło kopii: http://litteravisigothica.com/codex-of-the-month-viiimadrid-real-academia-de-la-historia-cod-76/ [data dostępu: 14 IX 2017]. Por. Menéndez-Pidal, Mozárabes y Asturianos, s. 184; Chekin, Northern Eurasia in Medieval Cartography, s. 382 (IV.2.1.)

[6] Mapa Beatusa z Valladolid. • Źródło oryginału: Valladolid, Biblioteca de la Universidad, Ms 433, fol. 36 $-37^{\mathrm{r}}$ (wielkość oryginału: 450 x $310 \mathrm{~mm}$; data powstania: 970). Por. Destombes, Mappemondes A.D. 1200-1500, s. 40 (17,3); English, Ordo orbis terrae, s. 581; Chekin, Northern Eurasia in Medieval Cartography, s. 172 (XI.1.3.). • Tekst legend mapy: Miller, Mappaemundi. Die ältesten Weltkarten, I. Heft, s. 37-38; Menéndez-Pidal, Mozárabes y Asturianos, s. 236 (legendy znajdują się na przerysie mapy); García-Aráez, Los mapamundis de los Beatos (2 ${ }^{\text {a }}$ parte), s. 100-123; English, Ordo orbis terrae, s. 580 (kopia przerysu G. Menéndez-Pidala). • Źródło kopii: English, Ordo orbis terrae, s. 221, rys. 34.

[7] Mapa Beatusa z Gerony. • Źródło oryginału: Gerona, Museu de la Catedral de Girona, nr inv. 7 (11), fol. $54^{\mathrm{v}}-55^{\mathrm{r}}$ (wielkość oryginału: 520 x $350 \mathrm{~mm}$; data powstania: 975). Por. Destombes, Mappemondes A.D. 1200-1500, s. 41 (17,5); English, Ordo orbis terrae, s. 601; Chekin, Northern Eurasia in Medieval Cartography, s. 174 (XI.2.1.). • Tekst legend mapy: Miller, Mappaemundi. Die ältesten Weltkarten, I. Heft, s. 38-41; Menéndez-Pidal, Mozárabes y Asturianos, s. 247 (legendy znajdują się na przerysie mapy); García-Aráez, Los mapamundis de los Beatos (2a parte), s. 100-123; English, Ordo orbis terrae, s. 600 (kopia przerysu G. Menéndez-Pidala). • Źródło kopii: English, Ordo orbis terrae, s. 287, rys. 47. Por. C. Sánchez-Albornoz, La España christiana de los siglos VIII al. XI, vol. 1: El reino Astur-Leonés (722-1037): Sociedad, economía, gobierno, cultura y vida, Historia de España 7/1, Madrid 1980, 617.

[8] Mapa Beatusa z Seu de Urgell. • Źródło oryginału: Seu de Urgell, Museu Diocesá, nr inv. 501, fol. VI ${ }^{\mathrm{v}}-\mathrm{VII}^{\mathrm{r}}$ (wielkość folium oryginału: 400 x $265 \mathrm{~mm}$; data powstania: koniec X w.). Por. Destombes, Mappemondes A.D. 1200-1500, s. 40 (17,2); English, Ordo orbis terrae, s. 597; Chekin, Northern Eurasia in Medieval Cartography, s. 172 (XI.1.2.). • Tekst legend mapy: Menéndez-Pidal, Mozárabes y Asturianos, s. 237 (legendy znajdują się na przerysie mapy); García-Aráez, Los mapamundis de los Beatos (2a parte), s. 100123; English, Ordo orbis terrae, s. 596 (kopia przerysu G. Menéndez-Pidala). - Źródło kopii: English, Ordo orbis terrae, s. 275, rys. 44. 
[9] „Berlińska” mapa Makrobiusza. • Źródło oryginału: Berlin Staatsbibliothek zu Berlin, Preußischer Kulturbesitz, Cod. Phillipps 1833 (Cat. no. 138), fol. $39^{\mathrm{v}}$ (średnica oryginału: $170 \mathrm{~mm}$; data powstania: X/XI w.). Por. Destombes, Mappemondes A.D. 1200-1500, s. 46 (23,1); Chekin, Northern Eurasia in Medieval Cartography, s. 105 (VII.3.1.). • Tekst legend mapy: P. Gautier Dalché, Mappemonde dessinée à Fleury, w: Autour de Gerbert d'Aurillac le pape de l'an mil. Album de documents commentés, réunis sous la direction d'O. Guyotjeannin et M. Poulle, Matériaux pour l'Histoire publiés par École des Chartes 1, Paris 1996, s. 3-4 (tekst ten przedrukowano z minimalnymi zmianami w: P. Gautier Dalché, La Terre dans le cosmos, w: La Terre. Connaissance, représentations, mesure au Moyen Âge, sous la dir. de P. Gautier Dalché, L'Atelier du Médiéviste 13, Turnhout 2013, s. 198 i 200). - Fragmenty tekstu legend mapy: Chekin, Northern Eurasia in Medieval Cartography, s. 105-106 (VII.3.1.). • Źródło kopii: Chekin, Northern Eurasia in Medieval Cartography, s. 423 (VII.3.1.). Por. Gautier Dalché, De la glose à la contemplation, tablica XII; tenże, Mappemonde dessinée à Fleury, s. 2; tenże, La Terre dans le cosmos, s. 199.

[10] „Bamberska” mapa Makrobiusza. • Źródło oryginału: Bamberg, Staatsbibliothek, Ms Class. 38 (M-IV-15), fol. 20 (średnica oryginału: 175 mm; data powstania: X/XI w.). Por. Destombes, Mappemondes A.D. 12001500, s. 43 (20,1); Chekin, Northern Eurasia in Medieval Cartography, s. 97 (VII.2.5.); A. Hiatt, The Map of Macrobius before 1100, „Imago Mundi” 59 (2008) nr 2, 171 (5). • Tekst legend mapy: Hiatt, The Map of Macrobius before 1100, s. 173-175. • Źródło kopii: Chekin, Northern Eurasia in Medieval Cartography, s. 398 (VII.2.5.). Por. Hiatt, The Map of Macrobius before 1100, s. 157 , rys. 5 .

[11] „Oksfordzka” mapa Makrobiusza I. • Źródło oryginału: Oksford, Bodleian Library, Ms d'Orville 77, fol. 100 (średnica oryginału: $120 \mathrm{~mm}$; data powstania: X/XI w.). Por. Destombes, Mappemondes A.D. 1200-1500, s. 44 (20,12); Brincken, Fines Terrae, s. XVI (6); Chekin, Northern Eurasia in Medieval Cartography, s. 97-98 (VII.2.6.); Hiatt, The Map of Macrobius before 1100, s. 171 (16). • Tekst legend mapy: Hiatt, The Map of Macrobius before 1100, s. 173-175. • Źródło kopii: Chekin, Northern Eurasia in Medieval Cartography, s. 399 (VII.2.6.). Por. A.-D. von den Brincken, Kartographische Quellen Welt-, See- und Regionalkarten, Typologie des Sources du Moyen Âge Occidental 51, Turnhout 1988, tab. 1; taż, Fines Terrae, tab. 6; Edson - Savage-Smith, Medieval Views of the Cosmos, s. 52, rys. 27; Hiatt, The Map of Macrobius before 1100, s. 158, rys. 6; Edson - Savage-Smith - Brincken, Der mittelalterliche Kosmos, s. 46, rys. 32.

[12] „Petersburska” mapa Makrobiusza. • Źródło oryginału: Petersburg, Российская Национальная Библиотека, Ms Lat. Q.v.XVII, no. 3, fol. 1 ${ }^{\text {r }}$ (średnica oryginału: $178 \mathrm{~mm}$; data powstania: X/XI w.). Por. Chekin, Northern 
WPEYW STAROŻYTNEJ SCHEMATYZACJI MNEMOTECHNICZNEJ NA KARTOGRAFIE 347

Eurasia in Medieval Cartography, s. 98-99 (VII.2.8.); Hiatt, The Map of Macrobius before 1100, s. 171 (13). • Tekst legend mapy: Б.Я. Рамм, Новонайденный ленинградский экземпляр макробиевой карты и его научное значение, „Ученые Записки Ленинградского Государственного Университета", Серия Исторических Наук 18 (1951) nr 130, 250-270; Hiatt, The Map of Macrobius before 1100, s. 173-175. • Źródło kopii: Chekin, Northern Eurasia in Medieval Cartography, s. 401 (VII.2.8.).

[13] Mapa Makrobiusza z Troyes. • Źródło oryginału: Troyes, Bibliothèque municipal, Ms 804, fol. 233 (średnica oryginału: $125 \mathrm{~mm}$; data powstania: X/XI w.). Por. Destombes, Mappemondes A.D. 1200-1500, s. 43 (19,3); Chekin, Northern Eurasia in Medieval Cartography, s. 99 (VII.2.11.); Hiatt, The Map of Macrobius before 1100, s. 171 (26). • Tekst legend mapy: Hiatt, The Map of Macrobius before 1100, s. 173-175. • Źródło kopii: Chekin, Northern Eurasia in Medieval Cartography, s. 404 (VII.2.11.).

[14] Mapa Oksfordzka (1110), por. przyp. 31 i 37 oraz rys. 9.

[15] Cottoniana. • Źródło oryginału: Londyn, British Library, Ms Cotton Tiberius B. V., fol. $56^{v}$ (wielkość oryginału: 210 x $170 \mathrm{~mm}$; data powstania: ok. 1030). Por. Destombes, Mappemondes A.D. 1200-1500, s. 47 (24,6); Sijmons - Wallis, Atlas de Santarem, s. 54 (plate 8, nr 2); Brincken, Fines Terrae, s. XIX (28) i s. 60-62; English, Ordo orbis terrae, s. 589; Chekin, Northern Eurasia in Medieval Cartography, s. 129-130 (X.2.). • Tekst legend mapy: Santarem, Essai sur l'histoire de la cosmographie, t. 2, s. 50-76; Cortambert, Quelquesuns des plus anciens monuments géographique du Moyen Âge, s. 356-362; Miller, Mappaemundi. Die ältesten Weltkarten, III. Heft, s. 31-35. • Fragmenty tekstu legend mapy: Chekin, Northern Eurasia in Medieval Cartography, s. 131 (X.2.). • Źródło kopii: S. Foxell, Mapping England, London 2008, 26. Por. Brincken, Studien zur Universalkartographie des Mittelalters, tab. 16; Atlas. The Bulgarian Lands in the European Cartographic Tradition $\left(3^{r d}-19^{\text {th }}\right.$ Centuries), editors: A. Fol, A. Stamatov, Sofia 2008, 45 (I.2); Gautier Dalché, La Géographie de Ptolémée, s. 408, rys. II.

[16] Mapa z Escorialu. • Źródło oryginału: El Escorial, Biblioteca San Lorenzo, Ms Lat. et-1-3., fol. $177^{\mathrm{v}}$ (średnica oryginału: $136 \mathrm{~mm}$; data powstania: 1047). Por. Destombes, Mappemondes A.D. 1200-1500, s. 32 (4,3); Chekin, Northern Eurasia in Medieval Cartography, s. 80 (IV.2.3.). • Tekst legend mapy: Chekin, Northern Eurasia in Medieval Cartography, s. 80 (IV.2.3.). • Źródło kopii: Chekin, Northern Eurasia in Medieval Cartography, s. 384 (IV.2.3.).

[17] Mapa z „Facundus Beatus”. • Źródło oryginału:Madryt, Biblioteca Nacional, Vitrina 14-2 (dawniej: B. 31), fol. $63^{\mathrm{v}}-64^{\mathrm{r}}$ (wielkość oryginału: 470 x $310 \mathrm{~mm}$; data powstania: 1047). Por. Destombes, Mappemondes A.D. 12001500, s. 41 (17,6); English, Ordo orbis terrae, s. 573; Chekin, Northern Eurasia in Medieval Cartography, s. 173 (XI.1.4.). • Tekst legend mapy: Miller, 
Mappaemundi. Die ältesten Weltkarten, I. Heft, s. 37-38; Menéndez-Pidal, Mozárabes y Asturianos, s. 238 (legendy znajdują się na przerysie mapy); García-Aráez, Los mapamundis de los Beatos (2ª parte), s. 100-123; English, Ordo orbis terrae, s. 572 (kopia przerysu G. Menéndez-Pidala). • Źródło kopii: English, Ordo orbis terrae, s. 196, rys. 28. Por. Chekin, Northern Eurasia in Medieval Cartography, s. 470 (XI.1.4.) - niestety reprodukcja jest „odwrócona”.

[18] Beatus z Saint-Séver. • Źródło oryginału: Paryż, Bibliothèque Nationale, Ms Lat. 8878 (S. Lat. 1075), fol. 45 bis v $^{\mathrm{v}} 45$ ter $^{\mathrm{r}}$ (wielkość oryginału: 570 x $370 \mathrm{~mm}$; data powstania: 1047-1072). Por. Destombes, Mappemondes A.D. 1200-1500, s. 41 (17,7); Brincken, Fines Terrae, s. XVIII (21) i s. 56-58; Chekin, Northern Eurasia in Medieval Cartography, s. 177 (XI.4.). • Tekst legend mapy: Cortambert, Quelques-uns des plus anciens monuments géographique du Moyen Âge, s. 346-355; Miller, Mappaemundi. Die ältesten Weltkarten, I. Heft, s. 41-61; Menéndez-Pidal, Mozárabes y Asturiano, s. 254 (legendy znajdują się na przerysie mapy); García-Aráez, Los mapamundis de los Beatos (2a parte), s. 100-123; P. Gautier Dalché, Mappae mundi antérieures au

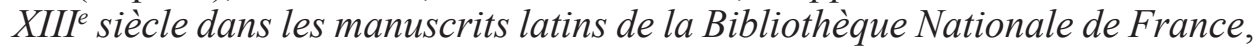
„Scriptorium” 52 (1998) 135-139 (nr 53); English, Ordo orbis terrae, s. 628 (kopia przerysu G. Menéndez-Pidala). • Fragmenty tekstu legend mapy: Chekin, Northern Eurasia in Medieval Cartography, s. 177-178 (XI.4.). • Źródło kopii: Miller, Mappaemundi. Die ältesten Weltkarten, I. Heft (mapa dołączona do tego tomu). Por. Baumgärtner, Graphische Gestalt und Signifikanz, s. 98, rys. 8; J.A. Wendt, Skarby kartografii, red. naukowa L. Szaniawska, Warszawa 2013, 50-51.

[19] Mapa z Ripoll. • Źródło oryginału: Watykan, Biblioteka Apostolica Vaticana, Ms Vat. Reg. Lat. 123, fol. $143^{\mathrm{v}}-144^{\mathrm{r}}$ (średnica oryginału: $338 \mathrm{~mm}$; data powstania: ok. 1055). Por. Destombes, Mappemondes A.D. 1200-1500, s. 48 (24,11); Brincken, Fines Terrae, s. XVIII (26) i s. 58-60; English, Ordo orbis terrae, s. 585; Chekin, Northern Eurasia in Medieval Cartography, s. 181182 (XII.1.). • Tekst legend mapy: A. Vidier, La mappemonde de Théodulf et la mappemonde de Ripoll (IXe-XIe siècle), „Bulletin de Géographie Historique et Descriptive” 26 (1911) 295-304; P. Gautier Dalché, Notes sur la „,carte de Théodose II” et sur la „,mappemonde de Théodulfe d 'Orléans”, „Geographia Antiqua" 3 (1994-1995) 91-108. • Fragmenty tekstu legend mapy: Chekin, Northern Eurasia in Medieval Cartography, s. 182-183 (XII.1.). • Zródło kopii: Chekin, Northern Eurasia in Medieval Cartography, s. 478 (XII.1.). Por. Gautier Dalché, Notes sur la „carte de Théodose II”, s. 106-107; Englisch, Ordo orbis terrae, s. 226, rys. 35.

[20] Beatus z Burgo de Osma. • Źródło oryginału: Burgo de Osma, Archivo de la Catedral, Ms 1, fol. $34^{\mathrm{v}}-35^{\mathrm{r}}$ (wielkość oryginału: 300 x $380 \mathrm{~mm}$; data powstania: 1086). Por. Destombes, Mappemondes A.D. 1200-1500, s. 41 $(17,8)$; Brincken, Fines Terrae, s. XVIII (22) i s. 56-58; English, Ordo orbis 
terrae, s. 625; Chekin, Northern Eurasia in Medieval Cartography, s. 176 (XI.3.1.). • Tekst legend mapy: Miller, Mappaemundi. Die ältesten Weltkarten, I. Heft, s. 34-36; Menéndez-Pidal, Mozárabes y Asturianos, s. 258 (legendy znajdują się na przerysie mapy); García-Aráez, Los mapamundis de los Beatos (2 ${ }^{\mathrm{a}}$ parte), s. 100-123. • Zródło kopii: English, Ordo orbis terrae, s. 345, rys. 61. Por. Baumgärtner, Graphische Gestalt und Signifikanz, s. 87, rys. 2; Scafi, Maps of Paradise, s. 48, rys. 25.

[21] Mapa Makrobiusza z Fryzyngi. • Źródło oryginału: Monachium, Bayerische Staatsbibliothek, Ms CLM 6362, fol. 74 (średnica oryginału: 149 mm; data powstania: XI w.). Por. Destombes, Mappemondes A.D. 1200-1500, s. $43(20,6)$; Brincken, Fines Terrae, s. XVI (5); Chekin, Northern Eurasia in Medieval Cartography, s. 132 (X.3.); Hiatt, The Map of Macrobius before 1100, s. 171 (23). • Tekst legend mapy: A.-D. von den Brincken, Romazentrische Weltdarstellung um die erste Jahrtausendwende, w: Kaiserin Theophanu: Begegnung des Ostens und Westens um die Wende des ersten Jahrtausends. Gedenkschrift des Kölner Schnütgen-Museums zum 1000. Todesjahr der Kaiserin, hrsg. von A. von Euw und P. Schreiner, Bd. 1, Köln 1991, 405; Hiatt, The Map of Macrobius before 1100, s. 173-175. • Fragmenty tekstu legend mapy: Chekin, Northern Eurasia in Medieval Cartography, s. 132 (X.3.). • Źródło kopii: Edson - Savage-Smith - Brincken, Der mittelalterliche Kosmos, s. 60, rys. 43. Por. Brincken, Fines Terrae, tab. 5; taż, Mappe del Medio Evo: Mappe del cielo e della terra, w: Cieli e terre nei secoli XI-XII. Orizzonti, percezioni, rapporti, Atti della tredicesima Settimana internazionale di studi, Mendola, 22-26 agosto 1995, Miscellanea del Centro di Studi Medioevali 15, Milano 1998, tab. V; taż, Studien zur Universalkartographie des Mittelalters, tab. 11; Chekin, Northern Eurasia in Medieval Cartography, s. 449 (X.3.); Hiatt, The Map of Macrobius before 1100, s. 161, rys. 8.

[22] „Paryska” mapa Makrobiusza I. • Źródło oryginału: Paryż, Bibliothèque Nationale, Ms Lat. 6371 (Reg. 5058.2), fol. 20v (średnica oryginału: $177 \mathrm{~mm}$; data powstania: XI w.). Por. Destombes, Mappemondes A.D. 12001500, s. 44 (20,13); Chekin, Northern Eurasia in Medieval Cartography, s. 98 (VII.2.7.); Hiatt, The Map of Macrobius before 1100, s. 171 (25). • Tekst legend mapy: Gautier Dalché, Mappae mundi antérieures au XIII ${ }^{e}$ siècle, s. 121122 (nr 18); Hiatt, The Map of Macrobius before 1100, s. 173-175. • Źródło kopii: Chekin, Northern Eurasia in Medieval Cartography, s. 400 (VII.2.7.).

[23] Mapa Makrobiusza z Dijon. • Źródło oryginału: Dijon, Bibliothèque municipale, Ms 448, fol. $76^{\mathrm{r}}$ (średnica oryginału: $168 \mathrm{~mm}$; data powstania: XI w.). Por. Destombes, Mappemondes A.D. 1200-1500, s. 47 (24,2); Sijmons - Wallis, Atlas de Santarem, s. 52-53 (plate 7, nr 5); Chekin, Northern Eurasia in Medieval Cartography, s. 106 (VII.3.2.). • Tekst legend mapy: Santarem, Essai sur l'histoire de la cosmographie, t. 2, s. 88-92. • Fragmenty tekstu legend mapy: Chekin, Northern Eurasia in Medieval Cartography, s. 106 
(VII.3.2.). • Źródło kopii: Chekin, Northern Eurasia in Medieval Cartography, s. 424 (VII.3.2.).

[24] „Watykańska” mapa Makrobiusza. • Źródło oryginału: Watykan, Biblioteca Apostolica Vaticana, Ms Pal. Lat. 1341, fol. 86 (średnica oryginału: $147 \mathrm{~mm}$; data powstania: XI w.). Por. Destombes, Mappemondes A.D. 12001500, s. 44 (20,15); Chekin, Northern Eurasia in Medieval Cartography, s. 99 (VII.2.12); Hiatt, The Map of Macrobius before 1100, s. 171 (4). • Tekst legend mapy: Hiatt, The Map of Macrobius before 1100, s. 173-175. • Źródło kopii: Chekin, Northern Eurasia in Medieval Cartography, s. 405 (VII.2.12.). Por. Englisch, Ordo orbis terrae, s. 57, rys. 11; Hiatt, The Map of Macrobius before 1100, s. 152 , rys. 3 .

[25] Wiktoryńska mapa ekumeny. • Źródło oryginału: Monachium, Bayerische Staatsbibliothek, CLM 10058, fol. 154v (średnica oryginału: $266 \mathrm{~mm}$; data powstania: XI/XII w.). Por. Destombes, Mappemondes A.D. 1200-1500, s. $32(4,6)$; Brincken, Fines Terrae, s. XVII (17); English, Ordo orbis terrae, s. 641; Chekin, Northern Eurasia in Medieval Cartography, s. 132-133 (X.4.). - Tekst legend mapy: Gautier Dalché, La „Descriptio mappe mundi” de Hugues de Saint-Victor, s. 193-195. • Fragmenty tekstu legend mapy: Chekin, Northern Eurasia in Medieval Cartography, s. 133-134 (X.4.). • Źródło kopii: Chekin, Northern Eurasia in Medieval Cartography, s. 450 (X.4.). Por. Gautier Dalché, La „Descriptio mappe mundi” de Hugues de Saint-Victor, tab. 1; M. Hoogvliet, Pictura et scriptura. Textes, images et herméneutique des mappae mundi (XIII ${ }^{e}-X V I^{e}$ siècle), Orbis Terrarum 7, Turnhout 2007, 358, rys. 5.

[26] „Paryska” mapa Makrobiusza II. • Źródło oryginału: Paryż, Bibliothèque Nationale, Ms Lat. 15170, fol. $125^{\mathrm{r}}$ (średnica oryginału: $66 \mathrm{~mm}$; data powstania: XI/XII w.). Por. Destombes, Mappemondes A.D. 1200-1500, s. 89-90 (36,9); Chekin, Northern Eurasia in Medieval Cartography, s. 112 (VIII.5.); Hiatt, The Map of Macrobius before 1100, s. 172 (50). • Tekst legend mapy: Gautier Dalché, Mappae mundi antérieures au XIII siècle, s. 146 (nr 72); Hiatt, The Map of Macrobius before 1100, s. 173-175; N. Bouloux, L'espace habité, w: La Terre. Connaissance, représentations, mesure au Moyen Âge, s. 359-361. • Fragmenty tekstu legend mapy: Destombes, Mappemondes A.D. 1200-1500, s. 89 (36,9); Chekin, Northern Eurasia in Medieval Cartography, s. 112-113 (VIII.5.). • Źródło kopii: Bouloux, L'espace habité, s. 360, rys. 4.

[27] „Florencka” mapa Makrobiusza I. • Źródło oryginału: Florencja, Biblioteca Medicea Laurenziana, Ms Plut. 76.33, fol. 47 (średnica oryginału: 106 mm; data powstania: XI/XII w.). Por. Destombes, Mappemondes A.D. 12001500, s. 44 (21,10); Chekin, Northern Eurasia in Medieval Cartography, s. 100 (VII.2.15.); Hiatt, The Map of Macrobius before 1100, s. 171 (20). • Tekst legend mapy: Hiatt, The Map of Macrobius before 1100, s. 173-175. • Źródło kopii: Chekin, Northern Eurasia in Medieval Cartography, s. 408 (VII.2.15.). 
[28] „Brukselska” mapa Makrobiusza. • Źródło oryginału: Bruksela, Bibliothèque Royale, Ms 10146, fol. 109 ${ }^{\mathrm{v}}$ (średnica oryginału: $83 \mathrm{~mm}$; data powstania: XI/XII w.). Por. Destombes, Mappemondes A.D. 1200-1500, s. 44 (21,5); Chekin, Northern Eurasia in Medieval Cartography, s. 100 (VII.2.16.); Hiatt, The Map of Macrobius before 1100, s. 171 (2). • Tekst legend mapy: Hiatt, The Map of Macrobius before 1100, s. 173-175. • Źródło kopii: Chekin, Northern Eurasia in Medieval Cartography, s. 409 (VII.2.16.).

[29] Mapa Beatusa z Silos. • Źródło oryginału: Londyn, British Library, Add. Ms 11695, fol. 39v-40r (wielkość oryginału: 430 x $320 \mathrm{~mm}$; data powstania: 1109). Por. Destombes, Mappemondes A.D. 1200-1500, s. 41 (17,9); Sijmons - Wallis, Atlas de Santarem, s. 57 (plate 13); Englisch, Ordo orbis terrae, s. 577; Chekin, Northern Eurasia in Medieval Cartography, s. 173 (XI.1.5.). - Tekst legend mapy: Santarem, Essai sur l'histoire de la cosmographie, t. 2, s. 107-126; Miller, Mappaemundi. Die ältesten Weltkarten, I. Heft, s. 37-38; Menéndez-Pidal, Mozárabes y Asturianos, s. 239 (legendy znajdują się na przerysie mapy); García-Aráez, Los mapamundis de los Beatos (2 $2^{\mathrm{a}}$ parte), s. 100123; English, Ordo orbis terrae, s. 576 (kopia przerysu G. Menéndez-Pidala). - Źródło kopii: Atlas. The Bulgarian Lands in the European Cartographic Tradition ( $3^{\text {rd }}-19^{\text {th }}$ Centuries), s. $42-43$ (I.1). Por. English, Ordo orbis terrae, s. 217, rys. 33; Baumgärtner, Graphische Gestalt und Signifikanz, s. 85, rys. 1 - niestety reprodukcja jest „odwrócona”; Scafi, Maps of Paradise, s. 37 i s. 50, rys. 27.

[30] Mapa Beatusa z Turynu. • Źródło oryginału: Turyn, Biblioteca Nazionale Universitaria, Ms I.II.1, fol. 45ㄴ $-46^{\mathrm{r}}$ (wielkość folium oryginału: 360 x $275 \mathrm{~mm}$; data powstania: pocz. XII w.). Por. Destombes, Mappemondes A.D. 1200-1500, s. 41 (17,10); Sijmons - Wallis, Atlas de Santarem, s. 54 (plate 8, nr 1); Englisch, Ordo orbis terrae, s. 613; Chekin, Northern Eurasia in Medieval Cartography, s. 174 (XI.2.2.). • Tekst legend mapy: Santarem, Essai sur l'histoire de la cosmographie, t. 2, s. 131-153; Cortambert, Quelques-uns des plus anciens monuments géographique du Moyen Âge, s. 339-345; Miller, Mappaemundi. Die ältesten Weltkarten, I. Heft, s. 38-41; Menéndez-Pidal, Mozárabes y Asturianos, s. 248 (legendy znajdują się na przerysie mapy); García-Aráez, Los mapamundis de los Beatos (2a parte), s. 100-123; English, Ordo orbis terrae, s. 612 (kopia przerysu G. Menéndez-Pidala). • Źródło kopii: English, Ordo orbis terrae, s. 318, rys. 55. Por. Baumgärtner, Graphische Gestalt und Signifikanz, s. 94, rys. 5; Scafi, Maps of Paradise, s. 49, rys. 26.

[31] Mapa Europy Lamberta z Saint-Omer. • Źródło oryginału: Gandawa, Bibliotheek der Rijksuniversiteit, Ms 92, fol. 241 ${ }^{\mathrm{r}}$ (wielkość oryginału: 207 x $175 \mathrm{~mm}$; data powstania: 1112/1115). Por. Destombes, Mappemondes A.D. 1200-1500, s. 115 (43,1); Brincken, Fines Terrae, s. XIX (33) i s. 73; Chekin, Northern Eurasia in Medieval Cartography, s. 191-192 (XIII.6.). • Tekst legend mapy: Miller, Mappaemundi. Die ältesten Weltkarten, III. Heft, s. 4751. • Fragmenty tekstu legend mapy: Chekin, Northern Eurasia in Medieval 
Cartography, s. 192 (XIII.6.). • Źródło kopii: Brincken, Studien zur Universalkartographie des Mittelalters, tablica 20. Por. Chekin, Northern Eurasia in Medieval Cartography, s. 490 (XIII.6.).

[32] Mapa z Sawley (dawniej: Mapa Henryka z Moguncji). • Źródło oryginału: Cambridge, Corpus Christi College, Ms 66, p. 2 (wielkość oryginału: 295 x 205 mm; data powstania: 1110/1180). Por. Destombes, Mappemondes A.D. 1200-1500, s. 48 (25,3); Sijmons - Wallis, Atlas de Santarem, s. 56 (plate 11); Brincken, Fines Terrae, s. XIX (31) i s. 68-71; English, Ordo orbis terrae, s. 637; Chekin, Northern Eurasia in Medieval Cartography, s. 137-139 (X.7.). - Tekst legend mapy: Miller, Mappaemundi. Die ältesten Weltkarten, III. Heft, s. 23-28; Lecoq, La mappemonde d'Henri de Mayence ou l'image du monde au $X I I^{e}$ siècle, s. 162-163. • Fragmenty tekstu legend mapy: Chekin, Northern Eurasia in Medieval Cartography, s. 139 (X.7.). • Źródło kopii: Reichert, Das Bild der Welt im Mittelalter, s. 32, rys. 2. Por. Scafi, Maps of Paradise, s. 54, rys. 28; J. Brotton, Stynne mapy, red. naukowa L. Szaniawska, Warszawa 2016, s. 51.

[33] Mapa hemisferyczna Lamberta z Saint-Omer (Wolfenbüttel): • Źródło oryginału: Wolfenbüttel, Herzog August Bibliothek, Ms Guelf. 1 Gudenus Lat., fol. $69^{\mathrm{v}}-70^{\mathrm{r}}$ (średnica oryginału: $392 \mathrm{~mm}$; data powstania: 1115/1180). Por. Destombes, Mappemondes A.D. 1200-1500, s. 115 (43,2); Brincken, Fines Terrae, s. XX (36) i s. 73-76; Chekin, Northern Eurasia in Medieval Cartography, s. 188 (XIII.2.2.). • Tekst legend mapy: Miller, Mappaemundi. Die ältesten Weltkarten, III. Heft, s. 47-51; R. Uhden, Die Weltkarte des Martianus Capella, „Mnemosyne” series III, 3 (1936) 122-124; D. Lecoq, La Mappemonde de „, Liber Floridus” ou la Vision du Monde de Lambert de Saint-Omer, „Imago Mundi” 39 (1987) 17. • Źródło kopii: Brincken, Studien zur Universalkartographie des Mittelalters, tab. 25. Por. Scafi, Maps of Paradise, s. 69, rys. 44; Edson - Savage-Smith - Brincken, Der mittelalterliche Kosmos, s. 63, rys. 45.

[34] Mapa hemisferyczna Lamberta z Saint-Omer (Leiden): • Źródło oryginału: Leiden, Bibliotheek der Rijksuniversiteit, Voss. Lat. F 31, fol. 175 ${ }^{\mathrm{v}}-176^{\mathrm{r}}$ (średnica oryginału: $290 \mathrm{~mm}$; data powstania: 1115/1300). Por. Destombes, Mappemondes A.D. 1200-1500, s. 115 (43,4); Chekin, Northern Eurasia in Medieval Cartography, s. 188 (XIII.2.4.). • Fragmenty tekstu legend mapy: Chekin, Northern Eurasia in Medieval Cartography, s. 189 (XIII.2.4.). • Źródło kopii: Brincken, Studien zur Universalkartographie des Mittelalters, tab. 26.

[35] Mapa Gwidona z Pizy. • Źródło oryginału: Bruksela, Bibliothèque Royale, Ms 3897-3919, fol. 53v (średnica oryginału: $130 \mathrm{~mm}$; data powstania: 1118). Por. Destombes, Mappemondes A.D. 1200-1500, s. 48 (25,2); Sijmons - Wallis, Atlas de Santarem, s. 51 (plate 6, nr 3); Brincken, Fines Terrae, s. XX (37) i s. 62-63; English, Ordo orbis terrae, s. 633; Chekin, Northern Eurasia in Medieval Cartography, s. 136-137 (X.6.). • Tekst legend mapy: Santarem, Essai sur l'histoire de la cosmographie, t. 2, s. 215-228; Miller, Mappaemundi. 
Die ältesten Weltkarten, III. Heft, s. 55-56; Chekin, Northern Eurasia in Medieval Cartography, s. 137 (X.6.). • Źródło kopii: Brincken, Studien zur Universalkartographie des Mittelalters, tab. 27. Por. English, Ordo orbis terrae, s. 632, rys. 2.17.1; Atlas. The Bulgarian Lands in the European Cartographic Tradition ( $3^{\text {rd }}-19^{\text {th }}$ Centuries), s. 47 (I.3).

[36] „Londyńska” mapa Makrobiusza. • Źródło oryginału: Londyn, British Library, Ms Harley 2652, fol. 48 (średnica oryginału: $87 \mathrm{~mm}$; data powstania: XII w.). Por. Destombes, Mappemondes A.D. 1200-1500, s. 45 (21,21); Chekin, Northern Eurasia in Medieval Cartography, s. 101 (VII.2.21.); Hiatt, The Map of Macrobius before 1100, s. 172 (42). • Tekst legend mapy: Hiatt, The Map of Macrobius before 1100, s. 173-175. • Źródło kopii: Chekin, Northern Eurasia in Medieval Cartography, s. 412 (VII.2.21.).

[37] „Oksfordzka” mapa Makrobiusza II. • Źródło oryginału: Oksford, Lincoln College, Ms Lat. 27, fol. 159v (średnica oryginału: $82 \mathrm{~mm}$; data powstania: XII w.). Por. Destombes, Mappemondes A.D. 1200-1500, s. 45 (21,30); Chekin, Northern Eurasia in Medieval Cartography, s. 102 (VII.2.25.). - Źródło kopii: Chekin, Northern Eurasia in Medieval Cartography, s. 416 (VII.2.25.).

[38] Mapa Makrobiusza z Baltimore. • Źródło oryginału: Baltimore, Walters Art. Museum, Ms W. 22 (De Ricci I, 477), fol. 64v (średnica oryginału: 103 mm; data powstania: XII w.). Por. Destombes, Mappemondes A.D. 1200-1500, s. 44 (21,2); Gautier Dalché, De la glose à la contemplation, s. 715; Chekin, Northern Eurasia in Medieval Cartography, s. 103 (VII.2.29.). • Źródło kopii: Chekin, Northern Eurasia in Medieval Cartography, s. 419 (VII.2.29.). Por. Destombes, Mappemondes A.D. 1200-1500, tablica XIIIc (O).

[39] Mapa O-T z Paryża. • Źródło oryginału: Paryż, Bibliothèque Nationale, Ms Lat. 11130, fol. $82^{\mathrm{r}}$ (średnica oryginału: $106 \mathrm{~mm}$; data powstania: XII w.). Por. Destombes, Mappemondes A.D. 1200-1500, s. 36 (9,3); Chekin, Northern Eurasia in Medieval Cartography, s. 68-69 (III.2.5.). • Tekst legend mapy: Gautier Dalché, Mappae mundi antérieures au XIII siècle, s. 144-145 (nr 67). • Źródło kopii: Chekin, Northern Eurasia in Medieval Cartography, s. 368 (III.2.5.).

[40] Mapa z „The Ryland Beatus”. • Źródło oryginału: Manchester, John Ryland University Library, Ms Lat. 8, fol. $43^{\mathrm{v}}-44^{\mathrm{r}}$ (wielkość oryginału: 455 x $650 \mathrm{~mm}$; data powstania: ok. 1175). Por. Destombes, Mappemondes A.D. 1200-1500, s.42 (13); English, Ordo orbis terrae, s. 605; Chekin, Northern Eurasia in Medieval Cartography, s. 174-175 (XI.2.3.). • Tekst legend mapy: Menéndez-Pidal, Mozárabes y Asturianos, s. 249 (legendy znajdują się na przerysie mapy); García-Aráez, Los mapamundis de los Beatos (2a parte), s. 100-123; English, Ordo orbis terrae, s. 604 (kopia przerysu G. MenéndezPidala). • Źródło kopii: English, Ordo orbis terrae, s. 304, rys. 50. 
[41] Mapa Beatusa z Lorvão. • Źródło oryginału: Lizbona, Arquivo Nacional da Torre do Tombo, Ms CXIII/247 (dawniej: Ms 160), fol. 34bis ${ }^{v}$ (wielkość otyginału: 350 x $230 \mathrm{~mm}$; data powstania: ok. 1189). Por. Destombes, Mappemondes A.D. 1200-1500, s. 42 (17,11); Brincken, Fines Terrae, s. XVIII (24) i s. 56-58; Chekin, Northern Eurasia in Medieval Cartography, s. 171 i przyp.1. • Tekst legend mapy: García-Aráez, Los mapamundis de los Beatos (2a parte), s. 100-123. • Źródło kopii: A. de Egry, Um estudo do Apocalipse de Lorvão e a sua relação com as ilustrações medievais do Apocalipse, Publicação Fundação Calouste Gulbenkian, Lisboa 1972, [130], tab. XVII.

[42] Mapa Beatusa z Nawarry. • Źródło oryginału: Paryż, Bibliothèque Nationale, Ms nouv. acq. lat. 1366, fol. $24^{\mathrm{v}}-25^{\mathrm{r}}$ (wielkość oryginału: 400 x 320 $\mathrm{mm}$; data powstania: koniec XII w.). Por. Destombes, Mappemondes A.D. 1200-1500, s. 42 (17,12); Brincken, Fines Terrae, s. XVIII (25) i s. 56-58; Chekin, Northern Eurasia in Medieval Cartography, s. 179 (XI.5.). • Tekst legend mapy: Miller, Mappaemundi. Die ältesten Weltkarten, I. Heft, s. 30-34; García-Aráez, Los mapamundis de los Beatos (2a parte), s. 100-123; Gautier Dalché, Mappae mundi antérieures au XIII siècle, s. 153-155 (nr 91). • Fragmenty tekstu legend mapy: Menéndez-Pidal, Mozárabes y Asturianos, s. 261 (legendy znajdują się na przerysie mapy); Chekin, Northern Eurasia in Medieval Cartography, s. 179 (XI.5.). • Zródło kopii: Baumgärtner, Graphische Gestalt und Signifikanz, s. 88, rys. 3.

[43] Beatus z Oña. • Źródło oryginału: Mediolan, Biblioteca Ambrosiana, Ms F 105 Sup., fol. $71^{\mathrm{v}}-72^{\mathrm{r}}$ (wielkość oryginału: brak danych; data powstania: koniec XII w.). Por. Brincken, Fines Terrae, s. XVIII (23) i s. 56-58; English, Ordo orbis terrae, s. 621; Chekin, Northern Eurasia in Medieval Cartography, s. 176 (XI.3.2.). • Tekst legend mapy: L. Vázquez de Parga, Un mapa desconocido de la serie de los «Beatos», w: Actas del Simposio para el estudio de los códices del «Comenatario al Apocalipsis» del Beato de Liébana, t. 1, Madrid, Joyas Bibliográficas, 1978, 277-278; García-Aráez, Los mapamundis de los Beatos (2a parte), s. 100-123. • Fragmenty tekstu legend mapy: Chekin, Northern Eurasia in Medieval Cartography, s. 176-177 (XI.3.2.). • Źródło kopii: www.atlantedellarteitaliana.com/artwork-4777.html [data dostępu: 17 VIII 2014]. Por. Vázquez de Parga, Un mapa desconocido de la serie de los «Beatos», między s. 276 a 277; J. Chocheyras, Fin des terres et fin des temps d'Hésychius (Viècle) à Béatus (VIII siècle), w: The Use and Abuse of Eschatology in the Middle Ages, ed. by W. Verbeke - D. Verhelst - A. Welkenhuysen, Mediaevalia Lovaniensia I/15, Leuven 1988, 80-81; English, Ordo orbis terrae, s. 336, rys. 59; s. 621, rys. 2.14 .1 ; s. 622 , rys. 2.14.3; I. Baumgärtner, Die Welt im kartographischen Blick. Zur Veränderbarkeit mittelalterlicher Weltkarten am Beispiel der Beatustradition vom 10. bis 13. Jahrhundert, w: Der weite Blick des Historikers. Einsichten in Kultur-, Landes- und Stadtgeschichte: Peter Johanek zum 65. Geburtstag, hrsg. von W. Ehbrecht, Köln 
2002, 544, rys. 8; taż, Visualisierte Weltenräume. Tradition und Innovation in den Weltkarten der Beatustradition des 10. bis 13. Jahrhunderts, w: Tradition, Innovation, Invention. Fortschrittsverweigerung und Fortschrittsbewusstsein im Mittelalter, hrsg. von H.-J. Schmidt, Scrinium Friburgense 18, Berlin - New York 2005, 272, rys. 13; Kochanek, „Rozestanie Apostołów” na mapie Beatusa z Burgo de Osma, s. 741, rys. 17; S. Sáenz-López Pérez, Peregrinatio in stabilitate: transformación de un mapa de los Beatos en herramienta de peregrinación espiritual, „Anales de Historia del Arte”, volumen extraordinario, 2011, 319, rys. 2.

[44] Tabula Peutingeriana. • Źródło oryginału: Wiedeń, Österreichische Nationalbibliothek, Codex Vindobonensis 324 (wielkość oryginału: 6750 x $340 \mathrm{~mm}$; data powstania: IV w. / kopia XII/XIII w.). • Tekst legend mapy: K. Miller, Die Peutingerische Tafel oder Weltkarte des Castorius, Stuttgart 1916; Tabula Peutingeriana: Codex Vindobonensis 324, [1:] Vollständige Faksimile-Ausgabe im Originalformat, hrsg. von E. Weber, Graz 1976; Tabula Peutingeriana. Die einzige Weltkarte aus der Antike, eingel. und kommentiert von M. Rathmann, 2. Aufl., Darmstadt 2017. • Źródło kopii: https:// en.wikipedia.org/wiki/History_of_Cagliari [data dostępu: 13 IX 2017].

[45] Mapa Europy Zachodniej Geralda z Walii. • Źródło oryginału: Mapa ta znajduje się między tekstem jego Topographia Hiberniae a Expugnatio Hibernica - Dublin, The National Library of Ireland, Cambrensis Codex, NLI Ms 700, fol. $48^{\mathrm{r}}$ (wielkość oryginału: 230 x $180 \mathrm{~mm}$; data powstania: ok. 1200). Por. Chekin, Northern Eurasia in Medieval Cartography, s. 139140 (X.8.). • Tekst legend mapy: A. Dürst, Manuskriptkarte von West-Europa, um 1200, „Cartographica Helvetica” 20 (1999) 36; Th. O’Loughlin, An Early Thirteenth-Century Map in Dublin: A Window into the World of Giraldus Cambrensis, „Imago Mundi” 51 (1999) 36-38. • Fragmenty tekstu legend mapy: Chekin, Northern Eurasia in Medieval Cartography, s. 140 (X.8.). - Zródło kopii: Dürst, Manuskriptkarte von West-Europa, um 1200, s. 37. Por. O'Loughlin, An Early Thirteenth-Century Map in Dublin, s. 27, rys. 1 oraz plate 2; W. Nöth, Medieval Maps: Hybrid Ideographic and Geographic Sign Systems, w: Herrschaft verorten. Politische Kartographie im Mittelalter und in der frühen Neuzeit, hrsg. von I. Baumgärtner und M. Stercken, Medienwandel - Medienwechsel - Medienwissen 19, Zürich 2012, 341, rys. 2; D. Birkholz, Hereford Maps, Hereford lives. Biography and cartography in an English cathedral city, w: Mapping Medieval Geographies, s. 232, rys. 10.1.

[46] Mapa Beatusa z Las Huelgas. • Źródło oryginału: Nowy Jork, Pierpont Morgan Library, Ms 429, fol. $31^{\mathrm{v}}-32^{\mathrm{r}}$ (wielkość oryginału: 560 x 380 mm; data powstania:1220). Por. Destombes, Mappemondes A.D. 1200-1500, s. 83 (35,1); English, Ordo orbis terrae, s. 609; Chekin, Northern Eurasia in Medieval Cartography, s. 175 (XI.2.4.). • Tekst legend mapy: Menéndez-Pidal, Mozárabes y Asturianos, s. 250 (legendy znajdują się na przerysie mapy); 
García-Aráez, Los mapamundis de los Beatos (2a parte), s. 100-123; English, Ordo orbis terrae, s. 612 (kopia przerysu G. Menéndez-Pidala). • Źródło kopii: English, Ordo orbis terrae, s. 312, rys. 53. Por. Baumgärtner, Graphische Gestalt und Signifikanz, s. 95, rys. 6.

[47] „Florencka” mapa Makrobiusza II. • Źródło oryginału: Florencja, Biblioteca Medicea Laurenziana, Ms Plut. 22 sin. 11, fol. 87 $7^{\mathrm{r}}$ (średnica oryginału: $78 \mathrm{~mm}$; data powstania: XIII w.). Por. Destombes, Mappemondes A.D. 1200-1500, s. 88 (36,3); Chekin, Northern Eurasia in Medieval Cartography, s. 103-104 (VII.2.33.). • Fragmenty tekstu legend mapy: Destombes, Mappemondes A.D. 1200-1500, s. 88-89 (36,3). • Źródło kopii: Chekin, Northern Eurasia in Medieval Cartography, s. 422 (VII.2.33.).

[48] Mapa Beatusa z Arroyo. • Źródło oryginału: Paryż, Bibliothèque Nationale, Ms nouv. acq. lat. 2290, fol. $13^{\mathrm{v}}-14^{\mathrm{r}}$ (średnica oryginału: $400 \mathrm{~mm}$; data powstania: poł. XIII w.). Por. Destombes, Mappemondes A.D. 1200-1500, s. 83-84 (35,2); English, Ordo orbis terrae, s. 617; Chekin, Northern Eurasia in Medieval Cartography, s. 175 (XI.2.5.). • Tekst legend mapy: Miller, Mappaemundi. Die ältesten Weltkarten, I. Heft, s. 38-41; García-Aráez, Los mapamundis de los Beatos (2 ${ }^{\text {a }}$ parte), s. 100-123; Gautier Dalché, Mappae mundi antérieures au XIII ${ }^{e}$ siècle, s. 158-159 (nr 101). • Fragmenty tekstu legend mapy: Menéndez-Pidal, Mozárabes y Asturianos, s. 251 (legendy znajduja się na przerysie mapy); English, Ordo orbis terrae, s. 616 (kopia przerysu G. Menéndez-Pidala); Chekin, Northern Eurasia in Medieval Cartography, s. 179 (XI.5.). • Źródło kopii: English, Ordo orbis terrae, s. 326, rys. 57. Por. Baumgärtner, Graphische Gestalt und Signifikanz, s. 96, rys. 7.

[49] Mapa świata (I) Mateusza Paris. • Źródło oryginału: Cambridge, Corpus Christi College, Ms 26, p. 284 (wielkość oryginału: 354 x 232 mm; data powstania: ok. 1250). Por. Destombes, Mappemondes A.D. 1200-1500, s. 246 (54,1); Brincken, Fines Terrae, s. XXI (45); Chekin, Northern Eurasia in Medieval Cartography, s. 196 (XIV.1.1.). • Tekst legend mapy: Miller, Mappaemundi. Die ältesten Weltkarten, III. Heft, s. 71-73. • Źródło kopii: Chekin, Northern Eurasia in Medieval Cartography, s. 491 (XIV.1.1.).

[50] Mapa świata (II) Mateusza Paris. • Źródło oryginału: Londyn, British Library, Ms Cotton Nero D. V., fol. 1 ${ }^{v}$ (wielkość oryginału: 348 x $236 \mathrm{~mm}$; data powstania: ok. 1250). Por. Destombes, Mappemondes A.D. 1200-1500, s. 246 (54,2); Sijmons - Wallis, Atlas de Santarem, s. 61 (plate 18); Brincken, Fines Terrae, s. XXI (46); Chekin, Northern Eurasia in Medieval Cartography, s. 196 (XIV.1.2.). • Tekst legend mapy: Santarem, Essai sur l'histoire de la cosmographie, t. 2, s. 257-272; Miller, Mappaemundi. Die ältesten Weltkarten, III. Heft, s. 71-73. • Fragmenty tekstu legend mapy: Chekin, Northern Eurasia in Medieval Cartography, s. 196-197 (XIV.1.2.). • Źródło kopii: Atlas. The Bulgarian Lands in the European Cartographic Tradition $\left(3^{r d}-19^{\text {th }}\right.$ 
WPEYW STAROŻYTNEJ SCHEMATYZACJI MNEMOTECHNICZNEJ NA KARTOGRAFIĘ 357

Centuries), s. 58 (I.7). Por. Chekin, Northern Eurasia in Medieval Cartography, s. 492 (XIV.1.2.).

[51] Mapa Brytanii Mateusza Paris. • Źródło oryginału: Londyn, British Library, Ms Royal 14 C VII, fol. 5v (wielkość folium oryginału: 360 x 245 mm; data powstania: 1250-1259). • Tekst legend mapy: Miller, Mappaemundi. Die ältesten Weltkarten, III. Heft, s. 75-82. • Źródło kopii: Foxell, Mapping England, s. 32.

[52] Mapa z Psałterza Londyńskiego. • Źródło oryginału: Londyn, British Library, Ms Add. 28681, fol. $9^{\mathrm{r}}$ (średnica oryginału: $90 \mathrm{~mm}$; data powstania: ok. 1260). Por. Destombes, Mappemondes A.D. 1200-1500, s. 168-170 (49,8); Brincken, Fines Terrae, s. XXII (51) i s. 85-89; English, Ordo orbis terrae, s. 645; Chekin, Northern Eurasia in Medieval Cartography, s. 140-141 (X.9.1.). • Tekst legend mapy: Miller, Mappaemundi. Die ältesten Weltkarten, III. Heft, s. 38-42. • Fragmenty tekstu legend mapy: Chekin, Northern Eurasia in Medieval Cartography, s. 141-142 (X.9.1.). • Źródło kopii: Chekin, Northern Eurasia in Medieval Cartography, s. 455 (X.9.1.). Por. J. Goss, KartenKunst. Die Geschichte der Kartographie, übers. aus dem Engl. von E. Heinemann und R. Tiffert, Braunschweig 1994, 35, rys. 2.4; English, Ordo orbis terrae, s. 440, rys. 76; Atlas. The Bulgarian Lands in the European Cartographic Tradition (3 $3^{r d}-19^{\text {th }}$ Centuries), s. 51 (I.5); Edson - Savage-Smith - Brincken, Der mittelalterliche Kosmos, s. 66, rys. 48; U. Schneider, Die Macht der Karten. Eine Geschichte der Kartographie vom Mittelalter bis heute, 3. Aufl., Darmstadt 2012, 29, rys. 15; Reichert, Das Bild der Welt im Mittelalter, s. 34, rys. 4; Scafi, Maps of Paradise, s. 70, rys. 45; K. Whittington, Body-Worlds. Opicinus de Canistris and the Medieval Cartographic Imagination, Studies and Texts 186, Toronto 2014, 55, rys. 11.

[53] Rotulus z Vercelli. • Źródło oryginału: Vercelli, Archivio Capitolare (wielkość oryginału: 840 x 700/720 mm; data powstania: ok. 1270). Por. Destombes, Mappemondes A.D. 1200-1500, s. 193-194 (52,1); A.-D. von den Brincken, Monumental Legends on Medieval Manuscript Maps. Notes on designed capital letters on maps of large size (demonstrated from the Problem of dating the Vercelli Map, thirteenth century), „Imago Mundi” 42 (1990) 9-25 (= taż, Studien zur Universalkartographie des Mittelalters, s. 375-399); taż, Fines Terrae, s. XXII (55) i s. 90-91; Chekin, Northern Eurasia in Medieval Cartography, s. 142-143 (X.10.). • Fragmenty tekstu legend mapy: Chekin, Northern Eurasia in Medieval Cartography, s. 144-146 (X.10.). • Zródło kopii: Chekin, Northern Eurasia in Medieval Cartography, s. 457 (X.10.). Por. Destombes, Mappemondes A.D. 1200-1500, tablica XXIII (Planche AA); L. Bagrow - R.A. Skelton, Meister der Kartographie, 5. Aufl., Frankfurt am Main - Berlin 1985, 318, rys. XXXII; Wilke, Die Ebstorfer Weltkarte, II: Tafelband, s. 47, rys. 10; Brinkken, Studien zur Universalkartographie des Mittelalters, tab. 49. 
[54] Mapa z Ebstorf, por. przyp. 33 oraz rys. 10. • Duże, kolorowe reprodukcje mapy: Miller, Mappaemundi. Die ältesten Weltkarten, V. Heft - facsimile mapy w formie wkładki za tylną okładką; G. Grosjean, R. Kinauer, Kartenkunst und Kartentechnik vom Altertum bis zum Barock, Bern und Stuttgart 1970, 26-27; Bagrow - Skelton, Meister der Kartographie, s. 98; Wilke, Die Ebstorfer Weltkarte, II: Tafelband - mapa została dodana w formie wkładki; Atlas. The Bulgarian Lands in the European Cartographic Tradition $\left(3^{r d}-19^{\text {th }}\right.$ Centuries), s. 53-54 (I.6); C.J. Schüler, Die Geschichte der Kartographie, Paris 2010, 17; Schneider, Die Macht der Karten, s. 24-25, rys. 11; Scafi, Maps of Paradise, s. 73, rys. 47 i s. 74-75; Wendt, Skarby kartografii, s. 56-57. Jednak najlepsza kopia mapy znajduje się w internecie: www.uni-lueneburg.de/ hyperimage/EbsKart/start.html [data dostępu: 13 IX 2017].

[55] Mapa z Hereford. • Źródło oryginału: Hereford, The New Library at Hereford Cathedral (wielkość oryginału: 1626 x $1346 \mathrm{~mm}$; data powstania: 1276/1305). Por. Destombes, Mappemondes A.D. 1200-1500, s. 197-202 (52,3); Brincken, Fines Terrae, s. XXII-XXIII (58) i s. 93-95; English, Ordo orbis terrae, s. 649; Chekin, Northern Eurasia in Medieval Cartography, s. 161163 (X.12.). • Tekst legend mapy: Bevan - Phillott, Mediaeval Geography, passim; Miller, Mappaemundi. Die ältesten Weltkarten, IV. Heft, passim; Westrem, The Hereford Map, passim. • Fragmenty tekstu legend mapy: J. Lelewel, Géographie du Moyen Age, t. 2, Bruxelles 1852 [reprint: Amsterdam 1966], 6-7; Hallberg, L'Extrème Orient dans la littérature et la cartographie (nazwy geograficzne w porządku alfabetycznym); Chekin, Northern Eurasia in Medieval Cartography, s. 163-168 (X.12.). • Zródło kopii: Schüler, Die Geschichte der Kartographie, s. 18. Por. Miller, Mappaemundi. Die ältesten Weltkarten, IV. Heft - facsimile mapy w formie wkładki; Westrem, The Hereford Map, s. LX-LXXXIV (mapa została tu podzielona na 12 sekcji); Chekin, Northern Eurasia in Medieval Cartography, s. 467 (X.12.); Scafi, Maps of Paradise, s. 61, rys. 31 i s. 62-63; Wendt, Skarby kartografii, s. 55; Brotton, Stynne mapy, s. 56.

[56] Mapa z Lambeth Palace Library (ok. 1300), por. przyp. 34 i 39 oraz rys. 11.

[57] Mapa Pietro Vesconte. • Źródło oryginału: Londyn, British Library, Add. Ms 27376, fol. $8^{\mathrm{v}}{ }^{-9}$ (średnica oryginału: $350 \mathrm{~mm}$; data powstania: ok. 1321). Por. Destombes, Mappemondes A.D. 1200-1500, s. $246(54,8)$. $\bullet$ Tekst legend mapy: Miller, Mappaemundi, III. Heft, s. 132-136. • Fragmenty tekstu legend mapy: Hallberg, L'Extrême Orient dans la littérature et la cartographie (nazwy geograficzne w porządku alfabetycznym). • Źródło kopii: Scafi, Maps of Paradise, s. 88-89, rys. 54. Por. Whittington, Body-Worlds, s. 56, rys. 12. - Por. też inną dobrą kolorową reprodukcję mapy z tej serii: N. Bouloux, Culture et savoirs géographiques en Italie au XIV siècle, Terrarum Orbis 2, Turnhout 2002, tab. 1 = Watykan, Biblioteca Apostolica Vaticana, Ms Vat. Lat. 
2972, fol. $112^{\mathrm{v}}-113^{\mathrm{r}}$ (średnica oryginału: $270 \mathrm{~mm}$; data powstania: ok. 1321). Por. Destombes, Mappemondes A.D. 1200-1500, s. 246 (54,13).

[58] Paulinus Minorita (= Paulinus Venetus): Mapa (I) Italii. • Źródło oryginału: Watykan, Biblioteca Apostolica Vaticana, Ms Vat. Lat. 1960, fol. $266^{\mathrm{v}}$ (wielkość folium oryginału: $442 \times 285 \mathrm{~mm}$; data powstania: ok. 1320). - Źródło kopii: Bouloux, Culture et savoirs géographiques en Italie au XIVe siècle, tab. 4.

[59] Paulinus Minorita (= Paulinus Venetus): Mapa (II) Italii. • Źródło oryginału: Watykan, Biblioteca Apostolica Vaticana, Ms Vat. Lat. 1960, fol. $268^{\mathrm{r}}$ (wielkość folium oryginału: 442 x $285 \mathrm{~mm}$; data powstania: ok. 1320). - Źródło kopii: Bouloux, Culture et savoirs géographiques, tab. 5. Por. P.D.A. Harvey, Medieval Maps of the Holy Land, London 2012, 16, rys. 6: tutaj mapa ta jest datowana w przedziale lat 1334-1339.

[60] Paulinus Minorita (= Paulinus Venetus): Mapa świata. • Źródło oryginału: Paryż, Bibliothèque Nationale, Ms Lat. 4939, fol. $9^{\text {r }}$ (średnica oryginału: $320 \mathrm{~mm}$; data powstania: ok. 1320). Por. Destombes, Mappemondes A.D. 1200-1500, s. 246 (54,10); Sijmons - Wallis, Atlas de Santarem, s. 61 (plate 19 = Marino Sanudo); Brincken, Fines Terrae, s. XXIII-XXIV (66) i s. 115-116. • Tekst legend mapy: Santarem, Essai sur l'histoire de la cosmographie, t. 3, s. 141-173; Miller, Mappaemundi. Die ältesten Weltkarten, III. Heft, s. 132-136. • Źródło kopii: http://gallica.bnf.fr/ark:/12148/ btv1b55002483j/f25.item [data dostępu: 13 IX 2017].

[61] Paulinus Minorita (= Paulinus Venetus): Mapa Bliskiego Wschody. - Źródło oryginału: Paryż, Bibliothèque Nationale, Ms Lat. 4939, fol. $10^{\mathrm{r}}$ (wielkość mapy: ok. 260 x 350 mm; data powstania: ok. 1320). • Źródło kopii: E. Vagnon, Cartographie et Représentations de l'Orient méditerranéen en Occident (du milieu du XIII è la fin du XV siècle), Orbis Terrarum 11, Turnhout 2013, planche 5. • Tekst pod mapa (pomocny w analizie samej mapy): M. Di Cesare, Studien zu Paulinus Venetus „,De mapa mundi”, MGH. Studien und Texte 58, Wiesbaden 2015, 101-118 (Anhang 1: szczeg. s. 109-112).

[62] Opicinus de Canistris: „Europa - Nierządnica”. • Źródło oryginału: Watykan, Biblioteca Apostolica Vaticana, Ms Vat. Lat. 6435, fol. 77 (wielkość folium oryginału: 215 x $315 \mathrm{~mm}$; data powstania: 1337-1341). $\bullet$ Tekst legend mapy: por. przyp. 122. • Źródło kopii: Whittington, Body-Worlds, s. 152, rys. 36. Por. M. de La Roncière, M. Mollat du Jourdin, Portulane. Seekarten vom 13. bis zum 17. Jahrhundert, übers. von R. Beyer, München 1984, 19; M. Laharie, Une cartographie «à la folie»: Le journal d'Opicinus de Canistris (Bibliothèque Apostolique Vaticane, Cod. Vat. Lat. 6435), „Mélanges de l'École Française de Rome. Moyen Âge" 119 (2007) nr 2, 390, rys. 8. 
[63] Mapa Ranulfa Higdena z „Polychronicon”. • Źródło oryginału: Londyn, British Library, Royal Ms 14 C. IX, fol. $1^{\mathrm{v}}-2^{\mathrm{r}}$ (wielkość oryginału: 465 x 342 mm; ok. 1342). Por. Destombes, Mappemondes A.D. 1200-1500, s. 153-154 (47,1); Sijmons - Wallis, Atlas de Santarem, s. 61 (plate 16); Brincken, Fines Terrae, s. XXIII (61) i s. 112-113; Baumgärtner, Graphische Gestalt und Signifikanz, s. 107, przyp. 68. • Tekst legend mapy: Santarem, Essai sur l'histoire de la cosmographie, t. 3, s. 4-60; J. Lelewel, Epilog de la géographie du Moyen Âge, Bruxelles 1857 [reprint: Amsterdam 1966], 145-167 (szczeg. s. 146-161); Miller, Mappaemundi. Die ältesten Weltkarten, III. Heft, s. 99-108. • Fragmenty tekstu legend mapy: Lelewel, Géographie du Moyen Age, t. 2, s. 14-15; Hallberg, L'Extrème Orient dans la littérature et la cartographie (nazwy geograficzne w porządku alfabetycznym). • Źródło kopii: Scafi, Maps of Paradise, s. 171, rys. 104. Por. Baumgärtner, Graphische Gestalt und Signifikanz, s. 108, rys. 9.

[64] Atlas Kataloński. • Źródło oryginału: Paryż, Bibliothèque Nationale, Ms Esp. 30 (wielkość oryginału: 500 x 2600 mm; data powstania: 1375-1380). Por. Sijmons - Wallis, Atlas de Santarem, s. 66 (plate 35 i 36); Brincken, Fines Terrae, s. XXIV (71) i s. 117-118. • Tekst legend mapy: Mapamundi. Der katalanische Weltatlas vom Jahre 1375, hrsg. und kommentiert von G. Grosjean, Dietikon-Zürich 1977. • Fragmenty tekstu legend mapy: Hallberg, L'Extrème Orient dans la littérature et la cartographie (nazwy geograficzne w porządku alfabetycznym). • Przekład francuski tekstu legend mapy: Lelewel, Géographie du Moyen Age, t. 2, 48-67. • Źródło kopii: Der Katalanische Weltaltlas vom Jahre 1375 nach dem in der Bibliothèque Nationale, Paris, verwahrten Original farbig wieder gegeben, mit einer Einführung und Übersetzungen von H.-Ch. Freiesleben, Quellen und Forschungen zur Geschichte der Geographie und der Reisen 11, Stuttgart 1977. Por. Goss, KartenKunst. Die Geschichte der Kartographie, s. 46-47, tab. 2.16 (kolorowa reprodukcja czterech sekcji atlasu); Hoogvliet, Pictura et scriptura, s. 370-371, rys. 15 (kolorowa reprodukcja czterech sekcji atlasu); Brotton, Stynne mapy, 62-63 (cały atlas w kolorze) i s. 64-65 (wybrane detale).

[65] Mapa z Kompendium Wiedeńskiego (XIV w.), por. przyp. 32 i 40 oraz rys. 12 .

[66] Wczesnoptolemejska mapa Europy. • Źródło oryginału: Paryż, Bibliothèque Nationale, Ms Lat. 3123, fol. 169 $-170^{\mathrm{r}}$ (wielkość oryginału: brak danych; data powstania: 1427). • Źródło kopii: Gautier Dalché, La Géographie de Ptolémée en Occident (IVe-XVIe siècle), s. 413, rys. VII.

[67] Mapa Italii z Aix-en-Provence. • Źródło oryginału: Aix-en-Provence, Bibliothèque municipale, Ms 1452, fol. $008^{v}$ (wielkość oryginału: brak danych; data powstania: 1 poł. XV w.). • Źródło kopii: http://bvmm.irht.cnrs.fr/ consult/consult.php?reproductionId=7143 (Bibliothèque Virtuelle des Manuscrits Médiévaux) [data dostępu: 18 IX 2017]. 
[68] Mapa Giovanniego Leardo: • Źródło oryginału: Werona, Biblioteca Comunale, Ms 3119 (średnica mapy: 215 mm; data powstania: 1442). Por. Destombes, Mappemondes A.D. 1200-1500, s. 208-209 (52,7). • Fragmenty tekstu legend mapy: Hallberg, L'Extrème Orient dans la littérature et la cartographie (nazwy geograficzne w porządku alfabetycznym). • Źródło kopii: Scafi, Maps of Paradise, s. 25 i s. 33, rys. 15.

[69] Andreas Walsperger. • Źródło oryginału: Rzym, Biblioteca Apostolica Vaticana, Ms. Pal. Lat. 1362b (średnica oryginału: $425 \mathrm{~mm}$; data powstania: 1448). Por. Destombes, Mappemondes A.D. 1200-1500, s. 212 (52,10); Brincken, Fines Terrae, s. XXV (80) i s. 145-147. - Tekst legend mapy: K. Kretschmer, Eine neue mittelalterliche Weltkarte der vatikanischen Bibliothek, ,Zeitschrift der Gesellschaft für Erdkunde zu Berlin” 26 (1891) 371-406; Miller, Mappaemundi. Die ältesten Weltkarten, III. Heft, s. 147-148. • Fragmenty tekstu legend mapy: Hallberg, L'Extrême Orient dans la littérature et la cartographie (nazwy geograficzne w porządku alfabetycznym); Destombes, Mappemondes A.D. 1200-1500, s. 212-214 (52,10). • Źródło kopii: Atlas. The Bulgarian Lands in the European Cartographic Tradition ( $3^{r d}-19^{\text {th }}$ Centuries), s. 67-68 (I.11). Por. Brincken, Studien zur Universalkartographie des Mittelalters, tab. 65; Scafi, Maps of Paradise, s. 90, rys. 55.

[70] Mapa z Modeny. • Źródło oryginału: Modena, Biblioteca Estense, C.G.A. 1 (średnica oryginału: $1130 \mathrm{~mm}$; data powstania: 1450-1460). Por. Destombes, Mappemondes A.D. 1200-1500, s. 217-221 (52,12); Brincken, Fines Terrae, s. XXV (79) i s. 119. • Tekst legend mapy: K. Kretschmer, Die Katalanische Weltkarte der Biblioteca Estense zu Modena, ,Zeitschrift der Gesellschaft für Erdkunde zu Berlin" 32 (1897) 65-111 i 191-218. • Fragmenty tekstu legend mapy: Destombes, Mappemondes A.D. 1200-1500, s. 217-219 (52,12). - Źródło kopii: Scafi, Maps of Paradise, s. 91, rys. 56. Por. Goss, KartenKunst. Die Geschichte der Kartographie, s. 45, rys. 2.15; Hoogvliet, Pictura et scriptura, s. 372, rys. 16; Reichert, Das Bild der Welt im Mittelalter, s. 74, rys. 10.

[71] Mapa Genueńska. • Źródło oryginału: Florencja, Biblioteca Nazionale Centrale, Portolano nr 1 (wielkość oryginału: 750 × $370 \mathrm{~mm}$; data powstania: 1457). Por. Destombes, Mappemondes A.D. 1200-1500, s. 222-223 (52,13). - Tekst legend mapy: Lelewel, Épilog de la géographie du Moyen Âge, s. 167184 (szczeg. s. 167-175); T. Fischer, Sammlung mittelalterlicher Welt- und Seekarten italienischen Ursprungs und aus italienischen Bibliotheken und Archiven, Venedig 1886 [reprint: Amsterdam 1961], 155-206. • Fragmenty tekstu legend mapy: H. Wuttke, Die Karten der seefahrenden Völker Südeuropas bis zum ersten Druck der Erdbeschreibung des Ptolemäus. Zur Geschichte der Erdkunde im letzten Drittel des Mittelalters, Dresden 1871 [reprint: Amsterdam 1961], $42-47$ (szczeg. s. 45-47); G. Marinelli, Gog e Magog. Leggenda geografica, „Cosmos” 7 (1882-1883) 203; Hallberg, L'Extrême Orient dans la littérature et la cartographie (nazwy geograficzne w porządku alfabetycznym). 
- Źródło kopii: A. Cattaneo, Fra Mauro's Mappa Mundi and Fifteenth-Century Venice, Orbis Terrarum 8, Turnhout 2011, tab. V. Por. Bagrow - Skelton, Meister der Kartographie, s. 74; Wendt, Skarby kartografii, s. 70-71.

[72] Mapa Fra Mauro. • Źródło oryginału: Wenecja, Biblioteca Nazionale Marciana (średnica oryginału: $1960 \mathrm{~mm}$; data powstania: 1459). Por. Destombes, Mappemondes A.D. 1200-1500, s. 223-226 (52,14); Sijmons - Wallis, Atlas de Santarem, s. 69 (plate 45-50). • Tekst legend mapy: P. Falchetta, Frau Mauro 's World Map, Terrarum Orbis 5, Turnhout 2006. • Fragmenty tekstu legend mapy: P. Zurla, Il mappamondo di Fra Mauro Camaldolese, Venezia 1806, s. 17-78; Lelewel, Géographie du Moyen Age, t. 2, s. 92-95; Hallberg, L'Extrème Orient dans la littérature et la cartographie (nazwy geograficzne w porządku alfabetycznym). • Źródło kopii: Schneider, Die Macht der Karten, s. 14-15, rys. 4. Por. Falchetta, Frau Mauro's World Map - CD-ROM w kieszeni przyklejone do tylnej okładki: „Fra Mauro’s World Map”. To dziś najlepsza reprodukcja tej mapy; Cattaneo, Fra Mauro 's Mappa Mundi and Fifteenth-Century Venice, duża reprodukcja mapy w formie wkładki; Brotton, Stynne mapy, s. 72-73.

[73] Mapa Borgia. • Źródło oryginału: Rzym, Biblioteca Apostolica Vaticana, Fondo Borgiano XVI (średnica oryginału: $630 \mathrm{~mm}$; data powstania: ok. 1460). Por. Destombes, Mappemondes A.D. 1200-1500, s. 239-241 (53,1); Sijmons - Wallis, Atlas de Santarem, s. 64 (plate 27); Brincken, Fines Terrae, s. XXV (78). • Tekst legend mapy: A.H.L. Heeren, Explicatio planiglobii, orbis terrarvm faciem exhibentis, ante medivm saecvlvm XV. svmma arte confecti; Mvsei Borgiani Velitris; agitantvr simvl de historia mapparvm geographicarvm recte institvenda consilia, „Commentationes Societatis Regiae Scientiarum Gottingensis Classis Historicae et Philologicae" 16 (1808) 250284 (szczeg. s. 260-284); Santarem, Essai sur l'histoire de la cosmographie, t. 3, s. 251-300; Lelewel, Géographie du Moyen Age, t. 2, s. 97-103; Miller, Mappaemundi. Die ältesten Weltkarten, III. Heft, s. 149-150. • Źródło kopii: Atlas. The Bulgarian Lands in the European Cartographic Tradition $\left(3^{r d}-19^{\text {th }}\right.$ Centuries), s. 65-66 (I.10). Por. Destombes, Mappemondes A.D. 1200-1500, s. XXIX (Planche V).

[74] Mapa z Zeitz. • Źródło oryginału: Zeitz, Stiftbibliothek, Ms Hist. Fol. 497, fol. $48^{\mathrm{r}}\left(2^{\circ}\right.$ Ms. chart. 105an) (średnica oryginału: $225 \mathrm{~mm}$; data powstania: 1470). Por. Destombes, Mappemondes A.D. 1200-1500, s. 247 (54,17); Brincken, Fines Terrae, s. XXVI (82). • Źródło kopii: Brincken, Studien zur Universalkartographie des Mittelalters, tablica 69. Por. Bagrow - Skelton, Meister der Kartographie, s. 343, rys. LVIII.

[75] Mapa Salustiusza z Genewy: • Źródło oryginału: Genewa, Bibliothèque de Genève, Ms Lat. 54 (Inv. 133), fol. 34v (średnica oryginału: $125 \mathrm{~mm}$; data powstania: XV w.). Por. Destombes, Mappemondes A.D. 1200-1500, s. 71 (31,11); Brincken, Fines Terrae, s. XXV (76) i s. 138-139. • Tekst legend mapy: 
Miller, Mappaemundi. Die ältesten Weltkarten, III. Heft, s. 141-143. • Źródło kopii: Brincken, Studien zur Universalkartographie des Mittelalters, tab. 66.

Aneks II

Najpopularniejsze schematy antyczne stosowane w geografii ${ }^{211}$

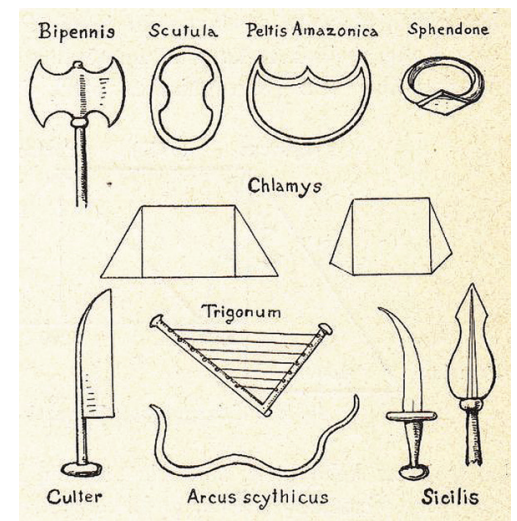

\section{THE INFLUENCE OF THE ANCIENT MNEMONIC SCHEMATISATION FOR MEDIEVAL AND EARLY-MODERN CARTOGRAPHY}

(Summary)

The article analyzes the ancient geographical schemes seen on the 75 medieval and early modern maps. Here distinguishes three types of schemes: 1. geographical and geometric, 2. chorographic, 3. topographic. The first type is based on the Globe of Crates of Malos and the acrostic of the name Adam. The second type includes Sicily, having a triangle scheme; Sardinia, having the shape of a human foot; Cyclades and Orkney, taking the form of a circle; Italia, having the shape of a triangle, a quadrangle, bull horns or the famous „Stivale”; Spain also schematized in the form of a triangle; Alps presented as ramparts of Italy and the mouth of the Nile, Rhine, Danube, Ganges and Indus in the form of the Greek letter delta. An example of the third type is the Caspian and Nubian Gates. The conclusion of the article is that, among the great number of ancient geographical schemes, medieval cartography preserved only those that survived in the encyclopedic works of such authors as Pliny, Solinus, Orosius, Macrobius, Martianus Capella, Isidore of Seville and Rabanus Maurus.

${ }^{211}$ Zamieszczona wyżej tabela pochodzi z: Miller, Mappaemundi. Die ältesten Weltkarten, VI. Heft, s. 119, rys. 44. Por. Kochanek, Iluzja schematów choro- i topograficznych, s. 125. 
Key words: medieval cartography, early-modern cartography, mnemonics, schematisation.

Słowa kluczowe: kartografia średniowieczna, kartografia wczesnonowożytna, mnemotechnika, schematyzacja

\section{BIBLIOGRAFIA}

\section{Źródła}

Absalon Sprinckirsbacensis, Sermones, PL 211, 13A-294D.

Aelredus Rievallensis, Sermo in adventu Domini, PL 184, 817B-828B.

Alanus de Insulis, Elucidatio in Cantica canticorum, PL 210, 51A-110B.

Alanus de Insulis, Dictiones dictionum theologicalium, PL 210, 685A-1012D.

Alcuinus, Commentaria in Apocalypsin, PL 100, 1087A-1156C.

Alcuinus, Enchiridion, PL 100, 570D-638C.

Ambrosius, De virginitate, ed. E. Cazzaniga, Corpus Scriptorum Latinorum Paravianum, Torino 1954 (= PL 16, 279A-316B).

Ammianus Marcellinus, Res gestae, rec. V. Gardthausen, vol. 1, Lipsiae 1874.

Anselmus Laudunensis, Enarrationes in Cantica canticorum, PL 162, 1187A-1228B.

Arrianus, Alexandri anabasis, w: tenże, Quae exstant omnia, vol. 1: Alexandri anabasis, ed. A.G. Roos, Lipsiae 1907.

Augustinus, De civitate Dei, ed. E. Hoffmann, CSEL 40/1-2, Wien 1899-1900 (= CCL 47-48 = PL 41, 13-804).

Augustinus, Enarrationes in Psalmos 101-150, pars I: Enarrationes in Psalmos 119-133, ed. F. Gori, CSEL 95/3, Wien 2001 (= PL 36, 1596-1738).

Aulus Gellius, Noctes Atticae, ed. C. Hosius, vol. 1-2, Lipsiae 1903.

Avienus, Descriptio orbis terrae, w: Geographi Graeci Minores, vol. 2, s. 177-189.

Beda Venerabilis, In Cantica canticorum libri III, w: tenże, Opera, pars II: Opera exegetica, 2B: In Tobiam, In Proverbia, In Cantica canticorum, ed. D. Hurst, In Habacuc, ed. J.E. Hudson, CCL 119B, Turnholti 1983, 165-375 (= PL 91, 1065C-1236C).

Biblia sacra iuxta Vulgatam versionem, praeparavit R. Gryson, Vierte, verbesserte Auflage, Stuttgart 1994.

Biblia Tysiqclecia, wyd. 2, Poznań - Warszawa 1971.

Bruno Carthusianorum, Expositio in Psalmos, PL 152, 637B-1420C.

Callimachus, Aetia. Iambi. Lyric poems. Hecale. Minor epic and elegiac poems. Fragments of epigrams. Fragments of uncertain location, text, translation and notes by C.A. Trypanis, Cambridge (Mass.) - London 1958.

Chrestomathia Straboniana, w: Geopgraphi Graeci Minores, vol. II, s. 529-636.

Cicero, Scripta quae supersunt omnia, fasc. III: De oratore, ed. K. Kumaniecki, Leipzig 1969.

Cosmographia, w: Geographi Latini Minores, s. 71-103.

La „Descriptio mappe mundi” de Hugues de Saint-Victor. Texte inédit avec introduction et commentaire, éd. par P. Gautier Dalché, Collection des Études Augustiniennes. Série Moyen Âge et Temps Modernes [20], Paris 1988.

Dicuilus, Liber de mensura orbis terrae, ed. G. Parthey, Berlin 1870 [reprint: Graz 1969].

Dionysus Halicarnasensis, Antiquitates romanae, ed. C. Jacoby, vol. 1, Lipsiae 1885.

Documenta historica quae ad sanctum Thomam Cantuariensem pertinent, PL 190, 371A-436B. 
Dudo Decanus, De moribus et actis primorum Northmanniae ducum, PL 141, 607B-758D.

Eucherius Lugdunensis, Formulae spiritualis intelligentiae, w: tenże, Formulae spiritualis intelligentiae, Instructiones, Passio agaunensium martyrum, Epistula ad laudem Heremi, rec. C. Wotke, CSEL 31, Pragae - Vindobonae - Lipsiae 1894, 1-62 (= PL 50, 727A-772D).

Eugyppius, Excerpta ex operibus S. Augustini, ed. P. Knoell, CSEL 9/1, Vindobonae 1885 (= PL 62,561D-1088A).

Excerpta eius sphaerae vel continentia (Iulius Honorius), w: Geographi Latni Minores, s. 24-55.

Die Fragmente der Vorsokratiker, hrsg. von H. Diels und W. Kranz, Bd. I, 6. Aufl., Berlin 1951.

Gerhohus Reicherspergensis, Expositio in canticum Habacuc, PL 194, 1027B-1046C.

Gerhohus Reicherspergensis, Expositio in Psalmos (continuatio), PL 194, 9A-998B.

Geographi Graeci Minores, ed. C. Müllerus, vol. 1-2, Parisiis 1882.

Geographi Latini Minores, rec. A. Riese, Heilbronn 1878 [reprint: Hildesheim 1964].

Gervase of Tilbury, Otia imperialia, ed. S.E. Banks \& J.W. Binns, Oxford Medieval Texts, Oxford 2002.

Godefridus Admontensis, Liber de decem oneribus Isaiae, PL 174, 1157D-1210C.

Gregorius Magnus, Homiliae in Ezechielem prophetam, ed. M. Adriaen, CCL 142, Turnholti 1971 (= SCh 327 i $360=$ PL 76, 785A-1072C).

Gregorius Magnus, Moralia in Iob libri XXIII-XXXV, ed. M. Adriaen, CCL 143B, Turnholti 1985 (= PL 76, 249B-782A).

Gregorius Magnus, Super Cantica canticorum expositio, PL 79, 471A-548A.

Guibertus S. Mariae de Novigento, Morialia in Genesin, PL 156, 31C-338C.

Guido, Geographica, w: Itineraria Romana, vol. 2: Ravennatis Anonymi Cosmographia et Guidonis Geographica, ed. J. Schnetz, indicem composuit et adiecit M. Zumschlinge, Itineraria Romana 2, Stutgardiae 1990, s. 111-142.

Guillelmus a Sancto Theodorico, Excerpta ex libris beati Gregorii papae super Cantica canticorum, w: tenże, Opera omnia, pars II, ed. P. Verdeyen, CCCM 87, Turnholti 1987, 392-444 (= PL 180, 441A-474B).

Guillelmus Malmesburiensis $\rightarrow$ Th.D. Pfaff, The „Abbreviatio Amalarii” of William of Malmesbury. Text, RTAM 48 (1981) 128-171.

Haymo Halberstatensis, Expositio in Apocalypsin, PL 117, 937C-1220D.

Hellanicus Lesbius, w: Die Fragmente der griechischen Historiker, Teil I: Genealogie und Mythographie, A: Vorrede. Text. Addenda. Konkordanz, hrsg. von F. Jacoby, Leiden 1957, 104, 5 - 152, 18 (Nr. 4).

Herodotus, Historia, ed. H. Kallenberg, editio altera, vol. 1, Lipsiae 1921.

Hildebertus Cenomanensis, Sermones, PL 171, 343A-964C.

Hildegardis Bingenesis, Epistolae, PL 197, 145A-382C.

Honorius Augustodunensis, Imago mundi, ed. V.I.J. Flint, „Archives d'Histoire Doctrinale et Littéraire du Moyen Âge" 57 (1982) 7-153 (= PL 172, 121A-188C).

Hugo de S. Victore, Miscellanea, PL 177, 469C-900C.

Isidorus Hispalensis, Etymologiae sive Origines, ed. W.M. Lindsay, Scriptorum Classicorum Bibliotheca Oxoniensis, Oxford 1911 (= PL 82, 73C-728C).

Das Marmor Parium, hrsg. und erklärt von F. Jacoby, Berlin 1904.

Martianus Capella, De nuptiis Philologiae et Mercurii, ed. J. Willis, Leipzig 1983.

Orosius, Historia adversus paganos, ed. K. Zangemeister, w: Orosius, Historia adversus paganos. Liber apologeticus, CSEL 5, Wien 1882 [reprint: Hildesheim 1967], 1-564 
(= PL 31, 663B-1174B). Por też Geographi Latni Minores, s. 56-70 (tutaj ks. I, rozdz.

2 - czyli opis ekumeny).

Ovidius, Tristia, w: tenże, [Opera omnia], vol. 3: Tristia, Ibis, Ex Ponto libri, Fasti, ed. R.

Merkel, Lipsiae 1914, 1-102.

Plinius, Naturalis historia, vol. 1: Libri I-VI, rec. C. Mayhoff, Lipsiae 1906.

PLInIUs, Naturalis historia, vol. 2: Libri VII-XV, rec. C. Mayhoff, Lipsiae 1909.

Polybius, Historiae, ed. Th. Büttner-Wobst, vol. 1, editio altera, Lipsiae 1905.

Polybius, Historiae, ed. Th. Büttner-Wobst, vol. 4, Lipsiae 1904.

Pomponius Mela, Chorographia, rec. C. Frick, Stutgardiae 1968.

Ptolemaeus Claudius, Geographia, t. 1-3, ed. C.F.A. Nobbe, Lipsiae 1843-1945 [reprint: Hildesheim 1990].

Quintilianus, Institutio oratoria, vol. 1-2, ed. L. Radermacher, Lipsiae 1965.

Rabanus Maurus, De universo, PL 111, 9A-614B.

Ravennas Anonymus, Cosmographia, w: Itineraria Romana, vol. 2: Ravennatis Anonymi

Cosmographia et Guidonis Geographica, ed. J. Schnetz, indicem composuit et adiecit

M. Zumschlinge, Itineraria Romana 2, Stutgardiae 1990, 1-110.

Rutilius Namatianus, De reditu suo, ed. P. van de Woestijne, Antwerpen - Paris 1936.

Servius Grammaticus, In Vergilii carmina commentarii, vol. 2: Aeneidos librorum VI-XII commentarii, rec. G. Thilo, Lipsiae 1884.

Situs orbis terre vel regionum: Un traité de géographie inédit du haut Moyen Âge (Paris,

B. N. Latin 4841), ed. P. Gautier Dalché, ,Revue d'Histoire des Textes” 12-13 (19821983) 149-179.

Solinus, Collectanea rerum memorabilium, rec. Th. Mommsen, ed. 2, Berolini 1958.

Straвo, Geographica, vol. 1-3, ed. A. Meineke, Lipsiae 1895-1899.

Tacitus, Agricola, w: tenże, Libri qui supersunt, t. 2, fasc. 2: Germania. Agricola. Dialogus de oratoribus, ed. E. Koestermann, Lipsiae 1964, 33-66.

Timaeus Tauromenitanus, w: Die Fragmente der griechischen Historiker, Teil III: Geschichte von Staedten und Voelkern (Horographie und Ethnographie), B: Autoren ueber einzelne Staedte (Laender), hrsg. von F. Jacoby, Leiden 1964, 581, 1 - 658, 24 (Nr. 566).

VArro, Res rusticae, ed. G. Goetz, Lipsiae 1912.

Vergilius, Aeneis, w: Vergilius, Opera, rec. O. Ribbeck, Lipsiae 1910, 99-409.

Willelmus Calculus, Historiae Northmannorum, PL 149, 779A-910A.

Willelmus de Conches, De philosophia mundi, PL 172, 41D-102A (= PL 90, 1127A-1178D).

\section{Opracowania}

Assmann A., Erinnerungsräume. Formen und Wandlungen des kulturellen Gedächtnisses, München 1999.

Atlas. The Bulgarian Lands in the European Cartographic Tradition ( $3^{\text {rd }}-19^{\text {th }}$ Centuries), editors: A. Fol, A. Stamatov, Sofia 2008.

Bagrow L. - Skelton R.A., Meister der Kartographie, 5. Aufl., Frankfurt am Main Berlin 1985.

BAUmgärtner I., Die Welt im kartographischen Blick. Zur Veränderbarkeit mittelalterlicher Weltkarten am Beispiel der Beatustradition vom 10. bis 13. Jahrhundert, w: Der weite Blick des Historikers. Einsichten in Kultur-, Landes- und Stadtgeschichte: Peter Johanek zum 65. Geburtstag, hrsg. von W. Ehbrecht, Köln 2002, 527-549.

Baumgärtner I., Graphische Gestalt und Signifikanz. Europa in den Weltkarten des Beatus von Liébana und des Ranulf Hidgen, w: Europa im Weltbild des Mittelalters. 
Kartographische Konzepte, hrsg. von I. Baumgärtner und H. Kugler, Orbis Mediaevalis 10, Berlin 2008, 81-132.

Baumgärtner I., Visualisierte Weltenräume. Tradition und Innovation in den Weltkarten der Beatustradition des 10. bis 13. Jahrhunderts, w: Tradition, Innovation, Invention. Fortschrittsverweigerung und Fortschrittsbewusstsein im Mittelalter, hrsg. von H.-J. Schmidt, Scrinium Friburgense 18, Berlin - New York 2005, 231-276.

Bernardini P., Gli eroi e le fonti, w: $\Lambda \mathrm{O} \Gamma \mathrm{O} \Sigma$ ПЕPI TH $\Sigma \Sigma \mathrm{AP} \Delta \mathrm{OY} \Sigma$. Le fonti classiche e la Sardegna, Atti del Convegno di Studi - Lanusei, 29 dicembre 1998, a cura di R. Zucca, Roma 2004, 39-62.

Bertrand J.-M., De l'emploi des métaphores descriptives par les géographes de l'Antiquité, „Dialogues d'Histoire Ancienne” 15 (1989) 63-73.

Bertrand J.-M., Sur quelques descriptions antiques de la péninsule italienne, „Mappemonde" 2 (1986) 26-30.

Bevan W.L. - Phillott H.W., Mediaeval Geography: An Essays in Illustration of the Hereford Mappa Mundi, London 1873 [reprint: Amsterdam 1969].

Bılı́́ski B., De Graeciae in Pliniana descriptio (N.H. IV 1-32) sinibus quaestiones, „Eos” 41 (1940-1946) fasc. 1, 123-155.

Birkholz D., Hereford Maps, Hereford lives. Biography and cartography in an English cathedral city, w: Mapping Medieval Geographies, s. 225-249.

Buum H., Die antike Mnemotechnik, Spudasmata 15, Hildesheim 1969.

Bouloux N., Culture et savoirs géographiques en Italie au XIV siècle, Terrarum Orbis 2, Turnhout 2002.

Bouloux N., L'espace habité, w: La Terre. Connaissance, représentations, mesure au Moyen Âge, s. 259-441.

Brincken A.-D. von den, Die Ausbildung konventioneller Zeichen und Farbgebungen in der Universalkartographie des Mittelalters, „Archiv für Diplomatik. Schriftgeschichte, Siegel- und Wappenkunde" 16 (1970) 325-349 (= taż, Studien zur Universalkartographie des Mittelalters, s. 112-136).

Brincken A.-D. von den, Der vierte Erdteil in der Kartographie des Hochmittelalters, $\mathrm{w}$ : Reisen in reale und mythische Ferne. Reisenliteratur in Mittelalter und Renaissance, hrsg. von P. Wunderli, Studia Humaniora 22, Düsseldorf 1993, 16-34 (= taż, Studien zur Universalkartographie des Mittelalters, s. 415-443).

Brincken A.-D. von den, Fines Terrae. Die Enden der Erde und der vierte Kontinent auf mittelalterlichen Weltkarten, Monumenta Germaniae Historica. Schriften 36, Hannover 1992.

Brincken A.-D. von den, Gyrus und Spera - Relikte griechischer Geographie im Weltbild der Frühscholastik (Aufgezeigt an fünf lateinischen Weltkarten des beginnenden 12. Jahrhunderts), „Sudhoffs Archiv” 73 (1989) Heft 2, 129-144 (= taż, Studien zur Universalkartographie des Mittelalters, s. 345-366).

Brincken A.-D. von den, Kartographische Quellen Welt-, See- und Regionalkarten, Typologie des Sources du Moyen Âge Occidental 51, Turnhout 1988.

Brincken A.-D. von den, Mappe del Medio Evo: Mappe del cielo e della terra, w: Cieli e terre nei secoli XI-XII. Orizzonti, percezioni, rapporti, Atti della tredicesima Settimana internazionale di studi, Mendola, 22-26 agosto 1995, Miscellanea del Centro di Studi Medioevali 15, Milano 1998, 31-50 (= taż, Studien zur Universalkartographie des Mittelalters, s. 533-551)

Brincken A.-D. von den, Monumental Legends on Medieval Manuscript Maps. Notes on designed capital letters on maps of large size (demonstrated from the Problem of 
dating the Vercelli Map, thirteenth century), „Imago Mundi” 42 (1990) 9-25 (= taż, Studien zur Universalkartographie des Mittelalters, s. 375-399).

BrincKen A.-D. von den, Romazentrische Weltdarstellung um die erste Jahrtausendwende, w: Kaiserin Theophanu: Begegnung des Ostens und Westens um die Wende des ersten Jahrtausends. Gedenkschrift des Kölner Schnütgen-Museums zum 1000. Todesjahr der Kaiserin, hrsg. von A. von Euw und P. Schreiner, Bd. 1, Köln 1991, 401-411.

BRINCKen A.-D. von den, Spuren Nubiens in der abendländischen Universalkartographie im 12. bis 15. Jahrhundert, w: Vom ,Troglodytenland” ins Reich der Scheherazade. Archäologie, Kunst und Religion zwischen Okzident und Orient. Festschrift für Piotr O. Scholz zum 70. Geburtstag, hrsg. von M. Długosz, Berlin 2014, 43-51.

Brincken A.-D. von den, Studien zur Universalkartographie des Mittelalters, hrsg. von Th. Szabó, Veröffentlichungen des Max-Planck-Instituts für Geschichte 229, Göttingen 2008.

Bronder B., Das Bild der Schöpfung und Neuschöpfung der Welt als orbis quadratus, „Frühmittelalterliche Studien” 6 (1972) 188-210.

Brotton J., Stynne mapy, red. naukowa L. Szaniawska, Warszawa 2016.

BRuss J.S., Lessons from Ceos. Written and spoken word of Callimachus, w: Callimachus II, ed. by M.A. Harder - R.F. Regtuit - G.C. Walker, Hellenistica Groningiana 7, Leuven 2004, 49-70.

CAdiou F., Géographie et „,pompa triumphalis” à Rome, „Geographia Antiqua” 19 (2010) 141-150.

Cattaneo A., Fra Mauro's Mappa Mundi and Fifteenth-Century Venice, Orbis Terrarum 8, Turnhout 2011.

Chekin L.S., Northern Eurasia in Medieval Cartography. Inventory, Text, Translation, and Commentary, Terrarum Orbis 4, Turnhout 2006.

Chiai G.F., Il nome della Sardegna e della Sicilia sulle rote dei Fenici e dei Greci in età arcaica. Analisi di una tradizione storico-letteraria, „Rivista di Studi Fenici” 30 (2002) $\mathrm{nr}$ 2, 125-146.

Chocheyras J., Fin des terres et fin des temps d'Hésychius (Ve siècle) à Béatus (VIII siècle), w: The Use and Abuse of Eschatology in the Middle Ages, ed. by W. Verbeke - D. Verhelst - A. Welkenhuysen, Mediaevalia Lovaniensia I/15, Leuven 1988, 72-81.

Clausberg K., Scheibe, Rad, Zifferblatt. Grenzübergänge zwischen Weltkarten und Weltbildern, w: Ein Weltbild vor Columbus, s. 260-315.

Coolman B.T., The Theology of Hugh of St. Victor. An Interpretation, Cambridge 2010.

Cortambert E., Quelques-uns des plus anciens monuments géographique du Moyen Âge conservés à la Bibliothèque Nationale, „Bulletin de la Société de Géographie” 6 Ser., 14 (1877) 337-363.

Delano-Smith C., Signs on Printed Topographical Maps, ca. 1470 - ca. 1640, w: The History of Cartography, vol. 3, part 1: Cartography in the European Renaissance, ed. D. Woodward, Chicago 2007, 528-590.

De Sensis Sestito G., Italo, Italía, Italioti: alle origini di una nozione, w: Unità multiple.

Centocinquant'anni? Unità? Italia?, a cura di G. De Sensis Sestito - M. Petrusewicz, Saggi 347, Soveria Mannelli 2014, 53-92.

Destombes M., Mappemondes A.D. 1200-1500. Catalogue prepare par la Commission des Cartes Anciennes de l'Union Géographique Internationale, Monumenta Cartographica Vetustioris Aevi I, Amsterdam 1964.

Di Cesare M., Studien zu Paulinus Venetus „,De mapa mundi”, MGH. Studien und Texte 58, Wiesbaden 2015.

Dion R., Rhenus bicornis, „Revue des Études Latines” 42 (1964) 469-499. 
Dürst A., Manuskriptkarte von West-Europa, um 1200, „Cartographica Helvetica” 20 (1999) 35-38.

Die Ebstorfer Weltkarte. Interdisziplinäres Colloquium 1988, hrsg. von H. Kugler-E. Michael, Acta Humaniora, Weinheim 1991.

Die Ebstorfer Weltkarte. Kommentierte Neuausgabe in zwei Bänden. Band I: Atlas; Band II: Untersuchungen und Kommentar, hrsg. von H. Kugler, unter Mitarbeit von S. Glauch und A. Willing, Berlin 2007.

Edson E. - Savage-Smith E., Medieval Views of the Cosmos. Picturing the Universe in the Christian and Islamic Middle Ages, with a forword by T. Jones, Oxford 2004.

Edson E. - Savage-Smith E. - Brincken A.-D. von den, Der mittelalterliche Kosmos. Karten der christlichen und islamischen Welt, Aus dem Englischen von T. Ganschow, 2. Aufl., Darmstadt 2011.

Egry A. de, Um estudo do Apocalipse de Lorvão e a sua relação com as ilustrações medievais do Apocalipse, Publicação Fundação Calouste Gulbenkian, Lisboa 1972.

Englisch B., Ordo orbis terrae. Die Weltsicht in den Mappae mundi der frühen und hohen Mittelalters, Orbis Mediaevalis 3, Berlin 2002.

Falchetta P., Frau Mauro's World Map, Terrarum Orbis 5, Turnhout 2006.

Ferrara G., Della voce „Scutula”. Nota di semantica latina, Milano 1905.

Ferrara G., La forma della Britannia secondo la testimonianza di Tacito: nota, Milano 1904.

FISCHER T., Sammlung mittelalterlicher Welt- und Seekarten italienischen Ursprungs und aus italienischen Bibliotheken und Archiven, Venedig 1886 [reprint: Amsterdam 1961].

Forstner D., Świat symboliki chrześcijańskiej. Leksykon, tłum. W. Zakrzewska - P. Pachciarek - R. Turzyński, Warszawa 2001.

Foxell S., Mapping England, London 2008.

Frenschrowski M., Offenbarung und Epiphanie, 2. Bd.: Die verborgene Epiphanie in Spätantike und frühen Christentum, Wissenschaftliche Untersuchungen zum Neuen Testament II/80, Tübingen 1997.

Galichian R., Countries south of the Caucasus in Medieval Maps. Armenia, Georgia and Azerbaijan, London 2007.

García-Aráez H., Los mapamundis de los Beatos (2 ${ }^{\mathrm{a}}$ parte). Nomenclator y conclusiones, „Miscelánea Medieval Murciana” 19-20 (1995-1996) 97-128.

Gautier Dalché P., De la glose à la contemplation. Place et fonction de la carte dans les manuscrits du haut Moyen Âge, w: Testo e imagine nell'Alto Medioevo, 15-21 aprile 1993, t. 2, Settimane di Studio del Centro Italiano di Studi sull'Alto Medioevo 41/2, Spoleto 1994, 693-771.

Gautier Dalché P., La „Descriptio mappe mundi” de Hugues de Saint-Victor. Texte inédit avec introduction et commentaire, Paris 1988.

Gautier Dalché P., La Géographie de Ptolémée en Occident (IVE-XVIe siècle), Terrarum Orbis 9, Turnhout 2009.

Gautier Dalché P., La Terre dans le cosmos, w: La Terre. Connaissance, représentations, mesure au Moyen Âge, s. 161-257. GAUTIER DALché P., Mappae mundi antérieures au $X I I I^{e}$ siècle dans les manuscrits latins de la Bibliothèque Nationale de France, „Scriptorium" 52 (1998) 102-161. Gautier Dalché P., Mappemonde dessinée à Fleury, w: Autour de Gerbert d'Aurillac le pape de l'an mil. Album de documents commentés, réunis sous la direction d'O. Guyotjeannin - M. Poulle, Matériaux pour l'Histoire publiés par École des Chartes 1, Paris 1996, 2-6. 
Gautier Dalché P., Notes sur la „, carte de Théodose II” et sur la „, mappemonde de Théodulfe d 'Orléans”, „Geographia Antiqua” 3 (1994-1995) 91-108.

Gedächtnislehren und Gedächtniskünste in Antike und Frühmittelalter (5. Jahrhundert v. Chr. bis 9. Jahrhundert n. Chr.). Dokumentensammlung mit Übersetzung, Kommentar und Nachwort, hrsg. von J.J. Berns, unter Mitarbeit von R.G. Czapla - S. Arend, Tübingen 2003.

Glorie F., Mappa mundi (e codice Vatic. Lat. 6018), w: Itineraria et alia geographica, CCL 175, Turnholti 1965, 455-466.

Glorie F., Mappa mundi e codice Albigensi 29, w: Itineraria et alia geographica, CCL 175, Turnholti 1965, 467-469.

Goldmann S., Statt Totenklage Gedächtnis. Zur Erfindung der Mnemotechnik durch Simonides von Keos, „Poetica” 21 (1989) 43-66.

Gorissen F., Rhenus bicornis, w: Brückenschlag am Niederrhein: Land und Mensch am Niederrhein. Eine kulturgeographische Festschrift zur Einweihung der Rheinbrücke Kleve-Emmerich am 3.9.1965, hrsg. von J. Ruland, Niederrheinisches Jahrbuch 9, Düsseldorf 1965, 79-164.

Gormans A., Geometria et ars memorativa. Studien zur Bedeutung von Kreis und Quadrat als Bestandteile mittelalterlicher Mnemonik und ihrer Wirkungsgeschichte an ausgewählten Beispielen, Doktorarbeit. Philosophische Fakultät der Rheinisch-Westfälischen Technischen Hochschule Aaachen, 1999 (praca ta jest w całości dostępna w internecie pod adresem: http:/darwin.bth.rwth.aachen.de/opus3/ volltexte/2003/551/ pdf/03_081pdf [data dostępu: 10 IX 2017]).

Goss J., KartenKunst. Die Geschichte der Kartographie, übers. aus dem Engl. von E. Heinemann - R. Tiffert, Braunschweig 1994.

Grosjean G. - Kinauer R., Kartenkunst und Kartentechnik vom Altertum bis zum Barock, Bern - Stuttgart 1970.

Gustawicz B., Zarys historyczny sposobów kreślenia kart geograficznych, w: Sprawozdanie dyrektora C. K. gimnazyum nowodworskiego św. Anny w Krakowie za rok szkolny 1882, Kraków 1882, 1-63 [odbitka: Kraków 1882].

Hahn-Woernle B., Die Ebstorfer Weltkarte und Fortuna Rotis-Vorstellungen, w: Ein Weltbild vor Columbus, s. 185-201.

Hajdu H., Das mnemotechnische Schrifttum des Mittelalters, Budapest 1936.

Hallberg I., L'Extrème Orient dans la littérature et la cartographie de l'Occident des $X I I I^{e}, X I V^{E}$ et XV $V^{e}$ siècles. Études sur l'histoire de la géographie, Göteborg 1906.

HeEren A.H.L., Explicatio planiglobii, orbis terrarvm faciem exhibentis, ante medivm saecvlvm XV. svmma arte confecti; Mvsei Borgiani Velitris; agitantvr simvl de historia mapparvm geographicarvm recte institvenda consilia, „Commentationes Societatis Regiae Scientiarum Gottingensis Classis Historicae et Philologicae” 16 (1808) 250-284.

Hiatт A., The Map of Macrobius before 1100, „Imago Mundi” 59 (2008) nr 2, 149-176.

Hill Th.D., The Tropological Context of Heat and Cold Imagery in Anglosaxon Poetry, „Neuphilologische Mitteilungen” 69 (1968) nr 4, 522-532.

Hoogvliet M., Pictura et scriptura. Textes, images et herméneutique des mappae mundi (XIII ${ }^{e}-X V I^{e}$ siècle), Orbis Terrarum 7, Turnhout 2007.

IwańczaK W., Borders and Borderlines in Medieval Cartography, w: Frontiers in the Middle Ages. Proceedings of the Third European Congress of Medieval Studies, Jyväskylä, 10-14 June 2003, ed. by O. Merisolo \& P. Pahta, Textes et Études du Moyen Âges 35, Louvain-la-Neuve 2006, 661-672. 
Der Katalanische Weltaltlas vom Jahre 1375 nach dem in der Bibliothèque Nationale, Paris, verwahrten Original farbig wieder gegeben, mit einer Einführung und Übersetzungen von H.-Ch. Freiesleben, Quellen und Forschungen zur Geschichte der Geographie und der Reisen 11, Stuttgart 1977.

Kobielus S., Krzyż Chrystusa. Od znaku i figury do symbolu i metafory, wyd. 2, Tyniec 2011.

Kochanek P., Anatole-Dysis-Arktos-Mesembria, VoxP 28 (2008) t. 52/1, 471-488.

KochaneK P., Boska prawica a europocentryzm, w: Wiedza między słowem a obrazem, redakcja: M. Zemła - A. Jabłoński - J. Szymczyk, Studia nad Wiedzą 3, Lublin 2010, 159-188.

Kochanek P., Cesarstwo Bizantyńskie w kartografii Zachodu około roku 1000, „Teka Komisji Historycznej PAN" 12 (2015) 7-34.

Kochanek P., Die Vorstellung vom Norden und der Eurozentrismus. Eine Auswertung der patristischen und mittelalterlichen Literatur, Veröffentlichungen des Instituts für Europäische Geschichte Mainz. Abteilung für Abendländische Religionsgeschichte 205, Mainz 2004.

KRETSCHMER K., Eine neue mittelalterliche Weltkarte der vatikanischen Bibliothek, „Zeitschrift der Gesellschaft für Erdkunde zu Berlin" 26 (1891) 371-406.

KochANEK P., Etnomedycyna hippokratejska a geopolityczna myśl grecka $w$ V w. p.n.e., $\mathrm{w}$ : Kontrowersje dyskursywne. Między wiedza specjalistyczna a praktyka społeczna, red. A. Jabłoński - J. Szymczyk - M. Zemła, Studia nad Wiedzą 4, Lublin 2012, $27-56$.

КохАнек П., Генезис схематического образа побережья Чёрного моря на картах XV века, „Bulgarian Historical Review” 41 (2013) nr 3-4, 3-32.

KochaneK P., Iluzja schematów choro- $i$ topograficznych jako baza mnemotechnicznej portolany $w$ starożytności, w: Tworzenie iluzji społecznej-wiedza $w$ sferze publicznej, red. J. Szymczyk - M. Zemła - A. Jabłoński, Studia nad Wiedzą 5, Lublin 2012, 73-126.

KochaneK P., Kartografia antropomorficzna a europejska ideologia hierarchii narodów, w: Kreowanie społeczeństwa niewiedzy, red. A. Jabłoński - J. Szymczyk - M. Zemła, Studia nad Wiedzą 7, Lublin 2015, 101-159.

KochaneK P., Klauzura północno-wschodniej Azji na mapach średniowiecznych i wczesnonowożytnych, VoxP 36 (2016) t. 65, 211-344.

KochaneK P., Rekonstrukcje globusa Kratesa z Mallos $w$ dwóch polskich podręcznikach historii geografii, „Acta Mediaevalia” 20 (2007) 139-152.

Kochanek P., ,,Rozesłanie Apostołów” na mapie Beatusa z Burgo de Osma, w: Fructus Spiritus est Caritas, Księga Jubileuszowa ofiarowana Księdzu Profesorowi Franciszkowi Drqczkowskiemu z okazji siedemdziesiatej rocznicy urodzin, czterdziestolecia święceń kapłańskich i trzydziestopięciolecia pracy naukowej, red. M. Wysocki, Lublin 2011, 703-745.

KochaneK P., Schematy ekumeny $w$ literaturze patrystycznej $w$ kontekście klasycznych schematów zamieszkałej Ziemi, VoxP 30 (2010) t. 55, 307-340.

KochaneK P., Winiety metropolii Pentarchii na mapach średniowiecznych $i$ wczesnonowożytnych, VoxP 34 (2014) t. 62, 213-296.

Kochanek P., Wspótczesne rekonstrukcje globusa Kratesa z Mallos, w: Archiva temporum testes. Źródła historyczne jako podstawa pracy badacza dziejów, Księga pamiątkowa ofiarowana Profesorowi Stanisławowi Olczakowi, red. G. Bujak - T. Nowicki - P. Siwicki, TN KUL Prace Wydziału Historyczno-Filologicznego 143, Lublin 2008, 247-260. 
Kretschmer K., Die Entdeckung Amerika's in ihrer Bedeutung für die Geschichte des Weltbildes. Atlas der Festschrift des Gesellschaft für Erdkunde zu Berlin zur vierhundertjährigen Feier der Entdeckung Amerika's, Berlin - Leipzig 1892.

Kretschmer K., Die Katalanische Weltkarte der Biblioteca Estense zu Modena, „Zeitschrift der Gesellschaft für Erdkunde zu Berlin" 32 (1897) 65-111 i 191-218.

Kupfer M., Reflections in the Ebstorf Map. Cartography, Theology and dilectio speculationis, w: Mapping Medieval Geographies, s. 100-126.

Külzer A. , Die Weltkarte des ,,Wiener Kompendium”. Der Codex Vindobonensis 505 saec. XIV und seine Karte des byzantinischen Reiches, „Biblos” 45 (1996) 225-238.

LAharie M., Une cartographie «à la folie»: Le journal d'Opicinus de Canistris (Bibliothèque Apostolique Vaticane, Cod. Vat. Lat. 6435), „Mélanges de l'École Française de Rome. Moyen Âge" 119 (2007) nr 2, 361-399.

LAHARIE M., Le journal singulier d'Opicinus de Canistris (1337 - vers 1341): Vaticanus Latinus 6435, t. 1-2, Studi e Testi 447-448, Città del Vaticano 2008.

La Roncière M. de, Mollat du Jourdin M., Portulane. Seekarten vom 13. bis zum 17. Jahrhundert, übers. von R. Beyer, München 1984.

Lecoq D., La Mappemonde de „, Liber Floridus” ou la Vision du Monde de Lambert de Saint-Omer, „Imago Mundi” 39 (1987) 9-49.

Lecoq D., La mappemonde d'Henri de Mayence ou l'image du monde au XII siècle, $\mathrm{w}$ : Iconographie médiévale. Image, texte, contexte, sous la dir. de Gaston DuchetSuchaux, Paris 1990, 155-207.

Lelewel J., Épilog de la géographie du Moyen Âge, Bruxelles 1857 [reprint: Amsterdam 1966].

Lelewel J., Géographie du Moyen Age, t. 2, Bruxelles 1852 [reprint: Amsterdam 1966].

Lester T., Da Vinci's Ghost: Genius, Obsession, and How Leonardo Created the World of His Own Image, New York 2012.

Liebeschütz H., Das allegorische Weltbild der heiligen Hildegard von Bingen, Studien der Bibliothek Warburg 16, Leipzig - Berlin 1930 [reprint: Darmstadt 1964].

Majewsin T., Mnemotechnika, w: Modi memoranda. Leksykon kultury pamięci, red. M. Saryusz-Wolska - R. Traba - J. Kalicka, Warszawa 2017, 240-246.

Mapamundi. Der katalanische Weltatlas vom Jahre 1375, hrsg. und kommentiert von G. Grosjean, Dietikon - Zürich 1977.

Mapping Medieval Geographies. Geographical Encounters in the Latin West and Beyond, 300-1600, ed. by K.D. Lilley, Cambridge 2013.

Marinelli G., Gog e Magog. Leggenda geografica, „Cosmos” 7 (1882-1883) 155-180 i 199-207.

Menéndez-Pidal G., Mozárabes y Asturianos en la cultura de la alta Edad Media en relación especial con la historia de los conocimientos geográficos, „Boletin de la Real Academia de la Historia” 134 (1954) 137-291.

Milani C., Sardinia in testi latini medievali, „Il Nome nel Testo” 11 (2009) 67-72.

Miller K., Mappaemundi. Die ältesten Weltkarten, I. Heft: Die Weltkarte des Beatus (776 n. Chr.), Stuttgart 1895.

Miller K., Mappaemundi. Die ältesten Weltkarten, III. Heft: Die kleineren Weltkarten, Stuttgart 1895.

Miller K., Mappaemundi. Die ältesten Weltkarten, IV. Heft: Die Herefordkarte, Stuttgart 1896.

Miller K., Mappaemundi. Die ältesten Weltkarten, V. Heft: Die Ebstorfkarte, Stuttgart 1896. 
Miller K., Mappaemundi. Die ältesten Weltkarten, VI. Heft: Rekonstruierte Karten, Stuttgart 1898.

Miller K., Die Peutingerische Tafel oder Weltkarte des Castorius, Stuttgart 1916.

Monda S., La „, Cosmographia” di Giulio Onorio. Un exceptum scolastico tardo-antico, Roma 2008.

Nicolet C., Gautier Dalché P., Les „,quatre sages” de Jules César et la „,mesure du monde” selon Julius Honorius: réalité antiique et tradition médiévale, „Journal des Savants" 1986 157-218.

Nöтн W., Medieval Maps: Hybrid Ideographic and Geographic Sign Systems, w: Herrschaft verorten. Politische Kartographie im Mittelalter und in der frühen Neuzeit, hrsg. von I. Baumgärtner und M. Stercken, Medienwandel - Medienwechsel - Medienwissen 19, Zürich 2012, 335-353.

Nussbaum O., Die Bewertung von rechts und links in der römischen Liturgie, JbAC 5 (1962) 158-171.

O'Loughlin Th., An Early Thirteenth-Century Map in Dublin: A Window into the World of Giraldus Cambrensis, „Imago Mundi” 51 (1999) 24-39.

Östenberg I., Staging the World. Spoils, Captives, and Representations in Roman Triumphal Procession, Oxford Studies in Ancient Culture, Oxford - New York 2009.

Post L.A., Ancient Memory Systems, ,The Classical Weekly” 25 (1932) nr 14, 105-110.

Prontera F., Imagines Italiae. Sulle più antiche visualizzazioni e rappresentazioni geografiche dell'Italia, „Athenaeum” 64 (1986) 295-320.

РАмм Б.Я., Новонайденный ленинградский экземпляр макробиевой карты и его научное значение, „Ученые Записки Ленинградского Государственного Университета", Серия Исторических Наук, 18 (1951) nr 130, 250-270.

Reichert F., Das Bild der Welt im Mittelalter, Darmstadt 2013.

Riese A., Rhenus bicornis, „Römisch-germanisches Korrespondenzblatt” 9 (1916) 77-78.

RöGER J., Die Bergzeichnung auf den älteren Karten. Ihr Verhältnis zur darstellenden Kunst, München 1910.

SÁenz-López Pérez S., Peregrinatio in stabilitate: transformación de un mapa de los Beatos en herramienta de peregrinación espiritual, „Anales de Historia del Arte”, volumen extraordinario, 2011, 317-334.

Salomon R., Opicinus de Canistris. Weltbild und Bekenntnisse eines avignonesischen Klerikers des 14. Jahrhunderts, 1. Bd.: Textband, 2. Bd.: Tafelband, Studies of the Warburg Institute I A-B, London 1936.

SÁnchez-Albornoz C., La España christiana de los siglos VIII al. XI, vol. 1: El reino Astur-Leonés (722-1037): Sociedad, economía, gobierno, cultura y vida, Historia de España 7/1, Madrid 1980.

SAntARem M.F. le Vicomte de, Essai sur l'histoire de la cosmographie et de la cartographie pendant le Moyen-Âge, t. 2-3, Paris 1850-1852.

Scafi A, Mapping Paradise. A History of Heaven on Earth, Chicago 2006.

SCAFI A., Maps of Paradise, London 2013.

Schmidt-Dengler W., Die ,, aula memoriae” in den Konfessionen des heiligen Augustin, REAug 14 (1968) nr 1-2, 69-89.

SchneIder U., Die Macht der Karten. Eine Geschichte der Kartographie vom Mittelalter bis heute, 3. Aufl., Darmstadt 2012.

Schöller B., Transfer of Knowledge: Mappa Mundi Between Texts and Images, „Peregrinations" 4 (2013) nr 1, 42-55.

Schüler C.J., Die Geschichte der Kartographie, Paris 2010. 
Sijmons A.H. - Wallis H., Atlas de Santarem. Fascimile of the final edition 1849. Explanatory notes, Amsterdam 1985.

Simondon M., La mémoire et l'oubli dans la pensée grecque jusqu'à la fin du Viè siècle avant J.-C. Psychologie archaïque, mythes et doctrines, Paris 1982.

Slater W.J., Simonides'House, „Phoenix” 26 (1972) nr 3, 232-240.

Small J.P., Wax tablets of the mind. Cognitive studies of memory and literacy in classical antiquity, London 1997.

Sommerbrodt E., Die Ebstorfer Weltkarte, [II. Teil: Text], Hannover 1891.

Spallone M., La „Cosmographia” di Iulius Honorius e Cassiodoro, „Segno e Testo” 1 (2003) 129-181.

Sprigath G.K., Das Dictum des Simonides, „Poetica” 36 (2004) 243-280.

Средневековье въ его памятникахъ: сборникъ переводовъ, подъ редакціей Д.Н. Егорова, Москва 1913.

Staszewski J., Środowisko geograficzne w nauce antycznej, „Zeszyty Geograficzne Wyższej Szkoły Pedagogicznej w Gdańsku” 2 (1960) 7-43.

Strzelczy J. Gerwazy z Tilbury. Studium z dziejów uczoności geograficznej w średniowieczu, Monografie z Dziejów Nauki i Techniki 66, Wrocław - Warszawa 1970.

Tabula Peutingeriana: Codex Vindobonensis 324, [1:] Vollständige Faksimile-Ausgabe im Originalformat, hrsg. von E. Weber, Graz 1976.

Tabula Peutingeriana. Die einzige Weltkarte aus der Antike, eingel. und kommentiert von M. Rathmann, 2. Aufl., Darmstadt 2017.

La Terre. Connaissance, représentations, mesure au Moyen Âge, sous la dir. de P. Gautier Dalché, L'Atelier du Médiéviste 13, Turnhout 2013.

Uhden R., Die Weltkarte des Isidorus von Sevilla, „Mnemosyne” series III, 3 (1936) 1-28.

Uhden R., Die Weltkarte des Martianus Capella, „Mnemosyne” series III, 3 (1936) 97-124.

Vagnon E., Cartographie et Représentations de l'Orient méditerranéen en Occident (du milieu du XIII à la fin du XV siècle), Orbis Terrarum 11, Turnhout 2013.

Van Duzer Ch. - Sáenz-López Pérez S., Tres filii Noe diviserunt orbem post diluvium: The World Map in British Library Add. Ms. 37049, „Word and Image” 26 (2010) nr 1, 21-39.

VÁzquez de Parga L., Un mapa desconocido de la serie de los «Beatos», w: Actas del Simposio para el estudio de los códices del «Comenatario al Apocalipsis» del Beato de Liébana, t. 1, Madrid 1978, 271-278.

Vesconte P(ietro), Seekarten, Mit einem Geleitwort von O. Mazal. Einführung von L. Pagani, Würzburg 1978.

Le Vicomte de Santarem $\rightarrow$ Santarem

Vidier A., La mappemonde de Théodulf et la mappemonde de Ripoll (IXe-XIe siècle), „Bulletin de Géographie Historique et Descriptive” 26 (1911) 285-313.

Volkmann L., Ars Memorativa, „Jahrbuch der kunsthistorischen Sammlungen in Wien” N.F. 3 (1929) 111-200.

Weeda L. - Poel M. van der, Vergil and the Batavians (Aeneid 8.727), „Mnemosyne” 67 (2014) 588-612.

Weinrich H., Lethe. Kunst und Kritik des Vergessens, 2. Aufl., München 1997.

Ein Weltbild vor Columbus. Die Ebstorfer Weltkarte. Interdisziplinäres Colloquium 1988, hrsg. von H. Kugler - E. Michael, Acta Humaniora, Weinheim 1991.

Wendt J.A., Skarby kartografii, red. naukowa L. Szaniawska, Warszawa 2013.

Westrem S.D., Geography and Travel, w: A Companion to Chaucer, ed. by P. Brown, Blackwell Companions to Literature and Culture [6], Oxford 2000, 195-271. 
Westrem S.D., The Hereford Map. A Transcription and Translation of the Legends with Commentary, Terrarum Orbis 1, Turnhout 2001.

Whittington K., Body-Worlds. Opicinus de Canistris and the Medieval Cartographic Imagination, Studies and Texts 186, Toronto 2014.

Wilamowitz-Moellendorff U. von, Sapho und Simonides. Untersuchungen über griechische Lyriker, Berlin 1913.

Wilke J., Die Ebstorfer Weltkarte, I: Textband, II: Tafelband, Veröffentlichungen des Instituts für Historische Landesforschung der Universität Göttingen 39, Bielefeld 2001.

Williams J., Isidore, Orosius and the Beatus Map, „Imago Mundi” 49 (1997) 7-32.

Winckler K., Die Alpen im Frühmittelalter. Die Geschichte eines Raumes in den Jahren 500 bis 800, Wien 2012.

Wolf A., Ikonologie der Ebstorfer Weltkarte und politische Situation des Jahres 1239. Zum Weltbild des Gervasius von Tilbury am welfischen Hofe, w: Ein Weltbild vor Columbus, s. 54-119.

Wolf B., Jerusalem und Rom: Mitte, Nabel - Zentrum, Haupt. Die Metaphern „Umbilicus mundi" "und ,Caput mundi" in den Weltbildern der Antike und des Abendlands bis in die Zeit der Ebstorfer Weltkarte, Bern 2010.

Wutтke H., Die Karten der seefahrenden Völker Südeuropas bis zum ersten Druck der Erdbeschreibung des Ptolemäus. Zur Geschichte der Erdkunde im letzten Drittel des Mittelalters, Dresden 1871 [reprint: Amsterdam 1961].

Yates F.A., Gedächtnis und Erinnern. Mnemotechnik von Aristoteles bis Shakespeare, übers. von A. Schweikhart, Weinheim 1990.

Zieliński T, Grecja niepodległa, Warszawa 1958.

Zurla P., Il mappamondo di Fra Mauro Camaldolese, Venezia 1806.

\section{Netografia}

http://bvmm.irht.cnrs.fr/ consult/consult.php?reproductionId=7143 [data dostępu: 18 IX 2017].

http://darwin.bth.rwth.aachen.de/opus3/volltexte/2003/551/pdf/03_081pdf [data dostępu: 10 IX 2017].

http://gallica.bnf.fr/ark:/12148/btv1b55002483j/f25.item [data dostępu: 13 IX 2017].

http://litteravisigothica.com/codex-of-the-month-viii-madrid-real-academia-de-lahistoria-cod-76/ [data dostępu: 14 IX 2017].

https://en.wikipedia.org/wiki/History_of_Cagliari [data dostępu: 13 IX 2017].

www.atlantedellarteitaliana.com/artwork-4777.html [data dostępu: 17 VIII 2014].

www.uni-lueneburg.de/hyperimage/EbsKart/start.html [data dostępu: 13 IX 2017]. 
